Aus dem Department für Nutzpflanzenwissenschaften der Georg-August-Universität Göttingen

-Abteilung Pflanzenbau-

\title{
Einfluss von Aussaatstärke, Bodenbearbeitung und Anbaumuster auf den Ertrag von Erbsen-Hafer-Gemengen
}

\author{
Dissertation \\ zur Erlangung des Doktorgrades \\ der Fakultät für Agrarwissenschaften \\ der Georg-August-Universität Göttingen
}

vorgelegt von

Angelika Neumann

aus Meschede

Göttingen, im Februar 2010 
D 7

1. Referent: Prof. Dr. R. Rauber

2. Referent: Prof. Dr. J. Isselstein

Tag der mündlichen Prüfung: 28. Januar 2010 


\section{Inhaltsverzeichnis}

$1 \quad$ Einleitung

1.1 Problemstellung 1

1.2 Ziele 5

1.3 Literatur 6

2 Effects of crop density and tillage system on grain yield and $\mathrm{N}$ uptake from soil and atmosphere of sole and intercropped pea and oat

2.1 Abstract 9

2.2 Introduction 11

2.3 Material and Methods 12

2.4 Results 16

2.5 Discussion 24

2.6 Conclusion 28

2.7 References 29

3 Evaluation of yield-density relationships and optimization of interop compositions of field-grown pea-oat intercrops using the replacement series and the response surface design

3.1 Abstract 33

3.2 Introduction 35

3.3 Material and Methods 36

3.4 Results 42

3.5 Discussion 51

3.6 Conclusion 56

$\begin{array}{lll}3.7 & \text { References } & 57\end{array}$

4 Abschließende Diskussion

4.1 Aussaatstärke 61

4.2 Bodenbearbeitung 69

$\begin{array}{lll}4.3 & \text { Anbaumuster } & 72\end{array}$

4.4 Ausblick 79

4.5 Literatur 82

$5 \quad$ Zusammenfassung / Summary

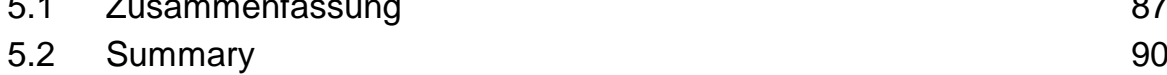




\section{Tabellenverzeichnis}

Table 2.1 Grain yields (Mg ha $\left.{ }^{-1}\right)$ of sole cropped pea and oat with various seed densities (means for both tillage systems)

Table 2.2 Grain yields ( $\mathrm{Mg} \mathrm{ha}^{-1}$ ) of intercropped (i) pea, intercropped (i) oat and the sum of intercropped (i) pea and oat with the respective seed densities(means for both tillage systems)

Table 2.3 Nitrogen content in the grain (\%) of sole (s) and intercropped (i) pea and oat for the average of all pea and oat densities in conventional (CT) and minimal (MT) tillage systems

Table 2.4 Total amount of nitrogen in grain $\left(\mathrm{kg} \mathrm{N} \mathrm{ha}^{-1}\right)$ accumulated by intercropped pea and oat in various mixture combinations (means for both tillage systems)

Table 3.1 Shoot and grain yields as well as amounts of $\mathrm{N}$ in grain of sole cropped pea $\left(\mathrm{P}_{\mathrm{s}}\right)$ and oat $\left(\mathrm{O}_{\mathrm{s}}\right)$, intercroppedpea $\left(\mathrm{P}_{\mathrm{i}}\right)$ and oat $\left(\mathrm{O}_{\mathrm{i}}\right)$ and the sum of intercropped pea and oat $\left(\mathrm{P}_{\mathrm{i}}+\mathrm{O}_{\mathrm{i}}\right)$ in the means of all densities from 40 to 80 pea seeds $\mathrm{m}^{-2}$ and 38 to 300 oat seeds $\mathrm{m}^{-2}$

Table 3.2 Regression coefficients $(r)$ and crowding coefficients $\left(k_{\mathrm{po}}, \mathrm{k}_{\mathrm{op}}\right.$ ) calculated from the data of the replacement series 1 (RS 1) for shoot, grain and grain- $\mathrm{N}$ yields of sole and intercropped pea and oat for 2002 and 2003 with the calculated optimal absolute densities of pea and oat $\left(d_{p o}{ }^{*}: d_{o p}{ }^{*}\right)$, maximum total intercrop yields $\left(\mathrm{Y}^{*}\right), \mathrm{RYT}$ at maximum total intercrop yield $\left(\mathrm{RYT}_{\max }\right)$ as well as the sole crop yields of pea $\left(Y_{\mathrm{pp}}\right)$ and oat $\left(\mathrm{Y}_{\mathrm{oo}}\right)$.

Table 3.3 Regression coefficients ( $r$ ) and crowding coefficients $\left(k_{p o}, k_{o p}\right)$ calculated from the data of the replacement series 2 (RS 2) for shoot, grain and grain-N yields of sole and intercropped pea and oat for 2002 and 2003 with the calculated optimal absolute densities of pea and oat $\left(\mathrm{d}_{\mathrm{po}}{ }^{*}: \mathrm{d}_{\mathrm{op}}{ }^{*}\right)$, maximum total intercrop yields $\left(\mathrm{Y}^{*}\right), \mathrm{RYT}$ at maximum total intercrop yield $\left(\mathrm{RY} \mathrm{T}_{\max }\right)$ as well as the sole crop yields of pea $\left(Y_{\mathrm{pp}}\right)$ and oat $\left(\mathrm{Y}_{\mathrm{oo}}\right)$.

Table 3.4 Regression coefficients $(r)$, competition coefficients $\left(b_{0}, b_{1} / b_{0}\right.$, $\mathrm{b}_{2} / \mathrm{b}_{0}, \mathrm{c}_{0}, \mathrm{c}_{1} / \mathrm{c}_{2}$ and $\mathrm{c}_{2} / \mathrm{c}_{0}$ given in $\left.\mathrm{x} 10^{3}\right)$ as well as competitive values $\left(R C=b_{1} / b_{2}, c_{1} / c_{2} ; N D I=\left(b_{1} / b_{2}\right) /\left(c_{2} / c_{1}\right)\right)$ calculated from the hyperbolic yield-density equation fitted to shoot, grain and grain- $\mathrm{N}$ of intercropped pea and oat for 2002 and 2003 with the calculated optimal densities of pea and oat $\left(\mathrm{d}_{\mathrm{po}}{ }^{*}: \mathrm{d}_{\mathrm{op}}{ }^{*}\right)$ and maximum total intercrop yields $\left(\mathrm{Y}^{*}\right)$. 


\section{Abbildungsverzeichnis}

Figure 2.1 Soil $\mathrm{N}$ and atmospheric $\mathrm{N}_{2}$ accumulation $\left(\mathrm{kg} \mathrm{N}^{-1}\right)$ in shoot of pea $(\mathrm{P})$ and oat $(\mathrm{O})$ sole $(\mathrm{s})$ and intercropped (i) in different densities and amount of mineral nitrogen in the soil $\mathrm{kg} \mathrm{N}_{\min }-\mathrm{N}$ $\mathrm{ha}^{-1}$ ) at final harvest and three $\mathrm{N}_{\min }-\mathrm{N}$ sampling dates in conventional (CT) and minimum (MT) tillage systems in 2002 (a)nd 2003 (b). Mixtures consist of: (1) 38 oat seeds $\mathrm{m}^{-2}$ intercropped with the mean of all pea densities, (2) 300 oat seeds $\mathrm{m}^{-2}$ intercropped with the mean of all pea densities, (3) 80 pea seeds $\mathrm{m}^{-2}$ intercropped with the mean of all oat densities and (4) 40 pea seeds $\mathrm{m}^{-2}$ intercropped with the mean of all oat densities; for the sole crops the means of all pea densities from 40 to 80 seeds $\mathrm{m}^{-2}$ and of all oat densities from 38 to 300 seeds were taken.

Figure 3.1 Nitrogen accumulated in grain $\left[\mathrm{kg} \mathrm{N} \mathrm{ha}^{-1}\right]$ of intercropped pea $(\bullet)$, oat (०) and the sum of intercropped pea and oat ( $\bullet$ ) calculated for replacement series 1 (RS 1; a, c) and 2 (RS 2; b, d) in 2002 (a, b) and 2003 (c, d).

Figure 3.2 Nitrogen accumulated in grain $\left[\mathrm{kg} \mathrm{N}^{-1}\right]$ of intercropped pea $(a, d)$, oat $(b, e)$ and the sum of intercropped pea and oat (c, f) in 2002 (a, b, c) and 2003 (d, e, f) calculated with the hyperbolic yield-density equation.

Figure 4.1 Entstehung der Erbsen-Hafer-Gemenge nach den verschiedenen Anbaumustern ausgehend von den Reinsaaten 


\section{Abkürzungen}

CT "Conventional Tillage“, konventionelle Bodenbearbeitung mit dem Wendepflug

DM „Dry Matter“, Trockenmasse

LSD "Least Significant Difference“, kleinster signifikanter Unterschied

MT „Minimum Tillage“, reduzierte Bodenbearbeitung mit Grubber und Kreiselegge

NDI „Niche Differentiation Index“, Nischendifferenzierungsindex; Berechnung vgl. Kapitel 3.3.5 (S. 39)

Ndfa "Nitrogen derived from atmosphere“, Anteil Stickstoff aus der Luft; Berechnung vgl. Kapitel 2.3.4 (S. 15)

NHI „Nitrogen Harvest Index“, Stickstoff-Ernteindex = Stickstoff im Erntegut im Verhältnis zu Stickstoff in der Gesamtpflanze

$\mathrm{N}_{\min } \quad$ „mineral soil nitrogen“, mineralischer Bodenstickstoff $\left(\mathrm{NO}_{3}-\mathrm{N}+\right.$ $\mathrm{NH}_{4}-\mathrm{N}$ )

RS 1 „Replacement Series 1“, Verdrängungsserie 1, basierend auf den Reinsaaten aus 80 Erbsensamen $\mathrm{m}^{-2}$ und 300 Haferkörnern $\mathrm{m}^{-2}$

RS 2 „Replacement Series 2“, Verdrängungsserie 2, basierend auf den Reinsaaten aus 120 Erbsensamen $\mathrm{m}^{-2}$ und 450 Haferkörnern $\mathrm{m}^{-2}$

RYT „Relative Yield Total“, Relativer Gesamtertrag des Gemenges; Berechnung vgl. Kapitel 3.3.4 (S. 38) 


\section{1 \\ Einleitung}

\subsection{Problemstellung}

In den entwickelten Ländern der Welt werden Feldfrüchte heute überwiegend als Reinsaaten angebaut. Diese Fruchtfolgegestaltung hin zu wenig komplexen Landnutzungssystemen mit geringen Artenzahlen begann Anfang des 20. Jahrhunderts mit der zunehmenden Verbesserung von Sorten sowie der Entwicklung eines hochspezifischen produktionstechnischen Instrumentariums wie mineralischen Düngern und chemischen Pflanzenschutzmitteln. Dies führte zum Wandel von rotierenden Landnutzungssystemen hin zu dem wiederholten Anbau hochertragreicher Feldfrüchte (Crews und Peoples, 2004). Die so entstandenen uniformen Pflanzenbestände sind unabhängiger von ökologischen Einflüssen, da sie stark durch Maßnahmen von Außen gelenkt werden, so dass hier Aspekte wie Bodenfruchtbarkeit, Pflanzenkrankheiten und Verunkrautung zunehmend an Bedeutung verlieren (Gliessman, 2007). Diese intensive Landnutzung führt zu Veränderungen der Landschaft, Verlust der Biodiversität sowie Beeinträchtigungen von Boden, Grund- und Oberflächenwasser. So ist die Landwirtschaft z.B. der Hauptverursacher für den Eintrag von Nitrat in das Grundwasser (Feldwisch und Frede, 1999). Bei Landwirten, Forschern, Politikern und Verbrauchern öffnet sich jedoch zunehmend das Bewusst- 
sein für die Verknüpfung von Landnutzungssystemen, Umweltschutz und Nachhaltigkeit. Dabei wird erkannt, dass Landwirtschaft neben der Erzeugung von Nahrungsmitteln auch noch anderen gesellschaftlichen Zielen dient. Der Erhöhung der Biodiversität wird dabei eine wichtige Rolle zugeschrieben (Altieri, 1999).

Der einfachste Schritt in Richtung erhöhter Biodiversität in der Landwirtschaft ist der Anbau von Gemengen. Der Gemengeanbau, d.h. der Anbau von mehreren Früchten auf einem Feld, ist eine altbekannte Technik, die gegenüber uniformen Reinsaaten viele Vorteile aufweisen kann, wie z.B. effizientere Ressourcennutzung (Keating und Carberry, 1993; HauggaardNielsen et al., 2001a), verbesserte Schädlingskontrolle (Mitchell et al., 2002), verringerte Krankheitsanfälligkeit (Hauggaard-Nielsen et al., 2008), geringeren Unkrautdruck (Kimpel-Freund, 1999) und erhöhte Produktqualität (Anil et al., 1998; Hof-Kautz, 2008). Insbesondere für den ökologischen Landbau, bei dem die Landwirte durch den Verzicht auf mineralische Dünger und chemische Pflanzenschutzmittel gezwungen sind die Mechanismen der Natur stärker zu nutzen, ist der Gemengeanbau eine interessante Anbautechnik. Unter den intensiven, mechanisierten Produktionsbedingungen sind jedoch auch hier nur Gemenge mit gleichzeitiger Ernte der beteiligten Komponenten relevant. Von besonderem Interesse sind dabei Gemenge aus Leguminosen und Getreide. Da das Getreide durch seine schnelle Jugendentwicklung in der Lage ist, den pflanzenverfügbaren Stickstoff des Bodens schnell aufzunehmen, ist die Leguminose im Gemenge stärker als in Reinsaat gezwungen, atmosphärischen Stickstoff zu fixieren. Die so erreichte komplementäre Nutzung von Ressourcen kann dabei häufig zu Ertragsvorteilen gegenüber den Reinsaaten führen.

Nicht jedes Leguminosen-Getreide-Gemenge führt jedoch zwangsläufig zu Ertragsvorteilen. Für die in der vorliegenden Arbeit untersuchten Gemengepartner Erbse und Hafer wurde bereits häufig über Ertragsvorteile berichtet (z.B. Brouwer, 1976; Carr et al., 1996; Rauber et al., 2001; Lauk und Lauk, 2008). Lauk und Lauk (2008) überprüften Erbsen im Gemenge mit verschiedenen Sommergetreidearten hinsichtlich ihrer Ertragsvorteile gegenüber den Reinsaaten und fanden höchste Korn- und Proteinerträge für das Erbsen-Hafer-Gemenge, da der Hafer anspruchslos und konkurrenz- 
kräftig ist. Sind passende Gemengepartner gefunden, so spielt auch die Wahl der Aussaatstärken eine entscheidende Rolle für das Erreichen von Ertragsvorteilen. Rauber et al. (2001) stellten für Erbsen-Hafer-Gemenge fest, dass keine Mehrerträge wie erwartet, sondern sogar Mindererträge auftreten können, wenn die Erbse zu stark vom Hafer unterdrückt wird. Die Kenntnis des Konkurrenzgeschehens im Gemenge ist also für die Auswahl von Aussaatstärken, die zu einem ausgewogenen Verhältnis zwischen den beiden Gemengepartnern Erbsen und Hafer und damit zu maximalen Ertragsvorteilen führen, essentiell.

Der Anbau von Erbsen in Reinsaat kann zu sehr hohen residualen $\mathrm{N}_{\min }{ }^{-}$ Gehalten nach der Ernte und damit erhöhten N-Auswaschungsverlusten führen, während diese Gefahr im Gemenge mit Getreide durch die stärkere Boden-N-Aufnahme des Getreidepartners verringert wird (HauggaardNielsen et al., 2001b). Dabei stellt sich die Frage, welche Aussaatstärken im Erbsen-Hafer-Gemenge zu einer Reduktion der N-Auswaschungsgefahr führen und ob diese Aussaatstärken mit denen zur Erreichung maximaler Ertragsvorteile übereinstimmen.

Die komplementäre Nutzung von Stickstoff in Leguminosen-Getreide-Gemengen, die durch die Fähigkeit der Leguminose zur $\mathrm{N}_{2}$-Fixierung entsteht, wird nicht allein durch das Konkurrenzgeschehen im Gemenge beeinflusst. So führt z.B. die Umstellung von wendender auf reduzierte Bodenbearbeitung zu einer Erhöhung der $\mathrm{N}_{2}$-Fixierleistung von Leguminosen (Peoples et al., 1995; Van Kessel und Hartley, 2000). Reiter (2002) ermittelte für Erbsen in Reinsaat eine Erhöhung der Anteile an Stickstoff aus der Luft um 20 Prozentpunkte bei reduzierter gegenüber wendender Bodenbearbeitung. Somit liegt die Vermutung nahe, dass die Bodenbearbeitung auch die $\mathrm{N}_{2-}$ Fixierung der Erbse im Gemenge und damit die Ertragsvorteile in einem Erbsen-Hafer-Gemenge beeinflussen kann.

Das bessere Verständnis des Konkurrenzgeschehens in Gemengen und die Ermittlung von optimalen Aussaatstärken zur Erzielung maximaler Gesamterträge beschäftigt die Wissenschaft seit Jahrzehnten. Dabei wurden zahlreiche Versuche durchgeführt, die verschiedenen Anbaumustern folgten. Das am häufigsten verwendete Anbaumuster ist das substitutive, das 1960 von De Wit vorgestellt wurde. Hier wird die Gesamtdichte des 
Gemenges konstant gehalten, während die Dichten beider Gemengepartner variiert werden. Trotz häufiger Kritik an diesem Anbaumuster bezüglich der Dichteabhängigkeit und Eindimensionalität (De Benedictis, 1977; Firbank und Watkinson, 1985; Connolly, 1986; Law und Watkinson, 1987; Taylor und Aarssen, 1989; Connolly et al., 1990; Cousens und O'Neill, 1993; Inouye, 2001), sowie der Vermengung von intra- und interspezifischer Konkurrenz (Jolliffe et al., 1984; Snaydon, 1991; Snaydon, 1994) wird es bis heute angewendet, da seine Anwendung mathematisch einfach ist (Cousens, 1985). Ähnliche Kritik bezüglich der Eindimensionalität wurde auch für das additive Anbaumuster formuliert (Watkinson, 1985; Rejmanek et al., 1989; Sackville Hamilton, 1994; Inouye, 2001), bei dem die Aussaatstärke eines Gemengepartners konstant gehalten wird, während die des anderen variiert wird. Als Reaktion auf die Kritiken am substitutiven und additiven Anbaumuster wurde das „Response Surface“-Anbaumuster entwickelt, bei dem die Aussaatstärken beider Gemengepartner unabhängig voneinander variiert werden. Die mathematische Beschreibung der bei diesem Anbaumuster entstehenden dreidimensionalen Kurve gestaltet sich jedoch schwierig. In der Literatur finden sich zahlreiche Gleichungen, die diese Kurve beschreiben sollen, aber mit zunehmender Anzahl von Koeffizienten und mathematischen Berechnungen nehmen die Zweifel an deren Gültigkeit zu (Weigelt und Jolliffe, 2003). Cousens (1985) führte anhand von Felddaten von Weizen-Gerste-Gemengen einen Vergleich 13 verschiedener Gleichungen durch. Dabei stellte sich eine einfache hyperbolische Gleichung mit drei, zur quantitativen Ermittlung intraund interspezifischer Konkurrenz nutzbaren Koeffizienten als sehr geeignet heraus, die Wright 1981 erstmalig verwendete (Cousens, 1985). Aufgrund des hohen Versuchsaufwands bleibt die Verwendung des „Response Surface“-Anbaumusters bei Gemengeversuchen jedoch bis heute hinter der des substitutiven Anbaumusters zurück. Die Auswahl eines Anbaumusters bei der Planung von Feldversuchen sollte sich jedoch nicht nach der Einfachheit richten, sondern danach, welches Ziel mit dem Versuch verfolgt wird (Cousens, 1990). Jedes Anbaumuster hat seine Stärken und Schwächen, die zu überprüfen und in zukünftige Versuchsplanungen einzubeziehen von großer Wichtigkeit für die Gemengeforschung ist. Die vorliegende Arbeit untersucht und vergleicht dabei das substitutive und das „Response 
Surface“-Anbaumuster unter Verwendung der hyperbolischen 3-ParameterGleichung von Wright (1981).

\subsection{Ziele}

In der vorliegenden Arbeit wurden Spross-, Korn- und N-Erträge sowie symbiotische $\mathrm{N}_{2}$-Fixierleistung und residuale $\mathrm{N}_{\text {min }}$-Gehalte von verschiedenen Erbsen-Hafer-Gemengen bei gepflügter und ungepflügter Bodenbearbeitung geprüft und mit den Reinsaaten verglichen. Erbsen und Hafer wurden jeweils in vier verschiedenen Aussaatstärken angebaut. So entstanden 16 unterschiedliche Gemengezusammensetzungen, in denen zwei verschiedene Verdrängungsserien des substitutiven Anbaumusters enthalten waren, während alle untersuchten Gemenge dem „Response Surface“Anbaumuster zugeordnet werden konnten.

Dabei waren die wichtigsten Ziele

- $\quad$ Aussaatstärken zu ermitteln, die zu maximalen Ertragsvorteilen beim Korn- und Korn-N-Ertrag gegenüber den Reinsaaten bei geringen residualen $\mathrm{N}_{\min }$-Gehalten führen (Kapitel 2),

- $\quad$ zu untersuchen, ob sich unterschiedliche Bodenbearbeitungen auf das Konkurrenzgeschehen und die Ertragsvorteile eines ErbsenHafer-Gemenges auswirken (Kapitel 2),

- das substitutive und das „Response Surface“-Anbaumuster hinsichtlich ihrer Ergebnisse und Rückschlüsse auf Konkurrenzgeschehen, Ressourcenkomplementarität und optimale Aussaatstärken zu vergleichen sowie die Anwendbarkeit beider Anbaumuster für Feldversuche zu überprüfen (Kapitel 3).

In Kapitel 4 werden die Ergebnisse aus den vorherigen Kapiteln abschließend diskutiert. Durchführung und Ergebnisse der Feldversuche nach den verschiedenen Anbaumustern werden kritisch betrachtet. Anschließend erfolgt ein Ausblick auf die weitere Gemengeforschung. 


\subsection{Literatur}

Altieri, M.A., 1999. The ecological role of biodiversity in agroecosystems. Agric. Ecosyst. Environ. 74, 19-31.

Anil, L., Park, R.H.P., Miller, F.A., 1998. Temperate intercropping of cereals for forage: a review of the potential for growth and utilization with particular reference to the UK. Grass Forage Sci. 53, 301-317.

Brouwer, W., 1976. Handbuch des Speziellen Pflanzenbaus. II. Kartoffeln, Beta-Rüben, Raps und Rübsen, Erbsen, Ackerbohnen. Paul Parey Verlag, Berlin und Hamburg, 505.

Carr, M.P., Eriksmoen, E.D., Martin, G.B., Olson, N.R., 1996. Grain yield of oat-pea intercrop. In: Janick, J. (Hrsg.). Progress in new crops. ASHS Press, Alexandria, VA.

Connolly, J., 1986. On difficulties with replacement-series methodology in mixture experiments. J. Appl. Ecol. 23, 125-137.

Connolly, J., Wayne, P., Murray , R., 1990. Time course of plant-plant interactions in experimental mixtures of annuals: density, frequency, and nutrient effects. Oecologia 82, 513-526.

Cousens, R., 1985. An empirical model relating crop yield to weed and crop density and a statistical comparison with other models. J. agric. Sci. 105, 513-521.

Cousens, R., 1990. Aspects of the Design and Interpretation of Competition (Interference) Experiments. Weed Technol..5, 664-673.

Cousens, R., O’Neill, M., 1993. Density dependence of replacement series experiments. Oikos 66, 347-352.

Crews, T.E., Peoples, M.B., 2004. Legume versus fertilizer sources of nitrogen: ecological tradeoffs and human needs. Agric. Ecosyst. Environ. 102, 279-297.

De Benedictis, P.A., 1977. The meaning and measurement of frequency-dependent competition. Ecol. 58, 158-166.

De Wit, C.T., 1960. On competition. Versl. Landbouwk. Onderz. 66.8. Pudoc, Wageningen.

Feldwisch, N., Frede, H.-G., 1999. Stoffeinträge ins Gewässer aus der Landwirtschaft. In: Frede, H.-G., Dabbert, S. (Hrsg.). Handbuch zum Gewässerschutz in der Landwirtschaft. Verlag ecomed, Landsberg, 2. Auflage, 4-21.

Firbank, L.G., Watkinson, A.R., 1985. On the analysis of competition within two-species mixtures of plants. J. Appl. Ecol. 22, 503-517.

Gliessman, S.R., 2007. Agroecology. The ecology of sustainable food systems. CRC Press, Boca Raton, 2. Auflage, S. 3 ff.

Hauggaard-Nielsen, H., Ambus, P., Jensen, E.S., 2001a. Interspecific competition, N use and interference with weeds in pea-barley intercropping. Field Crops Res. 70, 101-109.

Hauggaard-Nielsen, H., Ambus, P., Jensen, E.S., 2001b. Temporal and spatial distribution of roots and competition for nitrogen in pea-barley intercrops - a field study employing ${ }^{32} \mathrm{P}$ technique. Plant Soil 236, 63-74.

Hauggaard-Nielsen, H., Jørnsgaard, B., Kinane, J., Jensen, E.S., 2008. Grain legume-cereal intercropping: The practical application of diversity competition and facilitation in arable and organic cropping systems. Renew. Agric. Food Syst. 23, 3-12. 
Hof-Kautz, C., 2008. Ursachen höherer Backqualität von Winterweizen (Triticum aestivum

L.) im Gemenge mit Winterackerbohne (Vicia faba L.) oder Wintererbse (Pisum sativum

L.). Dissertation, Georg-August-Universität Göttingen.

Inouye, B.D., 2001. Response surface experimental designs for investigating interspecific competition. Ecol. 82, 2696-2706.

Jolliffe, P.A., Minjas, A.N., Runeckles, V.C., 1984. A reinterpretation of yield relationships in replacement series experiments. J. Appl. Ecol. 21, 227-243.

Keating, B.A., Carberry, P.S., 1993. Resource capture and use in intercropping - solarradiation. Field Crops Res. 34, 273-301.

Kimpel-Freund, H., 1999. Konkurrenz und Unkrautunterdrückung der Erbse (Pisum sativum L.) in Reinsaat und Gemenge mit Hafer (Avena sativa L.). Dissertation, Georg-AugustUniversität Göttingen.

Lauk, R., Lauk, E., 2008. Pea-oat intercrops are superior to pea-wheat and pea-barley intercrops. Acta Agriculturae Scandinavica Section B - Soil and Plant Science 58, 139144.

Law, R., Watkinson, A.R., 1987. Response-Surface Analyses of Two-Species Competition: An Experiment on Phleum arenarium and Vulpia fasciculata. J. Ecol. 75, 871-886.

Mitchell, C.E., Tilman, C., Groth, J.V. , 2002. Effects of grassland plant species diversity, abundance and composition on foliar fungal disease. Ecol. 83, 1713-1726.

Peoples, M.B., Ladha, J.K., Herridge, D.F., 1995. Enhancing legume $\mathrm{N}_{2}$ fixation through plant and soil management. Plant Soil 174, 83-101.

Rauber, R., Schmidtke, K., Kimpel-Freund, H., 2001. The performance of pea (Pisum sativum L.) and its role in determining yield advantages in mixed stands of pea an oat (Avena sativa L.). J. Agron. Crop Sci. 187, 137-144.

Reiter, K., 2002. Einfluss langjährig differenzierter Bodenbearbeitung auf die $\mathrm{N}_{2^{-}}$ Fixierungsleistung von Erbse und Rotklee, ermittelt mit Hilfe einer großflächigen ${ }^{15} \mathrm{~N}$ Spurenanreicherung. Dissertation, Georg-August-Universität Göttingen.

Rejmanek, M., Robinson, G.R., Rejmankova, E., 1989. Weed - crop competition: experimental designs and models for data analysis. Weed Sci. 37, 276-284.

Sackville Hamilton, N.R., 1994. Replacement and additive designs for plant competition studies. J. Appl. Ecol. 31, 599-603.

Snaydon, R.W., 1991. Replacement or additive designs for competition studies? J. Appl. Ecol. 28, 930-946.

Snaydon, R.W., 1994. Replacement and additive designs revisited: Comments on the review paper by N.R. Sackville Hamilton. J. Appl. Ecol. 31, 784-786.

Taylor, D.R., Aarssen, L.W., 1989. On the density dependence of replacement-series competition experiments. J. Ecol. 77, 975-988.

Van Kessel, C., Hartley, C., 2000. Agricultural management of grain legumes: has it led to an increase in nitrogen fixation? Field Crops Res. 65, 165-181.

Watkinson, A.R., 1985. Plant responses to crowding. In: J. White, J. (Hrsg.): Studies on Plant Demography. Academic Press, London, 275-289.

Weigelt, A., Jolliffe, P., 2003. Indices of plant competition. J. Ecol. 91, 707-720.

Wright, A.J., 1981. The analysis of yield-density relationships in binary mixtures using inverse polynomials. J. Agric. Sci. Camb. 96, 561-567. 



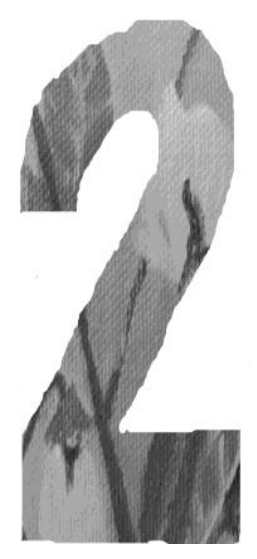

\title{
Effects of crop density and tillage system on grain yield and $\mathrm{N}$ uptake from soil and atmosphere of sole and intercropped pea and oat
}

\author{
Angelika Neumann, Knut Schmidtke, Rolf Rauber (2007) \\ Field Crops Research 100, 285-293 \\ gedruckt mit Genehmigung von Elsevier
}

\subsection{Abstract}

Pea (Pisum sativum L.) and oat (Avena sativa L.) were grown as sole and intercrops in various densities under two different tillage systems on a loess soil near Goettingen/Germany in a 2-year field experiment (2002/2003). In the conventional tillage system a moldboard plough (CT) was used and in the minimum tillage system a rotary harrow (MT) was employed. The effect of crop density and tillage system on the grain dry matter and grain $\mathrm{N}$ yields, $\mathrm{N}_{2}$ fixation and soil $\mathrm{N}$ uptake were determined to address the following questions: (i) which mixture compositions exhibit the highest grain yields compared to the sole crops, (ii) which mixture compositions also fix a high level of $\mathrm{N}_{2}$ and leave low levels of residual inorganic soil $\mathrm{N}$ after harvest and (iii) whether the intercrop advantage is influenced by the tillage system. For (i) the result in 2002 showed that the highest grain yields of both sole cropped pea and oat and intercropped pea and oat were achieved at the highest densities. In 2003, when inorganic soil 
$\mathrm{N}$ content was higher and weather conditions were warmer and drier, grain yields were significantly higher than in 2002, but sole as well as intercropped pea and oat gave their highest grain yields at lower densities. For both years and tillage systems, the highest intercrop advantages were achieved in mixtures with densities above the optimal sole crop densities. The result for (ii) was that a distinctly higher proportion of nitrogen was derived from atmosphere (Ndfa) by intercropped pea than that by sole cropped pea. However, the uptake of soil $\mathrm{N}$ by intercropped pea and oat was not reduced in comparison with that of sole cropped oat as the decrease in the uptake of $\mathrm{N}$ from the soil by oat at lower oat densities in the mixture was compensated for by the soil $\mathrm{N}$ uptake of pea. Additionally, the $\mathrm{N}_{\min }-\mathrm{N}$ content of the soil following the mixtures and sole cropped oat did not differ, especially in the deeper soil layers because oat in mixture was forced to take up more soil $\mathrm{N}$ from deeper layers. Therefore, the risk of soil $\mathrm{N}$ losses through leaching after mixtures was lower compared to sole cropped pea. The tillage system (iii) had no significant influence on grain yield and soil $\mathrm{N}$ uptake, but $\mathrm{N}_{2}$ fixation and competitive ability of intercropped pea were higher under CT than with MT. An additional result was that intercropping led to a significantly increased grain $\mathrm{N}$ content of both pea and oat compared to the sole crops. The increase in grain $\mathrm{N}$ content from sole to intercrop was from 3.30 to $3.42 \%$ for pea and from 1.73 to $1.96 \%$ for oat as a mean for both years and tillage systems. The present study confirms that growing pea and oat as intercrops highlights potential economic and environmental benefits which still need to be understood in more detail to exploit intercropping to a greater extent. 


\subsection{Introduction}

The field pea (Pisum sativum L.) is the most common grain legume in middle Europe (Stratmann et al., 2004) and an important domestic protein fodder for farm animals. Because of the ability of pea to fix atmospheric nitrogen, its cultivation can reduce the use of mineral nitrogen fertilizer and therefore contribute to the saving of fossil energy resources and to a reduction of $\mathrm{CO}_{2}$ emissions. The intercropping of legumes with nonlegumes often produces an advantage in terms of increased grain yield (Carr et al., 1995; Jensen, 1996a), higher $\mathrm{N}$ content in the fodder (Cowell et al., 1989; Droushiotis, 1989) and more efficient use of growth limiting resources (Wilson, 1988). The resource complementarity of $\mathrm{N}$ especially, which arises from the ability to fix atmospheric $\mathrm{N}_{2}$, seems to be an important component of the intercropping advantage (Tofinga et al., 1993). Reduced tillage may enhance the symbiotic $\mathrm{N}_{2}$ fixation by pea compared with conventional tillage (Reiter et al., 2002). This increase in symbiotic $\mathrm{N} 2$ fixation results from a reduced soil $\mathrm{N}$ availability in reduced compared with conventionally tilled soils, as immobilization predominates the mineralization of soil $\mathrm{N}$ when ploughing first ceases (Doran, 1980). Therefore it seems likely that the intercrop advantage given by mixing a legume and a nonlegume is influenced by the tillage system.

Most of the studies with pea and a cereal species in mixture have been undertaken using the replacement series design where the total relative seed frequency of the mixture is equal to the relative seed frequency of the sole crops (Tofinga and Snaydon, 1992; Jensen 1996a, 1996b; Rauber et al. 2000, 2001; Hauggaard-Nielsen and Jensen, 2001). On the other hand, an increasing number of authors have found that advantages can be gained by growing mixtures of legumes and nonlegumes when grown in total densities higher than those of the sole crops in comparison to replacement series mixtures. This has been observed for mixtures with faba bean (Vicia faba L.) and wheat (Triticum aestivum L.; Bulson et al., 1997), pea and barley (Hordeum vulgare L.; Carr et al., 1998), faba bean and oat (Helenius and Jokinen, 1994) and soybean (Glycine $\max$ (L.) Merr.) and maize (Zea mays L.; Yunusa, 1989). The composition of the mixture may not only influence grain and nitrogen yield, but also the use of mineral $\mathrm{N}$ from the soil. While the growing of sole cropped grain legumes in a temperate climate when precipitation exceeds evapotranspiration 
often results in a higher risk of $\mathrm{N}$ losses through leaching, mixtures of legumes and nonlegumes are able to use mineral nitrogen more efficiently than monocropped grain legumes (Hauggaard-Nielsen et al., 2001). In order to reduce the risk of $\mathrm{N}$ losses through leaching, a low residual inorganic soil $\mathrm{N}$ is aimed for when growing grain legumes in a temperate climate. No information is available about the effect of the mixture composition on the use of mineral soil $\mathrm{N}$ and the amount of residual inorganic soil $\mathrm{N}$ after the harvest of different mixtures of pea and oat. Although the grain legume's percentage of nitrogen derived from the atmosphere increases due to intercropping with a cereal crop, the level of symbiotic $\mathrm{N}_{2}$ fixation will be lowered in mixed stands (Danso et al., 1987; Cowell et al., 1989; Schmidtke et al., 2004). Therefore, in the present study, 16 mixtures of pea and oat in different densities under a conventional and a minimum tillage system were compared. The aim of the study was to test the effect of different tillage systems on $\mathrm{N}_{2}$ fixation of pea as a sole and as an intercrop, and on the grain yield and intercrop advantage of the mixtures. The compositions of mixtures with high grain yields, high $\mathrm{N}_{2}$ fixation and low residual inorganic soil $\mathrm{N}$ after harvest should be identified.

\subsection{Material and methods}

\subsubsection{Soil and growing conditions}

The field experiments were conducted in 2002 and 2003 on a brown warp soil (Fluventic Eutrochrept) near Göttingen (5132' N, 956’ E), Germany. The topsoil $(0-0.3 \mathrm{~m})$ of the experimental field was a silty loam with a clay proportion of 0.178 , silt 0.683 , and sand 0.139 (Jung, 2003) and a pH of 7.1. In the soil layer $0-0.2 \mathrm{~m}$ the proportion of total soil $\mathrm{DM}$ was $1.2 \% \mathrm{C}$ and $0.1 \% \mathrm{~N}$. The amount of plant available water stored in the $1.2 \mathrm{~m}$ soil profile was 201 $\mathrm{mm}$. The agricultural land had been cultivated with two different tillage systems:

(1) Conventional tillage system (CT) with a mouldboard plough at a tillage depth of $0.3 \mathrm{~m}$, followed by one pass with a rotary harrow to prepare the seedbed.

(2) Minimum tillage system (MT) with a rotary harrow at a tillage depth of $0.08-0.12 \mathrm{~m}$, followed by a seedbed preparation as in the CT. 
The agricultural land used for the experiment had been cultivated with minimum tillage system (MT) since 1998. Differentiated tillage systems in main plots had been established in 2000 .

For the vegetation period from April until the end of July, the temperature at Göttingen (long-term average $1961-1990$ ) was $13.4^{\circ} \mathrm{C}$ and the precipitation is $253 \mathrm{~mm}$. The precipitation in both experimental years differed considerable from the long-term average (2002: $338 \mathrm{~mm} ; 2003: 185 \mathrm{~mm}$ ).

Sugar beet and cereals had been grown in the years preceding on the site. The crop grown before both experiments was summer barley (H. vulgare L.) fertilized with $70 \mathrm{~kg} \mathrm{~N} \mathrm{ha}^{-1}$. The barley straw was finely chopped and left on the field. After the harvest of barley in 2001 and 2002 the stubble was cultivated with a rotary harrow. Plots under CT were ploughed in the late autumn. During the experiment no N, P or K-fertilizer was applied. During both vegetation periods the crops were protected chemically with insecticides and herbicides.

\subsubsection{Field design}

The field trial was arranged in a randomized split-plot design for each year (main plot: tillage systems, four replicates; subplot: crop stands, four replicates). The mixtures were grown in alternate rows. Row spacing of monocultures and mixtures was $0.122 \mathrm{~m}$, therefore the distance between the same species in mixture was $0.244 \mathrm{~m}$. A subplot consisted of 10 rows with a length of $7.8 \mathrm{~m}$. The subplot size was $9.5 \mathrm{~m}^{2}$. Pea (Pisum sativum L. cv. Classic) as a sole crop was grown at 40, 60, 70, 80 and 120 seeds $\mathrm{m}^{-2}$. Oat (Avena sativa L. cv. Alf) as a sole crop was grown at 38, 75, 150, 300 and 450 seeds $\mathrm{m}^{-2}$. The pea variety Classic is a semi-leafless variety with a high yield potential, and was therefore assumed to be highly competitive. The oat variety Alf, due to its early maturity, is well-suited for use in mixtures with pea. The mixtures consisted of all density combinations of pea from 40 to 80 seeds $\mathrm{m}^{-2}$ and oat from 38 to 300 seeds $\mathrm{m}^{-2}$, giving 16 combinations of densities in total. 


\subsubsection{Sampling procedure and analysis}

Plants were harvested at maturity of both plant species (30 July 2002 for sole cropped pea, 5 August 2002 for sole cropped oat and intercropped pea and oat, and 19 July 2003 for all sole and intercrops). The shoot was cut from an area of $1.464 \mathrm{~m}^{2}$ (six rows at a length of $2 \mathrm{~m}$ ) at each harvest. Shoots, separated into grain and straw, were dried to a constant weight at $60^{\circ} \mathrm{C}$. The effects of intraand interspecific competition were deduced from the decrease in grain and straw yield of pea or oat due to the increase of individuals of the same species or the intercropped species. The terms "intraspecific competition" and "interspecific competition" are used following Begon et al. (2006; p. 132, p. 227).

The dried grain and straw were milled to a fine powder with a particle size $<0.2$ $\mathrm{mm}$ (Retsch ZM 100). Analyses of total $\mathrm{N}$ content and the ${ }^{15} \mathrm{~N} /{ }^{14} \mathrm{~N}$ ratio in the biomass were carried out using an isotope ratio mass spectrometer (Finnigan MAT 251 or ThermoQuest Finnigan DELTAplus). Immediately after sowing, following the harvest and at the end of September the mineral nitrogen $\left(\mathrm{N}_{\min }-\mathrm{N}\right.$ $=\mathrm{NO}_{3}-\mathrm{N}+\mathrm{NH}_{4}-\mathrm{N}$; from 0 to $1.20 \mathrm{~m}$ depth, four equal horizontal sections) was extracted from the soil using $0.01 \mathrm{M}$ of $\mathrm{CaCl}_{2}$ (Hoffmann, 1991). Nitrate and ammonium were quantified using a Perstorp analytical auto analyser (Flow Solution III). The soil samples were taken with the aid of a soil core sampling set (four soil cores from each plot with a diameter of $17 \mathrm{~mm}$ ), immediately homogenized and then frozen for further evaluation.

The proportions of $\mathrm{N}$ derived from soil and atmosphere were estimated using the natural proportion of ${ }^{15} \mathrm{~N} /{ }^{14} \mathrm{~N}$ in the soil and atmospheric $\mathrm{N}_{2}\left(\delta^{15} \mathrm{~N}\right.$ method; Shearer and Kohl, 1986). In order to estimate the level of $\mathrm{N}_{2}$ fixation, pea was also grown on $\mathrm{N}$-free vermiculite in a greenhouse (four replicates). A nutrient solution containing basic nutrients excluding N (Kessler, 1987) and de-ionized water was given to the vermiculite as needed to guarantee an adequate nutrient and water supply. The germinating pea seeds were inoculated by adding a solution of Rhizobium leguminosarum (strain DSM 30132, German collection of microorganisms and cell cultures). After harvesting, the weighted $\delta^{15} \mathrm{~N}$ values $\left(\delta^{15} \mathrm{~N}_{\mathrm{w}}\right)$ of the pea shoot biomass grown on $\mathrm{N}$-free vermiculite were determined. This led to a $\delta^{15} \mathrm{~N}_{\mathrm{w}}$ value of 0.623 . As the $\delta^{15} \mathrm{~N}$ value of the intercropped pea of the field experiment was lower than the $\delta^{15} \mathrm{~N}$ value of the pea grown on $\mathrm{N}$-free medium, it was assumed that the pea plants grown on $\mathrm{N}$-free medium 
completely resorbed the $\mathrm{N}$ from the pea seed. Therefore the $\delta^{15} \mathrm{~N}_{\mathrm{w}}$ values were corrected to account for the $\delta^{15} \mathrm{~N}$ value of the pea seed. The corrected $\delta^{15} \mathrm{~N}$ value of the pea was $-1.219\left(\delta^{15} \mathrm{~N}_{0}\right)$.

\subsubsection{Calculations}

When calculating weighted $\delta^{15} \mathrm{~N}$ values the single plant parts were accounted for as described by Danso et al. (1993). The proportion of nitrogen derived from the atmosphere in pea shoot biomass (Ndfa) was determined using the equation of Shearer and Kohl (1986):

$\operatorname{Ndfa}(\%)=\frac{\delta^{15} \mathrm{~N}_{\text {oat }}-\delta^{15} \mathrm{~N}_{\text {pea }}}{\delta^{15} \mathrm{~N}_{\text {oat }}-\delta^{15} \mathrm{~N}_{0}} \times 100$,

where $\delta^{15}$ Noat is the weighted $\delta^{15} \mathrm{~N}$ in the shoot of the reference plant oat, $\delta^{15} \mathrm{Npea}$ the weighted $\delta^{15} \mathrm{~N}$ in the shoot of the pea and $\delta^{15} \mathrm{~N}_{0}$ the weighted $\delta^{15} \mathrm{~N}$ value of the symbiotically fixed $\mathrm{N}_{2}$ in the shoot of the pea grown on $\mathrm{N}$-free vermiculite. High spatially variations of $\delta^{15} \mathrm{~N}$ within the replicates were apparent in the experimental field. As $\delta^{15} \mathrm{~N}$ in the shoot of sole and intercropped oat did not differ significantly, no transfer of symbiotically fixed $\mathrm{N}_{2}$ from intercropped pea to intercropped oat could be detected. Therefore intercropped oat was taken as the reference plant for intercropped pea and the nearest located sole or intercropped oat as reference plant for sole cropped pea. The nitrogen harvest indices of sole and intercropped pea and oat and those of the mixtures were calculated as described by Schmidtke et al. (2004).

\subsubsection{Statistical analysis}

The General Linear Models (GLM) of the Statistical Analysis System (SAS) was used to analyse the variance (Version 8.1, SAS Institute, Cary, NC). Normal distribution within the system was tested using the UNIVARIATE NORMAL procedure. All statistical analyses were done within individual procedures using arithmetical means of original data. 


\subsection{Results}

\subsubsection{Sole crop grain yield}

In 2002 the highest grain yields for both sole cropped pea and oat were found at the highest densities of 120 pea and 450 oat seeds $\mathrm{m}^{-2}$ for both tillage systems (Table 2.1; italicised figures). In 2003 grain yields of both sole cropped pea and oat were higher than in the previous year, but the highest grain yields were achieved at lower densities and higher densities gave decreasing grain yields for both tillage systems. The highest grain yields in 2003 for sole cropped pea were found at optimal densities of 70 and 80 seeds $\mathrm{m}^{-2}$ and for sole cropped oat at optimal densities of 75 seeds $\mathrm{m}^{-2}$ (Table 2.1; italicised figures). Grain yields of sole cropped pea and oat did not show significant differences between tillage systems.

Table 2.1

Grain yields ( $\left.\mathrm{Mg} \mathrm{ha}^{-1}\right)$ of sole cropped pea and oat with various seed densities (means for both tillage systems)

\begin{tabular}{|c|c|c|c|c|c|}
\hline \multicolumn{3}{|l|}{ Pea } & \multicolumn{3}{|l|}{ Oat } \\
\hline \multirow[t]{2}{*}{$\begin{array}{l}\text { Seed density } \\
\left(\text { seeds } \mathrm{m}^{-2}\right)\end{array}$} & \multicolumn{2}{|c|}{$\begin{array}{l}\text { Grain yield } \\
\left(\mathrm{Mg} \mathrm{ha}^{-1}\right)\end{array}$} & \multirow[t]{2}{*}{$\begin{array}{l}\text { seed density } \\
\left(\text { seeds } \mathrm{m}^{-2} \text { ) }\right.\end{array}$} & \multicolumn{2}{|c|}{$\begin{array}{l}\text { Grain yield } \\
\left(\mathrm{Mg} \mathrm{ha}^{-1}\right)\end{array}$} \\
\hline & 2002 & 2003 & & 2002 & 2003 \\
\hline 40 & 2.3 & 3.9 & 38 & 3.2 & 5.2 \\
\hline 60 & 2.9 & 3.9 & 75 & 3.2 & 5.5 \\
\hline 70 & 3.3 & 4.5 & 150 & 3.5 & 5.4 \\
\hline 80 & 3.8 & 4.5 & 300 & 3.9 & 5.4 \\
\hline 120 & 4.1 & 4.2 & 450 & 4.0 & 5.2 \\
\hline LSD (0.05) & 0.9 & 0.7 & & 0.9 & 0.7 \\
\hline Tillage system $^{a}$ & n.s. & & & n.s. & \\
\hline Year $^{\mathrm{a}}$ & n.s. & & & $\star * \star$ & \\
\hline Tillage system $x$ year ${ }^{a}$ & n.s. & & & n.s. & \\
\hline
\end{tabular}

Component of variation (Tukey's Test): ${ }^{* * *}$ significant at $P<0.001$ level; n.s., not significant.

${ }^{a}$ Analyses of variance were done using arithmetical means of all densities of sole cropped pea and oat. 


\subsubsection{Intercropping advantage}

Grain yields of the intercrops in the mean of the tillage systems are shown in Table 2.2. The intercropped pea and oat yield was always less than that of the respective sole cropped pea and oat. The decrease in grain yield was obviously more severe for pea than for oat as oat was the stronger competitor, especially in 2003. Therefore the proportion of grain yield of oat in the total intercrop grain yield was higher and that of pea lower than would be expected from the seed ratios. Nevertheless, the decrease in grain yield of one species was compensated for by the grain yield of the other species, even when only low densities were added, so that in both years and tillage systems combinations of intercropped pea and oat existed which gave grain yields greater than the grain yields reached by the respective optimal sole crop densities.

Table 2.2

Grain yields ( $\mathrm{Mg} \mathrm{ha}^{-1}$ ) of intercropped (i) pea, intercropped (i) oat and the sum of intercropped (i) pea and oat with the respective seed densities (means for both tillage systems)

\begin{tabular}{|c|c|c|c|c|c|c|c|}
\hline \multicolumn{2}{|c|}{$\begin{array}{l}\text { Seed density } \\
\text { (seeds } \mathrm{m}^{-2} \text { ) }\end{array}$} & \multicolumn{3}{|c|}{$\begin{array}{l}\text { 2002: Grain yield } \\
\left(\mathrm{Mg} \mathrm{ha}^{-1}\right)\end{array}$} & \multicolumn{3}{|c|}{$\begin{array}{l}\text { 2003: Grain yield } \\
\left(\mathrm{Mg} \mathrm{ha}^{-1}\right)\end{array}$} \\
\hline Pea (i) & Oat (i) & Pea (i) & Oat (i) & $\begin{array}{l}\text { Pea }+ \\
\text { Oat (i) }\end{array}$ & Pea (i) & Oat (i) & $\begin{array}{l}\text { Pea }+ \\
\text { Oat (i) }\end{array}$ \\
\hline $\begin{array}{l}40 \\
60 \\
70 \\
80\end{array}$ & 38 & $\begin{array}{l}1.3 \\
2.0 \\
2.2 \\
2.1\end{array}$ & $\begin{array}{l}2.3 \\
1.9 \\
1.7 \\
1.6\end{array}$ & $\begin{array}{l}3.6 \\
3.9 \\
3.9 \\
3.7\end{array}$ & $\begin{array}{l}2.0 \\
2.7 \\
2.8 \\
3.2\end{array}$ & $\begin{array}{l}3.3 \\
2.5 \\
2.8 \\
1.8\end{array}$ & $\begin{array}{l}5.3 \\
5.2 \\
5.6 \\
5.0\end{array}$ \\
\hline $\begin{array}{l}40 \\
60 \\
70 \\
80\end{array}$ & 75 & $\begin{array}{l}1.2 \\
1.5 \\
1.6 \\
2.0\end{array}$ & $\begin{array}{l}2.5 \\
2.5 \\
2.2 \\
2.0\end{array}$ & $\begin{array}{l}3.7 \\
4.0 \\
3.8 \\
4.0\end{array}$ & $\begin{array}{l}1.7 \\
2.0 \\
2.3 \\
2.7\end{array}$ & $\begin{array}{l}4.2 \\
3.6 \\
3.4 \\
2.8\end{array}$ & $\begin{array}{l}5.9 \\
5.6 \\
5.7 \\
5.5\end{array}$ \\
\hline $\begin{array}{l}40 \\
60 \\
70 \\
80\end{array}$ & 150 & $\begin{array}{l}1.0 \\
1.3 \\
1.5 \\
1.6\end{array}$ & $\begin{array}{l}3.0 \\
2.5 \\
2.4 \\
2.3\end{array}$ & $\begin{array}{l}4.0 \\
3.8 \\
3.9 \\
3.9\end{array}$ & $\begin{array}{l}1.3 \\
1.6 \\
1.7 \\
1.8\end{array}$ & $\begin{array}{l}4.2 \\
4.1 \\
4.1 \\
3.9\end{array}$ & $\begin{array}{l}5.5 \\
5.7 \\
5.8 \\
5.7\end{array}$ \\
\hline $\begin{array}{l}40 \\
60 \\
70 \\
80\end{array}$ & 300 & $\begin{array}{l}1.1 \\
1.3 \\
1.5 \\
1.6\end{array}$ & $\begin{array}{l}2.9 \\
2.9 \\
3.0 \\
2.5\end{array}$ & $\begin{array}{l}4.0 \\
4.2 \\
4.5 \\
4.1\end{array}$ & $\begin{array}{l}0.9 \\
1.2 \\
1.2 \\
1.4\end{array}$ & $\begin{array}{l}4.5 \\
4.3 \\
4.5 \\
4.2\end{array}$ & $\begin{array}{l}5.4 \\
5.5 \\
5.7 \\
5.6\end{array}$ \\
\hline \multicolumn{2}{|c|}{ LSD (0.05) } & 0.6 & 0.8 & 0.8 & 0.7 & 1.2 & 0.9 \\
\hline
\end{tabular}


In both years intercropping showed an advantage over sole cropping when the component densities were high, and in 2003 the lower intercropping densities gave the highest intercropping advantage. Taking the optimal sole crop densities as $100 \%$ (Table 2.1; italicised figures), the highest grain yields in mixture for both years and tillage systems were reached at densities above $100 \%$ of optimal sole crop density.

The means of the total grain yields of all mixtures were not significantly different between the tillage systems, but in 2003 were significantly higher than in $2002(P<0.001)$. Additionally the grain yields of the single components pea and oat did not differ significantly between the tillage systems, with the exception of the grain yields of intercropped oat in 2002. The grain yields of intercropped oat were significantly higher under MT compared to CT $(P<0.01)$.

\subsubsection{Nitrogen content and nitrogen yield}

The grain $\mathrm{N}$ content of pea was not influenced by the different densities, but increased significantly from sole to intercropped pea (Table 2.3) and with increasing oat density. The increase in grain $\mathrm{N}$ content from sole to intercropped pea was higher in 2002 than in 2003 and the grain $\mathrm{N}$ content of intercropped pea was significantly higher in 2002 than in 2003, while that of sole cropped pea did not differ between the years. Therefore interactions between year and crop stand were significant. Grain N content of sole and intercropped pea was significantly higher under MT compared to CT.

The grain $\mathrm{N}$ content of oat also increased significantly through intercropping (Table 2.3), but was not influenced by the different pea densities. For sole cropped oat there was a tendency that an increasing oat density entailed lower grain $\mathrm{N}$ content, which was significant only in the $\mathrm{CT}$ in $2002(P<0.05)$. A negative correlation between grain $\mathrm{N}$ content and grain yield was observed for intercropped oat (CT, 2002: $\mathrm{r}=0.82^{* * *}$; MT, 2002: $\mathrm{r}=-0.62^{*} ; \mathrm{CT}, 2003: \mathrm{r}=$ $-0.89^{* * *} ;$ MT, 2003: $\left.\mathrm{r}=0.96^{* * *}\right)$. CT gave a significantly higher grain $\mathrm{N}$ content of sole and intercropped oat than MT and in 2003 grain N content was higher than in 2002 (Table 2.3). 
Table 2.3

Nitrogen content in the grain (\%) of sole (s) and intercropped (i) pea and oat for the average of all pea and oat densities in conventional (CT) and minimum (MT) tillage systems

\begin{tabular}{|c|c|c|c|c|c|}
\hline \multirow[t]{3}{*}{ Year } & \multirow[t]{3}{*}{ Tillage system } & \multicolumn{4}{|c|}{ Grain N content (\%) } \\
\hline & & \multicolumn{2}{|l|}{ Pea } & \multicolumn{2}{|l|}{ Oat } \\
\hline & & (s) & (i) & (s) & (i) \\
\hline 2002 & $\begin{array}{l}\text { CT } \\
\text { MT }\end{array}$ & $\begin{array}{l}3.23 \\
3.38\end{array}$ & $\begin{array}{l}3.44 \\
3.52\end{array}$ & $\begin{array}{l}1.70 \\
1.65\end{array}$ & $\begin{array}{l}1.95 \\
1.82\end{array}$ \\
\hline 2003 & $\begin{array}{l}\text { CT } \\
\text { MT }\end{array}$ & $\begin{array}{l}3.24 \\
3.33\end{array}$ & $\begin{array}{l}3.32 \\
3.41\end{array}$ & $\begin{array}{l}1.82 \\
1.74\end{array}$ & $\begin{array}{l}2.06 \\
2.01\end{array}$ \\
\hline \multicolumn{2}{|c|}{ Crop stand $^{\mathrm{a}}$} & \multicolumn{2}{|l|}{$\star \star \star *$} & \multicolumn{2}{|l|}{$* \star *$} \\
\hline \multicolumn{2}{|c|}{ Year $^{\mathrm{a}}$} & \multicolumn{2}{|l|}{$\star \star * *$} & \multicolumn{2}{|l|}{$\star * \star$} \\
\hline \multicolumn{2}{|c|}{ Tillage system $^{a}$} & \multicolumn{2}{|l|}{$* * *$} & \multicolumn{2}{|l|}{$* * *$} \\
\hline \multicolumn{2}{|c|}{ 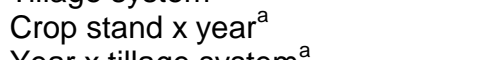 } & \multicolumn{2}{|l|}{ * } & \multicolumn{2}{|l|}{ n.s. } \\
\hline \multicolumn{2}{|c|}{ Year $\mathrm{x}$ tillage system $^{\mathrm{a}}$} & \multirow{2}{*}{\multicolumn{2}{|c|}{$\begin{array}{l}\text { n.s. } \\
\text { n.s. }\end{array}$}} & \multirow{2}{*}{\multicolumn{2}{|c|}{$\begin{array}{l}\text { n.s. } \\
\text { n.s. }\end{array}$}} \\
\hline \multicolumn{2}{|c|}{ Tillage system $x$ crop stand ${ }^{a}$} & & & & \\
\hline
\end{tabular}

Component of variation (Tukey-Test): ${ }^{*, \star \star *}$ significant at $P<0.05,0.001$ levels, respectively; n.s., not significant.

${ }^{a}$ Analyses of variance were done using arithmetical means of all densities of sole and intercropped pea and oat.

The grain $\mathrm{N}$ yield of sole cropped pea, sole cropped oat and intercropped pea and oat was, for the average densities and tillage systems, 107.1, 59.4 and 103.9 $\mathrm{kg} \mathrm{N}^{-1}$ in 2002 and 143.1, 97.5, $140.6 \mathrm{~kg} \mathrm{~N} \mathrm{ha}^{-1}$ in 2003, respectively. The grain $\mathrm{N}$ yield of sole cropped pea was not significantly different from that of intercropped pea and oat, but sole cropped oat always showed significantly lower grain $\mathrm{N}$ yield than sole cropped pea and intercropped pea and oat $(P<$ 0.001 ). There was a tendency for the total grain $\mathrm{N}$ accumulation in intercrops to increase with pea density (Table 2.4), as the effect of pea was greater because of its higher grain $\mathrm{N}$ content. The increased grain $\mathrm{N}$ yield of pea at higher pea densities almost always compensated for the decrease in grain $\mathrm{N}$ yield of oat at lower oat densities. Especially in 2003, the competition of oat at densities above 75 oat seeds $\mathrm{m}^{-2}$ was severe enough to strongly reduce the total amount of grain $\mathrm{N}$ (Table 2.4). There was no significant difference in grain $\mathrm{N}$ yield between the tillage systems, but for both tillage systems total grain $\mathrm{N}$ yield was significantly higher in 2003 than in $2002(P<0.001)$. 
The nitrogen harvest index (NHI) of sole cropped pea, sole cropped oat and the mixtures of pea and oat was, for the average pea and oat densities, 0.68, 0.64 and 0.67 (CT, 2002), 0.69, 0.67 and 0.72 (MT, 2002), 0.83, 0.88 and 0.86 (CT, 2003) and 0.85, 0.89 and 0.87 (MT, 2003), respectively. The NHI was significantly higher in 2003 than in $2002(P<0.001)$ and for sole cropped pea in $2003(P=0.0331)$ and significantly higher in the MT compared to the CT for the mixtures in both years $(P=0.0141$ in 2002 and $P=0.0365$ in 2003). Intercropping increased the NHI of pea, but decreased that of oat. In 2002, the NHI of intercropped pea increased with increasing oat density, while in 2003 the different oat densities did not influence NHI of pea.

Table 2.4

Total amount of nitrogen in grain $\left(\mathrm{kg} \mathrm{N}^{-1}\right)$ accumulated by intercropped pea and oat in various mixture combinations (means for both tillage systems)

\begin{tabular}{|c|c|c|c|c|c|c|c|c|c|c|}
\hline \multirow{2}{*}{$\begin{array}{l}\text { Pea density } \\
\text { (seeds } \mathrm{m}^{-2} \text { ) }\end{array}$} & \multicolumn{5}{|c|}{ 2002: Oat density (seeds $\mathrm{m}^{-2}$ ) } & \multicolumn{5}{|c|}{ 2003: oat density (seeds $\mathrm{m}^{-2}$ ) } \\
\hline & 38 & 75 & 150 & 300 & $\begin{array}{l}\text { Mea } \\
n\end{array}$ & 38 & 75 & 150 & 300 & Mean \\
\hline 40 & 91 & 96 & 92 & 93 & $93 \mathrm{~b}$ & 142 & 146 & 128 & 119 & $134 b$ \\
\hline 60 & 107 & 104 & 99 & 106 & $104 \mathrm{a}$ & 150 & 145 & 137 & 122 & $138 a b$ \\
\hline 70 & 110 & 103 & 104 & 110 & $107 \mathrm{a}$ & 161 & 155 & 142 & 129 & $146 a$ \\
\hline 80 & 107 & 112 & 117 & 110 & $111 \mathrm{a}$ & 153 & 157 & 136 & 129 & $143 a b$ \\
\hline Mean & $104 \mathrm{a}$ & $104 \mathrm{a}$ & $103 a$ & $105 a$ & & $151 \mathrm{a}$ & $151 \mathrm{a}$ & $136 \mathrm{~b}$ & $124 c$ & \\
\hline
\end{tabular}

Means within the densities of the different years followed by the same letter are not significantly different; Tukey's Test $(\alpha=0.05)$.

\subsubsection{Soil N uptake}

The $\mathrm{N}$ derived from soil was 74.6 (2002) and $86.7 \mathrm{~kg} \mathrm{~N} \mathrm{ha}^{-1}$ (2003) by sole cropped pea and 17.2 (2002) and $26.0 \mathrm{~kg} \mathrm{~N} \mathrm{ha}^{-1}$ (2003) by intercropped pea (mean of densities and tillage systems; effect of crop stand $P<0.001$ ). Sole cropped oat accumulated 90.2 (2002) and $110.2 \mathrm{~kg} \mathrm{~N} \mathrm{ha}^{-1}$ (2003) from the soil and intercropped oat 74.5 (2002) and $86.0 \mathrm{~kg} \mathrm{~N} \mathrm{ha}^{-1}$ (2003) (mean of densities and tillage systems; effect of crop stand $P<0.001$ ). The uptake of $\mathrm{N}$ from the soil by intercropped pea and oat together was significantly higher than that of sole cropped pea $(P<0.001)$, but not higher than that of sole cropped oat. The 
uptake of $\mathrm{N}$ from the soil by intercropped oat was lowest when oat was grown at 38 seeds $\mathrm{m}^{-2}$ or pea was grown at 80 seeds $\mathrm{m}^{-2}$ (Figure 2.1, mixture (1) and mixture (3), respectively), but this decrease in soil $\mathrm{N}$ uptake at decreasing oat densities was fully compensated by the soil $\mathrm{N}$ uptake of pea (Figure 2.1). Therefore, uptake of soil $\mathrm{N}$ by intercropped pea and oat was not significantly different between all density combinations in mixture. No significant differences in soil $\mathrm{N}$ uptake of sole or intercropped pea or oat could be detected between the tillage systems, but for all sole and intercropped pea and oat and both tillage systems the uptake of soil $\mathrm{N}$ was significantly higher in 2003 than in $2002(P<0.001)$.

\subsubsection{Symbiotic $\mathrm{N}_{2}$ fixation}

The difference between the weighted $\delta^{15} \mathrm{~N}$ values in the shoot biomass of intercropped pea and oat for the average of all pea and oat densities and years was $4.3 \%$ in the CT and 3.3\% in the MT. Due to the difference in the shoot $\delta^{15} \mathrm{~N}$ value of pea and oat, Ndfa could be estimated using Equation (1). Intercropping increased $\mathrm{Ndfa}$ in the pea shoot biomass significantly in both years and tillage systems independently of mixture composition $(P<0.001)$. Ndfa in the shoot biomass of sole cropped pea in CT and MT was 52.5 and $50.2 \%$ in 2002 and 52.7 and $45.6 \%$ in 2003 and increased when pea was intercropped by 28 and 27 percentage-points in 2002 and by 16 and 20 percentage-points in 2003, respectively. In 2003, when the mineral soil $\mathrm{N}$ content was higher, Ndfa in intercropped pea was significantly lower than in $2002(P<0.001)$ and the increase from sole to intercropped pea was less, while the Ndfa of sole cropped pea was not significantly different between the experimental years. For sole cropped pea in $2003(P=0.0029)$ and intercropped pea in both years $(P=0.0019$ in 2002 and $P=0.0132$ in 2003), there was significantly higher Ndfa in the biomass under CT than MT. 
a)

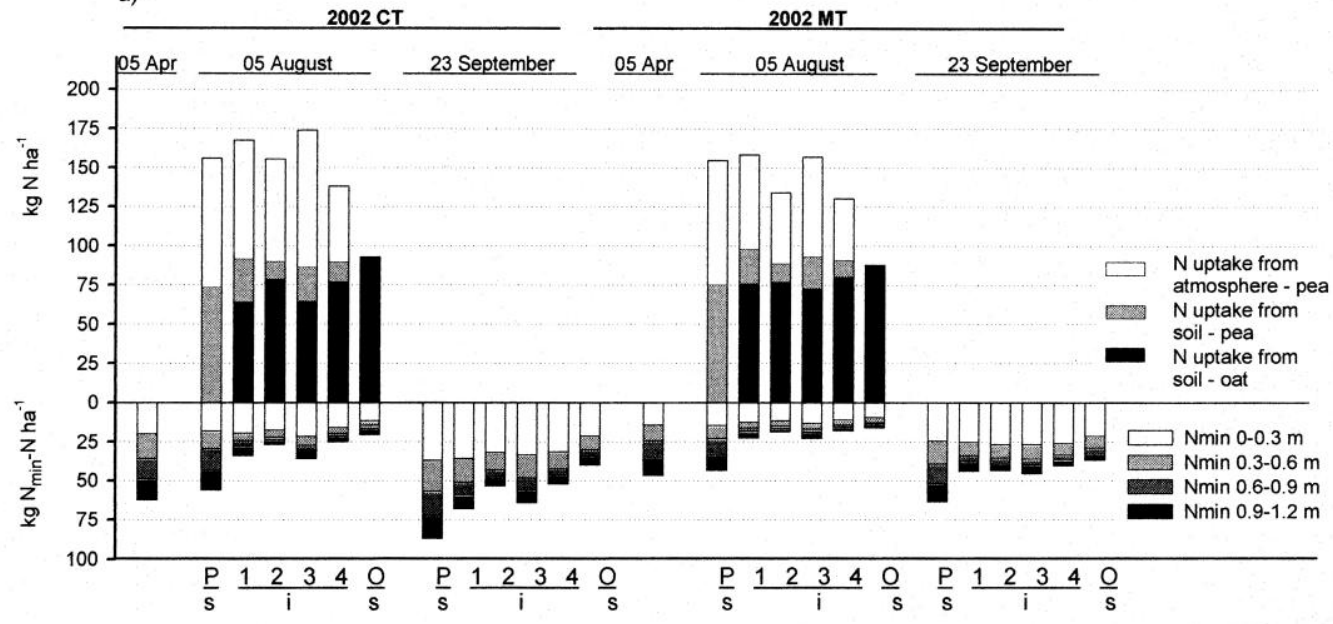

b)

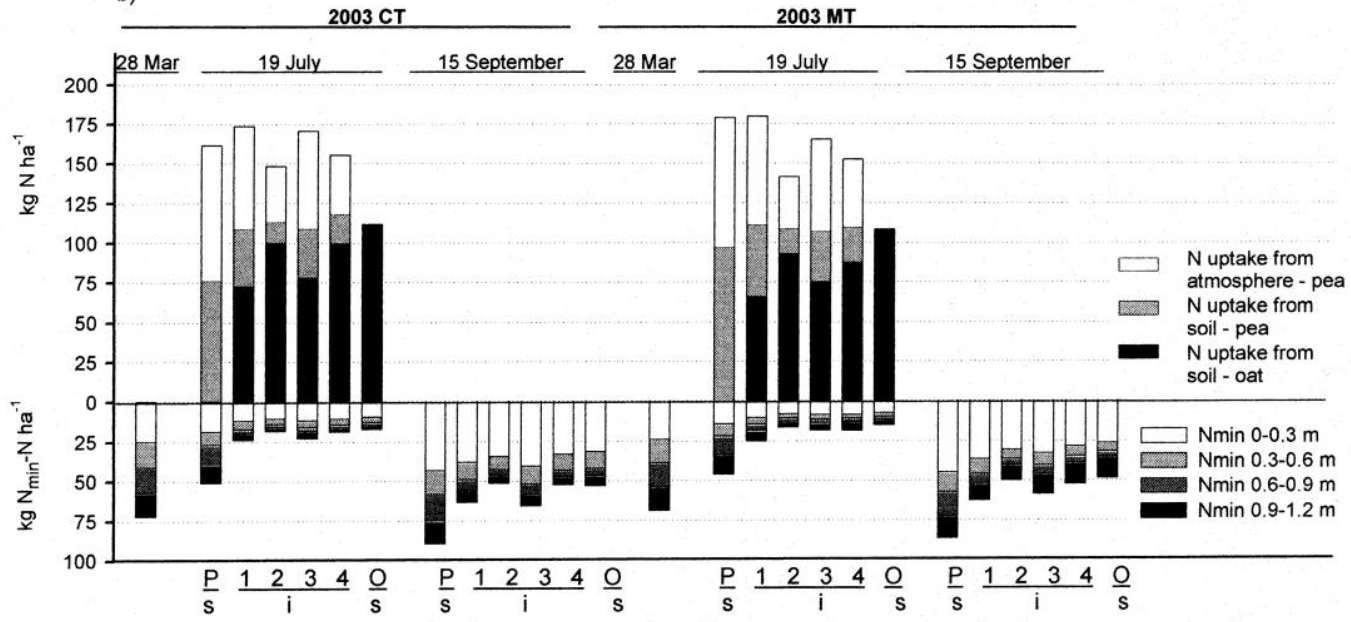

Figure 2.1.

Soil $\mathrm{N}$ and atmospheric $\mathrm{N}_{2}$ accumulation $\left(\mathrm{kg} \mathrm{N}\right.$ ha $\left.^{-1}\right)$ in shoot of pea $(\mathrm{P})$ and oat $(\mathrm{O})$ sole (s) and intercropped (i) in different densities and amount of mineral nitrogen in the soil ( $\mathrm{kg} \mathrm{N}_{\min }-\mathrm{N} \mathrm{ha}^{-1}$ ) at final harvest and three $\mathrm{N}_{\min }-\mathrm{N}$ sampling dates in conventional (CT) and minimum (MT) tillage systems in 2002 (a) and 2003 (b). Mixtures consisted of: (1) 38 oat seeds $\mathrm{m}^{-2}$ intercropped with the mean of all pea densities, (2) 300 oat seeds $\mathrm{m}^{-2}$ intercropped with the mean of all pea densities, (3) 80 pea seeds $\mathrm{m}^{-2}$ intercropped with the mean of all oat densities and (4) 40 pea seeds $\mathrm{m}^{-2}$ intercropped with the mean of all oat seeds; for the sole crops, the means of all pea densities from 40 to 80 seeds $\mathrm{m}^{-2}$ and of all oat densities from 38 to 300 seeds were taken. 
Despite the lower proportion of Ndfa in sole compared to intercropped pea, sole cropped pea always had the highest amounts of symbiotically fixed $\mathrm{N}_{2}$ in the biomass. The amounts of symbiotically fixed $\mathrm{N}_{2}$ in sole cropped pea in CT and MT were 82.4 and $79.4 \mathrm{~kg} \mathrm{~N} \mathrm{ha}^{-1}$ in 2002 and 85.1 and $82.0 \mathrm{~kg} \mathrm{~N} \mathrm{ha}^{-1}$ in 2003 and in intercropped pea 70.5 and $51.2 \mathrm{~kg} \mathrm{~N} \mathrm{ha}^{-1}$ in 2002 and 51.5 and $50.1 \mathrm{~kg} \mathrm{~N}$ $\mathrm{ha}^{-1}$ in 2003 , respectively. While the amount of symbiotically fixed $\mathrm{N}_{2}$ in the biomass of sole cropped pea did not differ significantly between the tillage systems, for intercropped pea significantly higher amounts of symbiotically fixed $\mathrm{N}_{2}$ in the biomass were found in the CT compared with the MT ( $P=$ 0.0006 ; mean of the years). The decrease of the amount of symbiotically fixed $\mathrm{N}_{2}$ in the shoot from sole to intercropped pea was more pronounced in 2003 than in 2002. Total shoot $\mathrm{N}$ derived from atmosphere in intercropped pea increased as pea yield increased, so that mixtures with 80 pea seeds $\mathrm{m}^{-2}$ and 38 oat seeds $\mathrm{m}^{-2}$ yielded the highest amounts of fixed $\mathrm{N}_{2}$ in the above ground biomass (Figure 2.1, mixture (3) and mixture (1), respectively).

\subsubsection{Mineral soil nitrogen}

The total $\mathrm{N}_{\text {min }}-\mathrm{N}$ content in the soil $(0-1.2 \mathrm{~m})$ at the beginning of the growing season was higher in 2003 than in 2002 ( $P=0.0012$; Figure 2.1). In 2002 CT showed significantly higher total $\mathrm{N}_{\min } \mathrm{N}$ contents than MT before sowing $(P<$ $0.05)$, at harvest $(P<0.001)$ and 6 weeks after harvest $(P<0.001)$. In 2003, total $\mathrm{N}_{\min }-\mathrm{N}$ did not differ between the different tillage systems before sowing and 8 weeks after harvest. $\mathrm{N}_{\text {min }}-\mathrm{N}$ contents from 0 to $0.6 \mathrm{~m}$ under $\mathrm{CT}$ were significantly higher than with the MT only at final harvest $(P<0.05)$. In 2002, $\mathrm{N}_{\text {min }}-\mathrm{N}$ beneath sole cropped pea remained nearly unchanged during the vegetation period, while it was significantly reduced in all examined soil layers in 2003. Until final harvest, sole cropped pea reduced the soil $\mathrm{N}_{\min }-\mathrm{N}$ significantly less than intercropped pea and oat and sole cropped oat (Figure 2.1). During the period 6 or 8 weeks after harvest the $\mathrm{N}_{\min }-\mathrm{N}$ content of all soil layers clearly increased after sole cropped pea, and, after sole cropped oat and intercropped pea and oat, increased but to a lower degree, especially in the deeper soil layers. Therefore residual $\mathrm{N}_{\min }-\mathrm{N}$ content in the soil following sole cropped pea was significantly higher than following intercropped pea and oat and sole cropped oat, except in the upper soil layers following the mixtures with 
80 pea seeds $\mathrm{m}^{-2}$ or 38 oat seeds $\mathrm{m}^{-2}$ (Figure 2.1, mixture (3) and mixture (1), respectively).

\subsection{Discussion}

\subsubsection{Competition and grain yield advantage of intercropping}

Increasing the density of sole cropped pea and oat led to increased yields of the sole crops in 2002, so that highest sole crop grain yields were found at highest densities (Table 2.1). However, in 2003, grain yields of the sole crops decreased with increasing density. In 2003 the high $\mathrm{N}_{\min }-\mathrm{N}$ and dry climate conditions led to enhanced growth, especially of sole cropped oat (Figure 2.1), so that intraspecific competition was high, while in 2002 intraspecific competition was low. Intraspecific competition plays an important role not just for sole, but also for intercrops. Willey and Osiru (1972) showed that for mixtures of phaseolus bean (Phaseolus vulgaris L.) and maize intraspecific competition was more important than interspecific competition. This was confirmed by Helenius and Jokinen (1994) with mixtures of faba bean and oat and Bulson et al. (1997) with mixtures of field bean and wheat. Willey (1979) recognized from three different studies, that where intercropping gave an advantage, the total population optimum was higher than that of either sole crop. This was affirmed by the mixtures in this study. Highest grain yields in mixtures were always found at total densities above the optimal sole crop density, which can be traced to higher intraspecific compared with interspecific competition. This means that as, for example, the component oat was more strongly influenced by competition from other oat plants than from pea plants, total density of the mixture could be raised above the optimum sole crop density. On the other hand these results show that the two species were not exactly competing for the same resources and that for mixtures more resources are available than for sole crops.

From the fact, that the decrease in grain yield from sole to intercrop was obviously more severe for pea than for oat it can be concluded that oat was the component which showed higher interspecific competition compared with pea, especially in 2003. For oat, the high inorganic soil N supply in 2003 led to increased uptake of soil $\mathrm{N}$ and enhanced growth. Therefore taller oat plants were produced which competed more than in 2002 for resources with its own as 
well as with the neighbouring species pea. These effects led to reduced N2 fixation and growth of intercropped pea and therefore, to a decreased intercrop advantage. Other studies with mixtures of legumes and nonlegumes also found that a high soil $\mathrm{N}$ supply reduced the intercrop advantage (Andersen et al., 1983; Ofori et al., 1987; Cowell et al., 1989; Jensen, 1996a; Carr et al., 1998; Schmidtke et al., 2004).

\subsubsection{Competition and nitrogen yield advantage of intercropping}

Grain $\mathrm{N}$ yield of intercropped pea and oat was, for all mixtures, advantageously above sole cropped oat. In mixtures with high pea and low oat densities the grain $\mathrm{N}$ yield was even higher than that of sole cropped pea. A trend for intercrops with a high proportion of legumes to accumulate the highest levels nitrogen was already found by Droushiotis (1989), Siri-Udompas and Morris (1990) and Bulson et al. (1997). Andersen et al. (1983) evaluated different pea densities within a replacement series at three different $\mathrm{N}$ levels and not only found the highest grain $\mathrm{N}$ yields at highest pea densities but also observed that $\mathrm{N}$ fertilization reduced the grain $\mathrm{N}$ advantage of the mixture. The effect of $\mathrm{N}$ fertilization was not caused by an influence of $\mathrm{N}$ fertilizer on symbiotic $\mathrm{N}_{2}$ fixation, but by the more vigorous development of the barley crop at the expense of pea growth (Andersen et al., 1983). This can be confirmed by the present study where the different inorganic soil $\mathrm{N}$ content in the years did not influence $\mathrm{N}_{2}$ fixation of sole cropped pea, but intercropping led to a greater reduction of growth and $\mathrm{N}_{2}$ fixation of pea in 2003 when the competitive ability of oat was higher than in 2002 due to higher inorganic soil $\mathrm{N}$ content (Figure 2.1). Therefore, the decreased $\mathrm{N}_{2}$ fixation of intercropped pea at higher inorganic soil $\mathrm{N}$ supply seemed to arise from an indirect effect, i.e. through an increased competitive ability of oat, rather than from a direct effect of the inorganic soil $\mathrm{N}$ supply.

An additional result of the present study was that the $\mathrm{N}$ content in the grain of pea and oat increased from sole to intercrop (Table 2.3). Various other studies have also shown that the $\mathrm{N}$ content of nonlegumes increased when intercropped with legumes (Jensen, 1986; Tofinga et al., 1993; Bulson et al., 1997). Several studies indicated that the increase was due to the transfer of symbiotically fixed nitrogen from the legume to the nonlegume (Eaglesham et al., 1981; Patra et al., 
1986). However, this could not be confirmed by this experiment, as the $\delta^{15} \mathrm{~N}$ values in the shoot biomass of intercropped oat were not lower than the $\delta^{15} \mathrm{~N}$ values in the shoot of sole cropped oat. The grain $\mathrm{N}$ content of intercropped oat increased when grain yield due to interspecific competition decreased. This was shown by the negative correlation of grain yield and grain $\mathrm{N}$ content of intercropped oat. However, this negative correlation was not observed for sole cropped oat. Therefore the increased grain $\mathrm{N}$ content with reduced grain yields seemed to be induced by interspecific competition rather than lower densities.

The increase in the grain $\mathrm{N}$ content of pea in the present study was associated with a decrease in straw-N content, i.e. NHI increased through intercropping. Therefore, the reaction of pea to competition was a change in allocation of $\mathrm{N}$ within the plant. Schmidtke et al. (2004) found for mixtures with lentil (Lens culinaris Medik.) and barley an increase in lentil's NHI occurred only when the competition of barley was low, while strong competition from the barley seemed to curtail lentil's allocation of assimilates to the seeds. In the present experiment, the NHI of pea was also influenced by the strength of competition of oat. In 2002, when the competitiveness of oat was lower than in 2003, increasing the oat density led to an increased NHI for pea, while in 2003, increasing the oat density did not increase NHI any further.

\subsubsection{Competition and soil $\mathrm{N}$ uptake}

The cereal oat, in comparison with pea, is the much stronger competitor in taking $\mathrm{N}$ up from the soil. Consequently the root competition of intercropped oat at high oat densities led to a strongly reduced uptake of soil $\mathrm{N}$ by pea. However the total uptake of soil $\mathrm{N}$ by both pea and oat in mixtures with low oat densities did not differ from the uptake of soil $\mathrm{N}$ by mixtures with higher oat densities or sole cropped oat. This means that pea at high densities not only showed the highest amounts of symbiotically fixed $\mathrm{N}_{2}$ in the shoot, but was also able to compensate for the decreased soil $\mathrm{N}$ uptake by oat at lower oat densities without reducing $\mathrm{N}_{2}$ fixation. Therefore mixture compositions with high pea (70 to 80 seeds $\mathrm{m}^{-2}$ ) and low oat proportions ( 38 to 75 oat seeds $\mathrm{m}^{-2}$ ) gave the highest grain $\mathrm{N}$ yields. The $\mathrm{N}_{\min }-\mathrm{N}$ content of the soil at harvest and the residual $\mathrm{N}_{\text {min }}-\mathrm{N}$ content following these mixtures did not differ from the $\mathrm{N}_{\min }-\mathrm{N}$ content following the mixtures with higher oat densities or sole cropped oat. Especially 
the $\mathrm{N}_{\min }-\mathrm{N}$ content in deeper soil layers under and after all mixture compositions was strongly reduced compared to sole cropped pea. Peas are generally considered to have a relatively shallow rooting depth (Armstrong et al., 1994). The $\mathrm{N}$ sparing effect of pea in deeper soil layers is usually high. Therefore oat must have been responsible for the high level of soil $\mathrm{N}$ uptake in deeper soil layers. Intercropped oat was probably forced to root more deeply, so that soil $\mathrm{N}$ from different layers was used more efficiently by mixtures. This has already been shown to be the case by Hauggaard-Nielsen et al. (2001) for mixtures of pea and barley. Berendse (1982) also reported that differences between the rooting depths of plant species could give relative yield totals which exceed unity. Therefore this effect seems to be another reason for the yield advantage of the mixtures over both sole crops. Additionally, it leads to a reduced risk of nitrogen losses through leaching from deeper soil layers even at high pea and low oat densities (Figure 2.1).

\subsubsection{Influence of tillage systems}

Tillage system had no significant influence on the grain yields of sole and intercropped pea and oat. The differences in grain yield of intercropped oat in 2002 can be traced to an inferior field emergence of oat in the CT compared to the MT due to an unintentionally deeper seed depth in the CT. $\mathrm{N}_{2}$ fixation of sole and intercropped pea was expected to increase under the reduced tillage system, for, as Reiter et al. (2002), long term minimum tillage systems seem to enhance symbiotic $\mathrm{N}_{2}$ fixation. This effect was explained by the lower amount of $\mathrm{N}_{\min }-\mathrm{N}$ content in the soil under the reduced tillage systems, as $\mathrm{N}_{2}$ fixation is typically influenced by inorganic soil $\mathrm{N}$ content (Doran, 1980). However, in the present experiment where no differences in soil $\mathrm{N}$ uptake could be observed, intercropped pea showed higher amounts of fixed $\mathrm{N}_{2}$ in the CT compared with the MT in both experimental years (Figure 2.1). In contrast, this indicates higher competitive ability of pea under CT. Therefore, as the differences between the tillage systems cannot be traced to $\mathrm{N}$ supply and soil $\mathrm{N}$ uptake, probably other soil parameters such as bulk density could have led to a lower competitive ability and decreased $\mathrm{N}_{2}$ fixation of intercropped pea in the mixture in the MT compared with the CT. Unfortunately no measurements of physical soil properties like bulk density or penetration resistance were taken. Also, no statements about soil aeration and soil water content can be made from the 
present experiment. Wright (1989) noted that environmental factors such as precipitation and air temperature could modify crop response to tillage. Wheatley et al. (1995) reported that $\mathrm{N}_{2}$ fixation by soybean increased in tillage treatments which maintained high amounts of residues of the previous crop on the soil surface. This can be explained by the increased soil water content in soils due to being covered by a great amount of stubble (Wheatley et al., 1995). However, in the present study even the dry year 2003 there were no signs of disturbed plant growth through water deficiency, as the experimental site soil has a high water holding capacity and a good ground water connection, so that obviously no water limiting conditions for the plants occurred.

\subsection{Conclusions}

Intercropping of pea and oat can lead to grain yield advantages above sole cropped pea and oat in particular when mixture densities exceed the optimal sole crop density. Therefore, the priority of further intercropping studies should be directed on the analysis of different mixture compositions omitting the replacement design. The mixture combinations which achieved the highest $\mathrm{N}$ use efficiency and therefore intercrop advantage were mainly influenced by inorganic soil $\mathrm{N}$ content at sowing time. With a low inorganic soil $\mathrm{N}$ content, oat can be grown in higher proportions than with a high inorganic soil $\mathrm{N}$ content. The proportion of pea can be high, independently of inorganic soil $\mathrm{N}$ content, as the amount of symbiotically fixed $\mathrm{N}_{2}$ is highest at high densities and soil $\mathrm{N}$ uptake of pea at high densities is able to compensate for the decrease in soil $\mathrm{N}$ uptake of oat at lower densities. In mixed stands even at high pea densities, the risk of $\mathrm{N}$ losses through leaching is substantially reduced in comparison to sole cropped pea. Thus intercropping becomes interesting not only for the potential economic but also for the potential environmental benefits. The influence of tillage system is negligible. 


\section{Acknowledgements}

This study was supported by the German Research Foundation (Deutsche Forschungsgemeinschaft, DFG). We kindly acknowledge the technical assistance of Nina Hoffmann, Christiane Münter, Tomas Brandenburg and Thomas Seibold. Thanks are extended to Reinhard Langel (Competence Centre of Stable Isotopes of the Forest Ecosystems Research Centre, University of Göttingen, Germany) for the $\mathrm{N}$ and ${ }^{15} \mathrm{~N} /{ }^{14} \mathrm{~N}$ analyses. Thanks are also due to Mike Wright for proofreading the English text.

\subsection{References}

Andersen, A.J., Haahr, V., Jensen, E.S., Sandfaer, J., 1983. Effect of N-fertilization on yield, protein content and symbiotic N-fixation in Pisum sativum L. grown in pure stand and mixtures with barley. In Perspectives for Peas and Lupins as Protein Crops. Ed. R Thompson and R Casey. pp. 205-217. Martinus Nijhoff Publishers.

Armstrong, E.L., Pate, J.S., Tennant, D., 1994. The field pea crop in south western Australia Patterns of water use and root growth in genotypes of contrasting morphology and growth habit. Aust. J. Plant Physiol. 21, 517-532.

Begon, M., Townsend, C.R., Harper, J.L., 2006. Ecology: From Individuals to Ecosystems. Blackwell Publishing, 4th edition.

Berendse, F., 1982. Competition between plant populations with different rooting depths. III. Field experiments. Oecologia 53, 50-55.

Bulson, H.A.J., Snaydon, R.W., Stopes, C.E., 1997. Effects of plant density on intercropped wheat and field beans in an organic farming system. J. Agric. Sci., Cambr., 128, 59-71.

Carr, P.M., Gardner, C.G., Schatz, B.G., Zwinger, S.W., Guldan, S.J., 1995. Grain yield and weed biomass of a wheat-lentil intercrop. Agron. J. 87, 574-579.

Carr, P.M., Martin, G.B., Caton, J.S., Poland, W.W., 1998. Forage and nitrogen yield of barleypea and oat-pea intercrops. Agron. J. 90, 79-84.

Cowell, L.E., Bremer, E., Van Kessel, C., 1989. Yield and $\mathrm{N}_{2}$ fixation of pea and lentil as affected by intercropping and N application. Can. J. Soil Sci. 9, 243-251.

Danso, S.K.A., Zapata, F., Hardarson, G. 1987. Nitrogen fixation in fababeans as affected by plant population density in sole or intercropped systems with barley. Soil Biol. Biochem. 19, 411415.

Danso, S.K.A, Hardarson, G., Zapata, F., 1993. Misconceptions and practical problems in the use of ${ }^{15} \mathrm{~N}$ soil enrichment techniques for estimating $\mathrm{N}_{2}$ fixation. Plant Soil 152, 25-52.

Doran, J.W., 1980. Soil microbial and biochemical changes associated with reduced tillage. Soil. Sci. Soc. Am. J. 44, 765-771.

Droushiotis, D.N., 1989. Mixtures of annual legumes and small-grained cereals for forage production under low rainfall. J. Agric. Sci., Cambr. 113, 249-253. 
Eaglesham, A.R.J., Ayanaba, A., Ranga Rao, V., Eskew, D.L., 1981. Short communication. Improving the nitrogen of maize by intercropping with cowpea. Soil Biol. Biochem. 13, 169171.

Hauggaard-Nielsen, H., Jensen, E.S., 2001. Evaluating pea and barley cultivars for complementarity in intercropping at different levels of soil $\mathrm{N}$ availability. Field Crops Res. 72, 185-196.

Hauggaard-Nielsen, H., Ambus, P., Jensen, E.S., 2001. Temporal and spatial distribution of roots and competition for nitrogen in pea-barley intercrops - a field study employing ${ }^{32} \mathrm{P}$ technique. Plant Soil 236, 63-74.

Helenius, J., Jokinen, K., 1994. Yield advantage and competition in intercropped oats (Avena sativa L.) and faba bean (Vicia faba L.): Application of the hyperbolic yield-density model. Field Crops Res. 37, 85-94.

Hoffmann, G., 1991: Die Untersuchung von Böden. VDLUFA-Methodenbuch Band I, VDLUFAVerlag Darmstadt, Germany.

Jensen, E.S., 1986. Symbiotic $\mathrm{N}_{2}$ fixation in pea and field bean estimated by ${ }^{15} \mathrm{~N}$ fertilizer dilution in field experiments with barley as reference crop. Plant Soil 92, 3-13.

Jensen, E.S., 1996a. Grain yield, symbiotic $\mathrm{N}_{2}$ fixation and interspecific competition for inorganic $\mathrm{N}$ in pea-barley intercrops. Plant Soil 182 (1), 25-38.

Jensen, E.S., 1996b. Barley uptake of N deposited in the rizosphere of associated field pea. Soil Biol. Biochem. 28, 159-168.

Jung, R., 2003. Stickstoff-Fixierleistung von Luzerne (Medicago sativa L.), Rotklee (Trifolium pratense L.) und Persischem Klee (Trifolium resupinatum L.) in Reinsaat und Gemenge mit Poaceen. PhD Thesis, University of Göttingen, Germany.

Kessler, W., 1987. Einfluss des Lichtangebotes und der Temperatur auf Ertragsbildung und biologische Stickstoff-Fixierung von Weißklee (Trifolium repens L.). PhD Thesis, ETH Zürich, Switzerland.

Ofori, F., Pate, J.S., Stern, W.R., 1987. Evaluation of $\mathrm{N}_{2}$-fixation and nitrogen economy of a maize/cowpea intercrop system using ${ }^{15} \mathrm{~N}$ dilution methods. Plant Soil 102, 149-160.

Patra, D.D., Sachdev, M.S., Sabhiah, B.V., 1986. ${ }^{15} \mathrm{~N}$ studies on the transfer of legume-fixed nitrogen to associated cereals in intercropping systems. Biol. Fertil. Soils 2, 165-171.

Rauber, R., Schmidtke, K., Kimpel-Freund, H., 2000. Konkurrenz und Ertragsvorteile in Gemengen aus Erbsen (Pisum sativum L.) und Hafer (Avena sativa L.). J. Agron. Crop Sci. 185, 33-47.

Rauber, R., Schmidtke, K., Kimpel-Freund, H., 2001. The performance of pea (Pisum sativum L.) and its role in determining yield advantages in mixed stands of pea an oat (Avena sativa L.). J. Agron. Crop Sci. 187, 137-144.

Reiter, K., Schmidtke, K., Rauber, R., 2002. The influence of long-term tillage systems on symbiotic $\mathrm{N}_{2}$ fixation of pea (Pisum sativum $\mathrm{L}$.) and red clover (Trifolium pratense L.). Plant Soil 238, 41-55.

Schmidtke, K., Neumann, A., Hof, C., Rauber, R., 2004. Soil and atmospheric nitrogen uptake by lentil (Lens culinaris Medik.) and barley (Hordeum vulgare ssp. nudum L.) as monocrops and intercrops. Field Crops Res. 87, 245-256.

Shearer, G., Kohl, D.H., 1986. $\mathrm{N}_{2}$-fixation in field settings: estimations based on natural ${ }^{15} \mathrm{~N}$ abundance. Aust. J. Plant Physiol. 13, 699-756. 
Siri-Udompas, C., Morris, R.A., 1990. Effects of crop proportion on intercropped upland rice and cowpea. 2. Nitrogen yields. Field Crops Res. 25, 233-246.

Stratmann, R., Menz, M., Schraa, M., 2004. ZMP-Marktbilanz Getreide · Ölsaaten · Futtermittel 2004. Zentrale Markt- und Preisberichtstelle GmbH, Bonn.

Tofinga, M.P., Snaydon, R.W., 1992. The root activity of cereals and peas when grown in pure stands and mixtures. Plant Soil 142, 281-285.

Tofinga, M.P., Paolini, R., Snaydon, R.W., 1993. A study of root and shoot interactions between cereals and peas in mixture. J. Agric. Sci. 120, 13-24.

Wheatley, D.M., Macleod, D.A., Jessop, R.S., 1995. Influence of tillage treatment on $\mathrm{N}_{2}$ fixation of soybean. Soil Biol. Biochem. 27, 571-574.

Willey, R.W., Osiru, D.S.O., 1972. Studies on mixtures of maize and beans (Phaseolus vulgaris) with particular reference to plant population. J. Agric. Sci., Camb., 79, 517-529.

Willey, R.W., 1979. Intercropping - Its importance and research needs. Part 1. Competition and yield advantages. Field Crop Abstr. 32, 2-10.

Wilson, J.B., 1988. Shoot and root competition. J. Appl. Ecology 25, 279-296.

Wright, A.T., 1989. Seedbed preparation for rapeseed grown on fallow and stubble. Can. J. Plant Sci. 69, 805-814.

Yunusa, I.A.M., 1989. Effects of planting density and plant arrangement pattern on growth and yields of maize (Zea mays L.) and soya bean (Glycine $\max$ (L.) Merr.) grown in mixtures. J. Agric. Sci., Camb. 112, 1-8. 



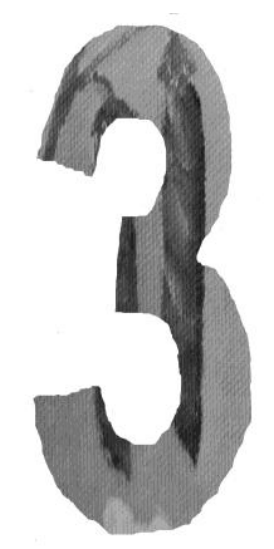

\title{
Evaluation of yield-density relationships and optimization of intercrop compositions of field-grown pea-oat intercrops using the replacement series and the response surface design
}

\author{
Angelika Neumann, Jochen Werner, Rolf Rauber (2009) \\ Field Crops Research 114, 286-294 \\ gedruckt mit Genehmigung von Elsevier
}

\subsection{Abstract}

In a 2-year field experiment (2002/2003) on a loess soil near Göttingen/ Germany, pea (Pisum sativum L.) and oat (Avena sativa L.) were grown alone and intercropped at a range of densities. Shoot biomass, grain yields and amount of $\mathrm{N}$ in grain were evaluated and optimized using two different replacement series and a hyperbolic yield-density equation describing a response surface to address the following questions: (i) what is the optimal composition of the pea-oat intercrop with regard to maximum yields, (ii) which intercropping design is most suitable to describe competition effects in pea-oat intercrops and the optimal intercrop compositions and (iii) which intercropping design is best suited for the evaluation of field data. For (i), the optimal intercrop compositions varied depending on the growth conditions for the crops. 
Furthermore, optimal intercrop compositions were found above the recommended sole crop densities. The density of oat had to be reduced more than that of pea, especially when optimal grain-N yields were desired and soil-N content was high. For maximum grain-N yields, pea could be sown at high densities in combination with $5-50 \%$ of the recommended density of oat. Thus, density can be used as a yield regulator for specific purposes such as a high $\mathrm{N}$ yield. The effects of competition at final harvest were described equally by both designs (ii). Oat was the clearly stronger and pea the inferior competitor. In contrast to the replacement series design, the hyperbolic yield-density equation was capable of adding valuable information about the extent of intra and interspecific competition. As intraspecific competition was consistently more important than interspecific competition, resource complementarity could be hold responsible for intercrop advantages. The highest intercrop advantage was found when total intraspecific competition was low, as shown by the relative yield total (RYT) and niche differentiation index (NDI) values $>1$. However, due to the RYT dependence on sole crops and total densities, the replacement series design led to misleading interpretations of the yield advantages. Both experimental designs were able to describe the field-data reliably (iii), but the response surface design had the advantage of being unaffected by insufficient field emergences, as it is not based on total densities. Numbers of plants $\mathrm{m}^{-2}$ instead of seeds $\mathrm{m}^{-2}$ can be used for the evaluation. Data from sole crops are not needed for the response surface design and thus the feared high experimental effort of this design can be reduced. However, when using the replacement series design, experimental effort should be greater than normal, as different sole crop densities and more intercrop compositions within a replacement series can lead to a more precise interpretation of the competition effects. 


\subsection{Introduction}

The cultivation of two different plant species in one field is attracting increasing interest in developed countries as it can provide increased yields in an environmentally sustainable manner (Park et al., 2002; Gliessman, 2007). Many intercropping experiments are intended to find intercrop compositions that yield better than sole crops, although there are several other reasons why intercropping is practised (Spitters, 1983). This search for optimal intercrop compositions, and consequently a better understanding of competition effects, has already occupied scientists for decades. Different experimental designs and evaluation methods were established to investigate competition between species and to find optimal densities for achieving maximum intercrop yields. The discussions about which design is to prefer are numerous, but they are often based on theoretical approaches (e.g. Trenbath, 1978; Connolly, 1987; Cousens, 1991; Snaydon, 1991; Sackville Hamilton, 1994; Jolliffe, 2000). The aim of the present study is to compare the results of two different experimental designs, the replacement series design and the response surface design, on the basis of field data and therewith contribute to the discussion. The replacement series design, which holds the total density constant while varying the relative proportion of the intercropped species was introduced by De Wit (1960) and is the most common used design. Nevertheless it is often criticized as it is based on the comparison of intercrops and sole crops and therefore does not allow the separation of intra and interspecific competition (Jolliffe et al., 1984). Additionally, if inappropriate sole crop densities are chosen, resulting conclusions may be misleading (Law and Watkinson, 1987). Therefore two different sole crop densities were examined in the present experiment. The response surface design, which varies the densities of both species independently, is less frequently used as the mathematical description of the subsequently emerging three-dimensional surface is challenging. Various equations have already been examined to describe the relationship between the densities of two species (Inouye, 2001), but with increasing numbers of coefficients and mathematical operations doubts about their validity increases (Weigelt and Jolliffe, 2003). In the present study a hyperbolic yield-density equation first described by Wright (1981) was chosen. Cousens (1985) found that this equation provided the most adequate description of both grain and biomass yields of intercropped wheat and barley, while other 
more elaborate models were not justified. The equation describes yield-density relationships with two variables and three coefficients, which can be easily interpreted to gain valuable knowledge about competition effects (Spitters, 1983). In addition, the present study introduces an optimization of the equation from Wright (1981) to calculate absolute optimal densities.

Different yield parameters were investigated. As dry-matter distribution within plants varies with competitive stress, shoot biomass was seen as the best factor to measure interplant competition (Spitters, 1983). Additionally, optimal grain yields should be found as grain is the harvestable product. Due to rising prices for nitrogen fertilizer and protein fodder as well as the decreased availability of GMO-free protein sources, our analysis emphasizes $\mathrm{N}$ yields in grain. The yield parameters for field-grown pea (Pisum sativum L.) and oat (Avena sativa L.) were evaluated using two different replacement series and a yield-density equation within the response surface design to address the following questions: (i) what is the optimal composition of the pea-oat intercrop with regard to maximum yields, (ii) which intercropping design is most suitable to describe competition effects in pea-oat intercrops and optimal intercrop compositions and (iii) which intercropping design is best suited for the evaluation of field data.

\subsection{Material and Methods}

\subsubsection{Soil and growing conditions}

The field experiments were conducted in 2002 and 2003 on a loess soil (Fluventic Eutrochrept) near Göttingen ( $51^{\circ} 32^{\prime}$ N, $9^{\circ} 56^{\prime}$ E), Germany. The topsoil $(0-0.3 \mathrm{~m})$ of the experimental field was a silty loam with a proportion of 0.178 clay, 0.683 silt and 0.139 sand (Jung, 2003). For further information about the soil see Neumann et al. (2007).

The annual precipitation at Göttingen (long-term average 1961 - 1990) is 648 $\mathrm{mm}$, almost regularly distributed throughout the year. The experimental site is part of the cool-temperate zone, characterized by a sub-oceanic climate with warm summers and an annual mean long-term average temperature of $8.7^{\circ} \mathrm{C}$. From April until the end of July the long-term average temperature is $13.4{ }^{\circ} \mathrm{C}$ and precipitation is $253 \mathrm{~mm}$. In the experimental years these values were $13.9{ }^{\circ} \mathrm{C}(2002) / 14.8{ }^{\circ} \mathrm{C}(2003)$ and $338 \mathrm{~mm}$ (2002) / $185 \mathrm{~mm}$ (2003). The pre- 
cipitation of both years differed considerable from the long-term average. In 2002, especially during the months May and July precipitation above the longterm average was apparent, while in 2003, precipitation was below long-term average for every month.

The preceding crop was summer barley (Hordeum vulgare L.) fertilized with 70 $\mathrm{kg} \mathrm{N} \mathrm{ha}^{-1}$. The barley straw was chopped finely and remained on the field. After the harvest of barley in 2001 and 2002, the stubble was cultivated with a rotary harrow. Plots were ploughed in late autumn. During the experiment no fertilizer was applied. Weeds and pests were controlled with appropriate pesticides.

\subsubsection{Field design}

The field trial was arranged in a randomized block design with four replicates each year. The mixtures were grown in alternate rows. Row spacing of sole crops and mixtures was $0.122 \mathrm{~m}$; therefore the distance between the same species in mixture was $0.244 \mathrm{~m}$. A subplot consisted of 10 rows each $7.8 \mathrm{~m}$ long, so that the size of a subplot was $9.5 \mathrm{~m}^{2}$. Pea (cv. Classic) was sown at densities of 40, 60, 70, 80 and 120 seeds $\mathrm{m}^{-2}$ and oat (cv. Alf) at densities of 38, 75, 150, 300 and 450 seeds $\mathrm{m}^{-2}$ as sole crops and in mixtures. The mixtures consisted of all density combinations of pea from 40 to 80 seeds $\mathrm{m}^{-2}$ and oat from 38 to 300 seeds $\mathrm{m}^{-2}$ giving 16 combinations of mixtures in total.

\subsubsection{Sampling procedure and analysis}

After seedling emergence, harvest plots (six rows at a length of $2 \mathrm{~m}$; harvest plot size $1.464 \mathrm{~m}^{2}$ ) were marked and one week after seedling emergence the seedlings were counted to determine the numbers of plants $\mathrm{m}^{-2}$ and the field emergence. Plants were harvested at the maturity of both pea and oat (sole cropped pea: 30 July 2002, sole cropped oat and mixtures: 5 August 2002, all sole crops and mixtures: 19 July 2003). Harvested shoot biomass, separated in grain and straw, was dried to a constant weight at $60^{\circ} \mathrm{C}$. The dried biomass was milled to fine powder with a particle size $<0.2 \mathrm{~mm}$ (Retsch ZM 100). Analyses of total $\mathrm{N}$ content were carried out using an isotope ratio mass spectrometer (Finnigan MAT 251). 
Immediately after sowing and after the harvest, the mineral nitrogen $\left(\mathrm{N}_{\min }-\mathrm{N}=\right.$ $\mathrm{NO}_{3}-\mathrm{N}+\mathrm{NH}_{4}-\mathrm{N}$; from 0 to $1.20 \mathrm{~m}$ depth, four equal horizontal sections) was extracted from the soil using $0.01 \mathrm{M}$ of $\mathrm{CaCl}_{2}$. Nitrate and ammonium were quantified using a Perstorp analytical auto analyser (Flow Solution III). The soil samples were taken with a soil core sampling set (four soil cores from each plot with a diameter of $17 \mathrm{~mm}$ ), immediately homogenized and then frozen for further evaluation.

\subsubsection{Evaluation and optimization using the replacement series design}

Two different replacement series were planted. Replacement series 1 (RS 1) was based on the recommended sole crop densities of pea $\left(80\right.$ seeds $\left.\mathrm{m}^{-2}\right)$ and oat (300 seeds $\mathrm{m}^{-2}$ ). It consisted of three different mixtures with relative density proportions of pea to oat $87.5 \%: 12.5 \%, 75 \%: 25 \%$ and 50\%:50\%. For replacement series 2 (RS 2) sole crop densities above the recommended sole crop densities of pea $\left(120\right.$ seeds $\left.\mathrm{m}^{-2}\right)$ and oat $\left(450\right.$ seeds $\left.\mathrm{m}^{-2}\right)$ were used, with two different mixtures with the relative density proportions of pea to oat $67 \%: 33 \%$ and $33 \%: 67 \%$.

For analysis, we used regressions of the yields of intercropped pea $\left(\mathrm{Y}_{\mathrm{po}}\right)$ and oat $\left(\mathrm{Y}_{\mathrm{op}}\right)$ to the equations

$$
\begin{aligned}
& Y_{p o}=\frac{\left(k_{p o} r_{p o}\right)}{\left(1-r_{p o}\right)+k_{p o} r_{p o}} Y_{p p} \text { and } \\
& Y_{o p}=\frac{\left(k_{o p} r_{o p}\right)}{\left(1-r_{o p}\right)+k_{o p} r_{o p}} Y_{o o},
\end{aligned}
$$

where $Y_{p p}$ and $Y_{o o}$ are the yields of sole cropped pea and oat, $r_{p o}$ and $r_{o p}$ the relative densities of intercropped pea and oat and $\mathrm{k}_{\mathrm{po}}$ and $\mathrm{k}_{\mathrm{op}}$ are constants, which describe the competitive ability of intercropped pea and oat and were introduced by De Wit (1960) as crowding coefficients. The regressions using arithmetical means of the yields were done using Statistica (Version 8; StatSoft, 2007).

Optimizations of equations (1a) and (1b) to find maximum intercrop yields and optimal relative densities for intercropped pea and oat were described by Van den Bergh (1968). A commonly used parameter to measure the superiority of 
intercrops above sole crops is the Relative Yield Total (RYT). In the present study RYT was calculated for the maximum yields $\left(\mathrm{RYT}_{\max }\right)$ with the equation

$$
R T_{\max }=\frac{Y_{p o}^{*}}{Y_{p p}}+\frac{Y_{o p}^{*}}{Y_{o o}},
$$

where $\mathrm{Y}_{\mathrm{po}}{ }^{*}$ and $\mathrm{Y}_{\mathrm{op}}{ }^{*}$ are the maximum yields of intercropped pea and oat, respectively.

\subsubsection{Evaluation and optimization using the response surface design}

For the analysis of the response surface consisting of the 16 examined intercrop combinations an extension of the simple reciprocal relationship

$\mathrm{w}_{\mathrm{pp}}{ }^{-1}=\mathrm{b}_{0}+\mathrm{b}_{1} \mathrm{~d}_{\mathrm{pp}}$ and

$\mathrm{w}_{\mathrm{oO}}{ }^{-1}=\mathrm{c}_{0}+\mathrm{c}_{1} \mathrm{~d}_{\mathrm{oo}}$

for monocultures of pea $\left({ }_{\mathrm{pp}}\right)$ and oat $\left(_{\mathrm{oo}}\right)$ of Wright (1981) to

$w_{p o}^{-1}=b_{0}+b_{1} d_{p o}+b_{2} d_{o p}$ and

$\mathrm{w}_{\mathrm{op}}^{-1}=\mathrm{c}_{0}+\mathrm{c}_{1} \mathrm{~d}_{\mathrm{op}}+\mathrm{c}_{2} \mathrm{~d}_{\mathrm{po}}$

was used for the binary mixtures of intercropped pea (po) and oat $\left(_{\mathrm{op}}\right)$, where $\mathrm{w}$ is the mean weight per plant, $d$ the absolute density of the intercropped plants and $\mathrm{b}_{0}, \mathrm{~b}_{1}, \mathrm{~b}_{2}, \mathrm{c}_{0}, \mathrm{c}_{1}$ and $\mathrm{c}_{2}$ are constants. $\mathrm{b}_{0}$ and $\mathrm{c}_{0}$ denote the asymptotic reciprocal yield of an isolated plant without the influence of competition. $b_{1}$ and $c_{1}$ describe the effect of increasing density of pea or oat plants on the weights of the same species (intraspecific competition), while $b_{2}$ and $c_{2}$ describe the effect of increasing density of pea or oat plants on the weights of the other species (interspecific competition). For the independent variable density (d), the number of plants $\mathrm{m}^{-2}$ was used. The dependent variables per-plant weights $(\mathrm{w})$ were the shoot biomass and grain yield (g DM) and the nitrogen yield in the grain ( $\mathrm{g}$ $\mathrm{N})$ per plant. As per-plant weights vary considerably among species and yield parameters, constants are weighted by the asymptotic per-plant weight $\left(b_{1} / b_{0}\right.$, $\left.\mathrm{b}_{2} / \mathrm{b}_{0}, \mathrm{c}_{1} / \mathrm{c}_{0}, \mathrm{c}_{2} / \mathrm{c}_{0}\right)$. These ratios express the increases in $\mathrm{w}^{-1}$ and hence the decrease in per-plant weight with any plant added to the population relative to its value without competition, thus they are used as a measure for intra and interspecific stress (Spitters, 1983). As well as estimating intra and interspecific 
competitive stress, the coefficients are used for calculating additional biological factors: The ratios $b_{1} / b_{2}$ and $c_{1} / c_{2}$ show the relationship between intra and interspecific competition. If for example, $b_{1} / b_{2}$ equals 4 , one pea plant and 4 oat plants have the same influence on the per-plant weight of pea. Hence, the addition of any extra pea plant to the intercrop reduces the per-plant weight of pea to the same extent as the addition of 4 oat plants. Therefore the ratios $b_{1} / b_{2}$ and $\mathrm{c}_{1} / \mathrm{c}_{2}$ are seen as a measurement of the relative competitive ability (RC; Helenius and Jokinen, 1994). Resource partitioning is analysed by using the double ratio $\left(b_{1} / b_{2}\right) /\left(c_{2} / c_{1}\right)$, known as Niche Differentiation Index (NDI), which ranks the relative strengths of intraspecific and interspecific competition (Spitters, 1983). Values for NDI $>1$ show that species are only partly limited by the same resource; they partly avoid each other. The NDI for the response surface design is therefore analogous to the RYT for the replacement series design. The yielddensity equation was fitted to the data from individual plot measurements instead of arithmetical means using the software Statistica (Version 8; StatSoft, 2007). The normality of the data was tested using the Shapiro-Wilk test.

The total yield $(\mathrm{Y})$ of the mixture at a certain pea $\left(\mathrm{d}_{\mathrm{po}}\right)$ and oat density $\left(\mathrm{d}_{\mathrm{op}}\right)$ can be described with the following hyperbolic yield-density equation as

$$
Y\left(d_{p o}, d_{o p}\right)=\frac{d_{p o}}{b_{0}+b_{1} d_{p o}+b_{2} d_{o p}}+\frac{d_{o p}}{c_{0}+c_{1} d_{o p}+c_{2} d_{p o}} .
$$

To find the maximum total yield, the equation (3c) was optimized within the rectangular $\left[1_{p}, u_{p}\right] \times\left[1_{o}, u_{o}\right]$, where $1_{p}$ is the lowest and $u_{p}$ the highest examined density of pea and $l_{o}$ the lowest and $u_{o}$ the highest examined density of oat. The optimization was done using the mathematical software Mathematica (Version 5; Wolfram, 2003).

The gradient of the function $\mathrm{Y}$ vanishes at $\left(\mathrm{d}_{\mathrm{po}}{ }^{*}, \mathrm{~d}_{\mathrm{op}}{ }^{*}\right)$, where

$d_{p o}{ }^{*}=-c_{0}\left(b_{2} c_{0}-b_{0} c_{1}\right)^{2} f^{-1}$ and

$d_{o p}{ }^{*}=b_{0}\left(b_{1} c_{0}-b_{0} c_{2}\right)^{2} f^{-1}$

with $f=-b_{1}{ }^{2} b_{2} c_{0}{ }^{2}+2 b_{0} b_{1} b_{2} c_{0} c_{2}+c_{2}\left[b_{2}{ }^{2} c_{0}^{2}+b_{0}{ }^{2} c_{1}{ }^{2}+b_{0} b_{2}\left(2 c_{0} c_{1}+b_{0} c_{2}\right)\right]$. 
The associated value of $\mathrm{Y}$ is given by

$$
\mathrm{Y}^{*}\left(\mathrm{~d}_{\mathrm{po}}{ }^{*}, \mathrm{dop}_{\mathrm{op}}{ }^{*}\right)=\frac{\mathrm{b}_{2} \mathrm{c}_{0}{ }^{2}-\mathrm{b}_{0} \mathrm{c}_{0}\left(\mathrm{~b}_{1}+\mathrm{c}_{1}\right)+\mathrm{b}_{0}{ }^{2} \mathrm{c}_{2}}{\left(\mathrm{~b}_{2} \mathrm{C}_{0}-\mathrm{b}_{0} \mathrm{c}_{1}\right)\left(\mathrm{b}_{1} \mathrm{c}_{0}-\mathrm{b}_{0} \mathrm{c}_{2}\right)} .
$$

The determinant of the Hessian of $\mathrm{Y}$ at $\left(\mathrm{d}_{\mathrm{po}}{ }^{*}, \mathrm{~d}_{\mathrm{op}}{ }^{*}\right)$ is given by

$\operatorname{det}\left(\nabla^{2} Y^{*}\left(d_{p o}{ }^{*}, d_{o p}{ }^{*}\right)\right)=-f^{6} /\left[\left(b_{2} c_{0}-b_{0} c_{1}\right)^{8}\left(b_{1} c_{0}-b_{0} c_{2}\right)^{8}\right]$.

From this, it can be concluded that one eigenvalue of the Hessian is negative and the other is positive. Thus the function Y possesses neither a local maximum nor a local minimum in the interior of the given rectangle. That means it will suffice to solve the four one-dimensional optimizations:

1. Optimize $Y\left(I_{p}, \cdot\right)$ on $\left[l_{o}, u_{o}\right]$

2. Optimize $Y\left(u_{p}, \cdot\right)$ on $\left[l_{0}, u_{o}\right]$

3. Optimize $Y\left(\cdot, I_{0}\right)$ on $\left[I_{p}, u_{p}\right]$

4. Optimize $Y\left(\cdot, u_{o}\right)$ on $\left[l_{p}, u_{p}\right]$.

\subsubsection{Statistical Analysis}

The general linear model (GLM) of the statistical analysis system software (SAS) was used to analyse the variance (Version 8.1; SAS Institute, 2000). Normal distribution within the system was tested using the UNIVARIATE NORMAL procedure. All statistical analyses were done within individual procedures using arithmetical means of the original data. 


\subsection{Results}

Although the primary purpose of this paper was to evaluate the interpretation and optimization of the different experimental designs, some field data are shown as preliminary results to enable a later comparison with the interpretations of model coefficients and to draw inferences from field conditions.

\subsubsection{Field data}

Due to damage from slugs and mice, field emergence did not reach $100 \%$ in either year. Averaged over all densities, in mixture 83\% (2002) and 74\% (2003) of the pea seeds and 76\% (2002 and 2003) of the oat seeds emerged, and in the sole crops $78 \%$ (2002) and 74\% (2003) of the pea seeds and 77\% (2002) and $80 \%$ (2003) of the oat seeds emerged. Mineral soil-N content $\left(\mathrm{N}_{\min }\right)$ in the layer from 0 to $1.2 \mathrm{~m}$ at the time of sowing was $62.5 \mathrm{~kg} \mathrm{ha}^{-1}$ in 2002 and $72.2 \mathrm{~kg} \mathrm{ha}^{-1}$ in 2003 and therefore was significantly lower in 2002 compared to 2003 ( $P=$ 0.0012). Averaged over mixture subplots, $\mathrm{N}_{\min }$ was $30.6 \mathrm{~kg}$ (2002) and $20.5 \mathrm{~kg}$ (2003) at harvest. Thus, the difference in $\mathrm{N}_{\min }$ content from sowing to harvest for intercrops was significantly lower in $2002(31.9 \mathrm{~kg})$ than in $2003(51.7 \mathrm{~kg})$ $(P<0.001) . \mathrm{N}_{\min }$ values for sole cropped oat were $20.6 \mathrm{~kg}(2002)$ and $17.3 \mathrm{~kg}$ (2003) at harvest, while sole cropped pea left $56.0 \mathrm{~kg} \mathrm{~N}$ min $(2002)$ and $51.4 \mathrm{~kg}$ $\mathrm{N}_{\text {min }}$ (2003). From sowing to final harvest, the difference in $\mathrm{N}_{\min }$ content was 6.5 $\mathrm{kg}$ in 2002 and $20.8 \mathrm{~kg}$ in 2003 for sole cropped pea, and in both years was significantly lower than that of sole cropped oat and the mixtures $(P<0.001)$.

Total shoot biomass yield of the mixtures averaged over all pea and oat densities was $9.0 \mathrm{Mg} \mathrm{ha}^{-1}$ in 2002 and $10.5 \mathrm{Mg} \mathrm{ha}^{-1}$ in 2003 and was significantly higher in 2003 than in $2002(P<0.001$; Table 3.1).

The increase in shoot yield from 2002 to 2003 can be fully ascribed to the increased growth of intercropped oat in 2003, while intercropped pea showed lower growth in 2003 compared to 2002. This lower growth of intercropped pea in 2003 can only partly be traced back to competition by oat, as sole cropped pea also did not show significant differences between the years. This shows that growth conditions for oat were more favourable in 2003 than in 2002, which could very likely be caused by the higher soil-N content in 2003. Sole and intercropped pea did not benefit from these growth conditions, possibly due to low 
precipitation in 2003. For grain yields and amount of $\mathrm{N}$ in grain of intercropped oat, the sum of the intercrops and both sole crops yields were also significantly lower in 2002 compared to 2003 ( $P<0.001$; Table 3.1), while no significant differences between the years could be found for intercropped pea. Both sole crops as well as intercropped oat seemed to benefit from the increased soil-N level in 2003, while intercropped pea in mixture did not react with increased grain and grain-N yields to the increased soil-N level.

Table 3.1

Shoot and grain yields as well as amounts of $N$ in grain of sole cropped pea $\left(P_{s}\right)$ and oat $\left(\mathrm{O}_{\mathrm{s}}\right)$, intercropped pea $\left(\mathrm{P}_{\mathrm{i}}\right)$ and oat $\left(\mathrm{O}_{\mathrm{i}}\right)$ and the sum of intercropped pea and oat $\left(\mathrm{P}_{\mathrm{i}}+\mathrm{O}_{\mathrm{i}}\right)$ in the means of all densities from 40 to 80 pea seeds $\mathrm{m}^{-2}$ and 38 to 300 oat seeds $\mathrm{m}^{-2}$

\begin{tabular}{|c|c|c|c|c|c|c|c|c|c|}
\hline \multirow[b]{3}{*}{$\mathrm{P}$} & \multicolumn{3}{|c|}{$\begin{array}{c}\text { Shoot } \\
\left(\mathrm{Mg} \mathrm{DM} \mathrm{ha}^{-1}\right)\end{array}$} & \multicolumn{2}{|c|}{$\begin{array}{c}\text { Grain } \\
\left(\mathrm{Mg} \mathrm{DM} \mathrm{ha}^{-1}\right)\end{array}$} & & \multicolumn{3}{|c|}{$\begin{array}{l}\mathrm{N} \text { in grain } \\
\left(\mathrm{kg} \mathrm{N} \mathrm{ha}^{-1}\right)\end{array}$} \\
\hline & 2002 & 2003 & & 2002 & 2003 & & 2002 & 2003 & \\
\hline & 7.1 & 7.5 & ns & 3.2 & 4.0 & $* *$ & 106.1 & 133.8 & **夫 \\
\hline $\mathrm{O}_{\mathrm{s}}$ & 7.9 & 10.0 & $\star * *$ & 3.4 & 5.4 & $* \star \star$ & 60.0 & 98.6 & $* * *$ \\
\hline$P_{i}$ & 3.8 & 3.5 & ** & 1.8 & 1.8 & ns & 64.4 & 63.4 & ns \\
\hline $\mathrm{O}_{\mathrm{i}}$ & 5.2 & 7.0 & $* * *$ & 2.1 & 3.7 & & 41.6 & 77.9 & 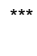 \\
\hline$P_{i}+O_{i}$ & 9.0 & 10.5 & $* \star \star$ & 3.9 & 5.6 & ${ }^{* \star \star}$ & 110.0 & 141.3 & *** \\
\hline LSD (0.05) & 1.2 & 1.1 & & 0.6 & 0.7 & & 16.0 & 17.4 & \\
\hline
\end{tabular}

Component of variation between the years (Tukey's test): ${ }^{* * * * *}$ significant at $P<0.01,0.001$ levels, respectively; ${ }^{\text {ns }}$ not significant

The increase in shoot yield from 2002 to 2003 can be fully ascribed to the increased growth of intercropped oat in 2003, while intercropped pea showed lower growth in 2003 compared to 2002. This lower growth of intercropped pea in 2003 can only partly be traced back to competition by oat, as sole cropped pea also did not show significant differences between the years. This shows that growth conditions for oat were more favourable in 2003 than in 2002, which could very likely be caused by the higher soil-N content in 2003. Sole and intercropped pea did not benefit from these growth conditions, possibly due to low precipitation in 2003. For grain yields and amount of $\mathrm{N}$ in grain of intercropped oat, the sum of the intercrops and both sole crops yields were also significantly lower in 2002 compared to 2003 ( $P<0.001$; Table 3.1), while no significant 
differences between the years could be found for intercropped pea. Both sole crops as well as intercropped oat seemed to benefit from the increased soil-N level in 2003, while intercropped pea in mixture did not react with increased grain and grain-N yields to the increased soil-N level.

\subsubsection{Replacement series}

Even though actual densities differed considerably from targeted densities, regressions for the equations (1a) and (1b) had to be done using the targeted densities. However, the equations describe the reaction of pea and oat on density very precise (Table 3.2 and 3.3).

Table 3.2

Regression coefficients $(r)$ and crowding coefficients $\left(k_{p o}, k_{o p}\right)$ calculated from the data of the replacement series 1 (RS 1) for shoot, grain and grain- $\mathrm{N}$ yields of sole and intercropped pea and oat for 2002 and 2003 with the calculated optimal absolute densities of pea and oat $\left(d_{p o}{ }^{*}: d_{o p}{ }^{*}\right)$, maximum total intercrop yields $\left(Y^{*}\right)$, RYT at maximum total intercrop yield $\left(R Y T_{\max }\right)$ as well as the sole crop yields of pea $\left(\mathrm{Y}_{\mathrm{pp}}\right)$ and oat $\left(\mathrm{Y}_{o o}\right)$.

\begin{tabular}{|c|c|c|c|c|c|c|c|c|}
\hline & & & \multirow{3}{*}{$r$} & & $Y_{p p}$ & \multirow{3}{*}{$\mathrm{RYT}_{\text {max }}$} & \multirow{3}{*}{$\begin{array}{l}d_{p o}{ }^{*}: d_{o p}{ }^{*} \\
\text { [seeds } m^{-2} \text { ] }\end{array}$} & \multirow{3}{*}{$\begin{array}{c}\mathrm{Y}^{\star} \\
{\left[\mathrm{Mg} \mathrm{DM} \mathrm{ha}^{-1}\right.} \\
\left.\mathrm{kg} \mathrm{N} \mathrm{ha}^{-1}\right]\end{array}$} \\
\hline & & & & $k_{p o}$ & $Y_{00}$ & & & \\
\hline & & & & $\mathrm{k}_{\mathrm{op}}$ & $\begin{array}{c}{\left[\mathrm{Mg} \mathrm{DM} \mathrm{ha}^{-1}\right.} \\
\left.\mathrm{kg} \mathrm{N} \mathrm{ha}^{-1}\right]\end{array}$ & & & \\
\hline \multirow{4}{*}{ Shoot } & & pea & $0.99^{\star \star \star}$ & $0.3017^{* *}$ & 8.2 & \multirow{2}{*}{1.09} & \multirow{2}{*}{$59: 78$} & \multirow{2}{*}{9.2} \\
\hline & 2002 & oat & $0.97^{* \star *}$ & $4.7077^{\star}$ & 8.7 & & & \\
\hline & \multirow{2}{*}{2003} & pea & $0.94^{\star \star \star}$ & $0.2463^{*}$ & 8.0 & \multirow{2}{*}{1.20} & \multirow{2}{*}{$64: 60$} & \multirow{2}{*}{10.6} \\
\hline & & oat & $0.98^{* * *}$ & $9.2724^{*}$ & 9.5 & & & \\
\hline \multirow{4}{*}{ Grain } & \multirow{2}{*}{2002} & pea & $0.99^{* \star \star}$ & $0.2947^{* *}$ & 3.8 & \multirow{2}{*}{1.00} & \multirow{2}{*}{$0: 300$} & \multirow{2}{*}{4.1} \\
\hline & & oat & $0.98^{* * *}$ & $3.0167^{* *}$ & 4.1 & & & \\
\hline & \multirow{2}{*}{2003} & pea & $0.94^{* * *}$ & 0.2562 * & 4.4 & \multirow{2}{*}{1.21} & \multirow{2}{*}{$65: 57$} & \multirow{2}{*}{5.7} \\
\hline & & oat & $0.98^{* * *}$ & $9.4363^{*}$ & 5.0 & & & \\
\hline \multirow{4}{*}{$\begin{array}{l}\mathrm{N} \text { in } \\
\text { grain }\end{array}$} & \multirow{2}{*}{2002} & pea & $0.99^{* * *}$ & $0.3204^{* *}$ & 131.6 & \multirow{2}{*}{1.00} & \multirow{2}{*}{$80: 0$} & \multirow{2}{*}{131.6} \\
\hline & & oat & $0.99^{\star \star *}$ & $5.0953^{* *}$ & 66.4 & & & \\
\hline & \multirow{2}{*}{2003} & pea & $0.95^{* \star \star}$ & $0.2631^{*}$ & 146.5 & \multirow{2}{*}{1.38} & \multirow{2}{*}{$75: 18$} & \multirow{2}{*}{169.0} \\
\hline & & oat & $0.98^{\star * \star}$ & $18.8160^{\mathrm{ns}}$ & 93.5 & & & \\
\hline
\end{tabular}

Significance levels for the regressions and the estimations of $\mathrm{k}_{\mathrm{po}}$ and $\mathrm{k}_{\mathrm{op}}$ : significant at $P<0.05,0.01,0.001$ level, respectively; ${ }^{\text {ns }}$ not significant 
Table 3.3

Regression coefficients $(r)$ and crowding coefficients $\left(k_{\text {po }}, k_{o p}\right)$ calculated from the data of the replacement series 2 (RS 2) for shoot, grain and grain- $N$ yields of sole and intercropped pea and oat for 2002 and 2003 with the calculated optimal absolute densities of pea and oat $\left(d_{p_{0}}{ }^{*}: d_{o p}{ }^{*}\right)$, maximum total intercrop yields $\left(Y^{*}\right)$, RYT at maximum total intercrop yield ( $\left.R Y T_{\max }\right)$ as well as the sole crop yields of pea $\left(\mathrm{Y}_{\mathrm{pp}}\right)$ and oat $\left(\mathrm{Y}_{\mathrm{oo}}\right)$.

\begin{tabular}{|c|c|c|c|c|c|c|c|c|}
\hline & & & $r$ & $\begin{array}{l}k_{p o} \\
k_{o p}\end{array}$ & $\begin{array}{c}\mathrm{Y}_{\mathrm{pp}} \\
\mathrm{Y}_{\mathrm{oo}} \\
{\left[\mathrm{Mg} \mathrm{DM} \mathrm{ha}^{-1},\right.} \\
\left.\mathrm{kg} \mathrm{N} \mathrm{ha}^{-1}\right]\end{array}$ & $\mathrm{RYT}_{\max }$ & $\begin{array}{l}d_{p o}{ }^{*}: d_{o p}{ }^{*} \\
\text { [seeds } m^{-2} \text { ] }\end{array}$ & $\begin{array}{c}\mathrm{Y}^{\star} \\
{\left[\mathrm{Mg} \mathrm{DM} \mathrm{ha}^{-1},\right.} \\
\left.\mathrm{kg} \mathrm{N} \mathrm{ha}^{-1}\right]\end{array}$ \\
\hline \multirow{4}{*}{ Shoot } & \multirow[b]{2}{*}{2002} & pea & $1.00^{\star * \star}$ & $0.7156^{\star \star *}$ & 9.3 & \multirow[b]{2}{*}{1.00} & \multirow[b]{2}{*}{$120: 0$} & \multirow[b]{2}{*}{9.3} \\
\hline & & oat & $0.98^{* * *}$ & 1.4292 * & 8.9 & & & \\
\hline & \multirow[b]{2}{*}{2003} & pea & $0.98^{* \star *}$ & $0.4892^{*}$ & 7.7 & \multirow{2}{*}{1.29} & \multirow{2}{*}{$88: 122$} & \multirow{2}{*}{11.1} \\
\hline & & oat & $1.00^{* * *}$ & $6.7254^{* *}$ & 9.4 & & & \\
\hline \multirow{4}{*}{ Grain } & \multirow{2}{*}{2002} & pea & $1.00^{\star \star *}$ & $0.8302^{* \star \star}$ & 4.2 & \multirow{2}{*}{1.00} & \multirow{2}{*}{$0: 450$} & \multirow{2}{*}{4.2} \\
\hline & & oat & $0.99^{\star \star \star}$ & $1.0611^{*}$ & 4.2 & & & \\
\hline & \multirow{2}{*}{2003} & pea & $0.98^{* \star *}$ & $0.4837^{*}$ & 4.1 & \multirow{2}{*}{1.30} & \multirow{2}{*}{$89: 117$} & \multirow{2}{*}{6.0} \\
\hline & & oat & $1.00^{\star \star \star}$ & $7.1858^{\star *}$ & 5.0 & & & \\
\hline \multirow{4}{*}{$\begin{array}{l}\mathrm{N} \text { in } \\
\text { grain }\end{array}$} & \multirow{2}{*}{2002} & pea & $1.00^{\star * *}$ & $0.9139^{* *}$ & 145.6 & \multirow{2}{*}{1.00} & \multirow{2}{*}{$120: 0$} & \multirow{2}{*}{145.6} \\
\hline & & oat & $1.00^{* * *}$ & $2.0533^{* *}$ & 63.4 & & & \\
\hline & \multirow{2}{*}{2003} & pea & $0.99^{\star \star *}$ & $0.4997^{*}$ & 139.3 & \multirow{2}{*}{1.67} & \multirow{2}{*}{$112: 32$} & \multirow{2}{*}{188.9} \\
\hline & & oat & $1.00^{* * *}$ & $49.7782^{n s}$ & 86.0 & & & \\
\hline
\end{tabular}

Significance levels for the regressions and the estimations of $\mathrm{k}_{\mathrm{po}}$ and $\mathrm{k}_{\mathrm{op}}$ : significant at $P<0.05,0.01,0.001$ level; ${ }^{\text {ns }}$ not significant

Crowding coefficients of pea $\left(\mathrm{k}_{\mathrm{po}}\right)$ were significantly lower than those of oat $\left(\mathrm{k}_{\mathrm{op}} ; P=0.0345\right)$, showing the generally lower competitive ability of pea in comparison with oat. Values for $\mathrm{k}_{\mathrm{po}}$ were smaller than 1 , while values for $\mathrm{k}_{\mathrm{op}}$ were consistently greater than 1 (Table 3.2 and 3.3). Averaged over years and yield parameters, crowding coefficients of pea $\left(\mathrm{k}_{\mathrm{po}}\right)$ were 0.2787 for RS 1 and 0.6554 for RS 2, those of oat $\left(\mathrm{k}_{\mathrm{op}}\right) 8.3911$ for RS 1 and 11.3722 for RS 2. The difference between RS 1 and RS 2 was significant for $\mathrm{k}_{\mathrm{po}}(P=0.0023)$, showing an increase in competitive ability of pea with increased density, while oat's competitive ability was not significantly influenced by increased density. $\mathrm{k}_{\mathrm{po}}$ was significantly higher in 2002 than 2003 for both replacement series $(P=$ 0.0343 ), denoting superior competitive ability of pea in 2002. The opposite effect, while not statistically significant $(P=0.0835)$, could be found for oat, where $\mathrm{k}_{\mathrm{op}}$ was lower in 2002 compared with 2003. For RS 1, maximum inter- 
crop yields $\left(\mathrm{Y}^{*}\right)$ exceeded the sole crop yields $\left(\mathrm{Y}_{\mathrm{pp}}, \mathrm{Y}_{\mathrm{oo}}\right)$ only for shoot yield in both years and grain and grain-N yield in 2003 (Table 3.2). Relative yield totals at optimal densities $\left(\mathrm{RYT}_{\max }\right)$ ranged up to 1.38 , which indicates up to $38 \%$ higher yields of the optimal intercrop composition compared with the sole crops. For RS 2, only in 2003 were $\mathrm{RYT}_{\max }>1$ reached (Table 3.3). In 2002, constant final yield was not reached at recommended sole crop density as sole crop yields still increased from $100 \%$ to $150 \%$ of the recommended density. Therefore, intercrops did not exceed the high sole crop yields. However in 2003, increasing sole crop densities led to decreased sole crop yields, so that very high $\mathrm{RYT}_{\max }$ could be predicted for RS 2. Here, the highest $\mathrm{RYT}_{\max }$ of 1.67 was found for grain-N yield in 2003, showing a distinct superiority in $\mathrm{N}$ accumulation of intercrops compared with the sole crops.

This can also be seen from Figure 3.1, which shows the replacement diagrams for the parameter grain-N yield. While in 2002 intercrops did not exceed sole cropped pea, intercrops clearly outyielded both sole crops in 2003. Here, the increased density of RS 2 led to a higher intercropping advantage compared to RS 1 (Figure 3.1c, d). Optimal mixture compositions for maximum $\mathrm{N}$ yields in grain were found for more than $90 \%$ pea in the intercrop, while lower pea densities led to maximum shoot and grain yields, showing that intercropped pea primarily contributed to the $\mathrm{N}$ yield while oat primarily contributed to the amount of biomass. 
- sum of intercrops

- intercropped pea

- intercropped oat
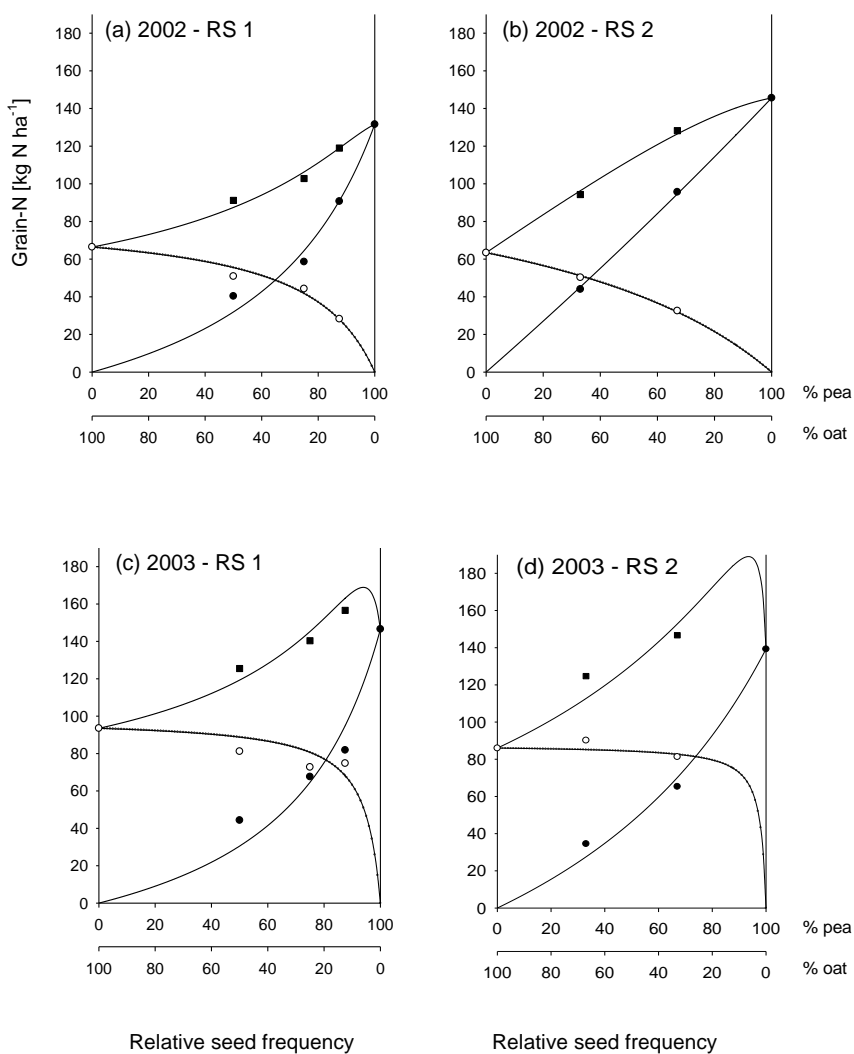

Figure 3.1

Nitrogen accumulated in the grain $\left[\mathrm{kg} \mathrm{N} \mathrm{ha}^{-1}\right]$ of intercropped pea $(\bullet)$, oat $(\circ)$ and the sum of intercropped pea and oat ( $\mathbf{a})$ calculated for replacement series 1 (RS $1 ; a, c)$ and 2 (RS 2; b, d) in 2002 (a, b) and 2003 (c, d). 


\subsubsection{Response surface}

Using field emergence data, regressions and optimizations were done within the rectangular area $\left[1_{\mathrm{p}}=23, \mathrm{u}_{\mathrm{p}}=79\right] \times\left[1_{\mathrm{o}}=20, \mathrm{u}_{\mathrm{o}}=266\right]$ in 2002 and $\left[1_{\mathrm{p}}=24, \mathrm{u}_{\mathrm{p}}=\right.$ $70] \times\left[l_{o}=14, u_{o}=266\right]$ in 2003 . The hyperbolic yield-density equation accounted on average for 53\% (2002) and 88\% (2003) of the variation of pea and $80 \%$ (2002) and 91\% (2003) of the variation of oat (Table 3.4).

Table 3.4

Regression coefficients $(r)$, competition coefficients $\left(b_{0}, b_{1} / b_{0}, b_{2} / b_{0}, c_{0}, c_{1} / c_{0}\right.$ and $c_{2} / c_{0}$ given in $\left.\times 10^{3}\right)$ as well as competitive values $\left(R C=b_{1} / b_{2}, c_{1} / c_{2} ; N D I=\left(b_{1} / b_{2}\right) /\left(c_{2} / c_{1}\right)\right)$ calculated from the hyperbolic yield-density equation fitted to shoot, grain and grain-N yields of intercropped pea and oat for 2002 and 2003 with the calculated optimal absolute densities of pea and oat $\left(d_{p o}{ }^{*}: d_{o p}{ }^{*}\right)$ and maximum total intercrop yields $\left(Y^{*}\right)$.

\begin{tabular}{|c|c|c|c|c|c|c|c|c|c|c|}
\hline & & & $r$ & $\begin{array}{l}\mathrm{b}_{0} \\
\mathrm{c}_{0}\end{array}$ & $\begin{array}{l}\mathrm{b}_{1} / \mathrm{b}_{0} \\
\mathrm{c}_{1} / \mathrm{c}_{0}\end{array}$ & $\begin{array}{l}\mathrm{b}_{2} / \mathrm{b}_{0} \\
\mathrm{c}_{2} / \mathrm{c}_{0}\end{array}$ & $\mathrm{RC}$ & NDI & $\begin{array}{l}d_{p o}{ }^{*}: d_{o p}{ }^{*} \\
\text { [plants } m^{-2} \text { ] }\end{array}$ & $\begin{array}{c}\mathrm{Y}^{*} \\
{\left[\mathrm{Mg} \mathrm{DM} \mathrm{ha}^{-1}\right.} \\
\left.\mathrm{kg} \mathrm{N} \mathrm{ha}^{-1}\right]\end{array}$ \\
\hline \multirow{4}{*}{ Shoot } & \multirow{2}{*}{2002} & pea & $0.59^{* \star *}$ & $64^{* \star *}$ & $16^{* *}$ & $3^{* * *}$ & 4.8 & \multirow{2}{*}{18.3} & \multirow{2}{*}{$79: 181$} & \multirow{2}{*}{9.9} \\
\hline & & oat & $0.90^{* \star *}$ & $21^{\mathrm{ns}}$ & $73^{* * *}$ & $19^{\mathrm{ns}}$ & 3.8 & & & \\
\hline & \multirow[b]{2}{*}{2003} & pea & $0.81^{* * *}$ & $31^{*}$ & $39^{* * *}$ & $15^{* * *}$ & 2.6 & \multirow{2}{*}{9.0} & \multirow{2}{*}{$70: 117$} & \multirow{2}{*}{11.5} \\
\hline & & oat & $0.91^{* * *}$ & $6^{\mathrm{ns}}$ & $187^{* * *}$ & $55^{\mathrm{ns}}$ & 3.4 & & & \\
\hline \multirow{4}{*}{ Grain } & \multirow{2}{*}{2002} & pea & $0.56^{* \star \star}$ & $135^{* \star *}$ & $18^{* \star}$ & $3^{* * *}$ & 6.0 & \multirow{2}{*}{15.6} & \multirow{2}{*}{$79: 238$} & \multirow{2}{*}{4.3} \\
\hline & & oat & $0.86^{* * *}$ & $69^{\mathrm{ns}}$ & $49^{* \star *}$ & $19^{\mathrm{ns}}$ & 2.6 & & & \\
\hline & \multirow{2}{*}{2003} & pea & $0.81^{* * *}$ & $41^{* *}$ & $59^{* * *}$ & $23^{\star \star \star}$ & 2.5 & \multirow{2}{*}{6.9} & \multirow{2}{*}{$70: 104$} & \multirow{2}{*}{5.8} \\
\hline & & oat & $0.89^{* * \star}$ & $3^{\text {ns }}$ & $890^{* \star *}$ & $326^{\mathrm{ns}}$ & 2.7 & & & \\
\hline \multirow{4}{*}{$\begin{array}{l}\mathrm{N} \text { in } \\
\text { grain }\end{array}$} & \multirow{2}{*}{2002} & pea & $0.43^{* *}$ & $4619^{\star \star \star}$ & $12^{\star *}$ & $2^{*}$ & 7.5 & \multirow{2}{*}{20.1} & \multirow{2}{*}{$79: 155$} & \multirow{2}{*}{120.0} \\
\hline & & oat & $0.87^{* * *}$ & $2000^{\text {ns }}$ & $93^{* \star *}$ & $35^{\mathrm{ns}}$ & 2.7 & & & \\
\hline & \multirow{2}{*}{2003} & pea & $0.79^{\star \star \star}$ & $697^{*}$ & $131^{* \star *}$ & $43^{* * *}$ & 3.0 & \multirow{2}{*}{16.0} & \multirow{2}{*}{$70: 51$} & \multirow{2}{*}{148.6} \\
\hline & & oat & $0.93^{* * *}$ & $89^{\mathrm{ns}}$ & $1308^{* \star *}$ & $248^{\mathrm{ns}}$ & 5.3 & & & \\
\hline
\end{tabular}

Significance levels for the regressions and the estimations of $b_{0}, b_{1}, b_{2}, c_{0}, c_{1}, c_{2}$ : significant at $\underline{P}<0.05,0.01,0.001$ levels, respectively; ${ }^{\text {ns }}$ not significant

Regression coefficients for pea were lower than for oat, especially in 2002. Asymptotic single plant yield of oat $\left(\mathrm{c}_{0}\right)$ could not be determined accurately from our data. Nevertheless, the competition coefficients $b_{0}, b_{1}, b_{2}$ and $c_{1}$ could be determined with high accuracy. Of all parameters, only per-plant weight of oat was not significantly influenced by varied pea densities $\left(c_{2}\right)$. Factors other than the presence of pea seemed to have influenced per-plant weights of oat. As perplant weights of both intercrops $\left(1 / \mathrm{b}_{0}, 1 / \mathrm{c}_{0}\right)$ were higher in 2003 compared to 
2002, influence of intra and interspecific competitive stress on single plants of both intercrops was higher in 2003. However in both years, oat was clearly the stronger competitor as oat plants showed on average 9 times stronger intraspecific competitive stress than pea. Over all yield parameters and both intercrops, intraspecific competitive stress was more important than interspecific competitive stress $\left(b_{1}>b_{2}\right.$ and $\left.c_{1}>c_{2}\right) . b_{1}$ was on average 4.4 times higher than $b_{2}$ and $c_{1} 3.4$ times higher than $c_{2}$, describing a high relative competitive ability of both pea and oat (RC; Table 3.4). For pea, relative competitive ability was significantly stronger in 2002 than $2003(P=0.0363)$, so that shoot, grain and grain-N yields of pea were hardly influenced by the presence of oat in 2002, supporting the conclusion that pea preferentially drew back on complementary resources in 2002. In 2003, interspecific competitive stress of pea increased more than intraspecific competition, so that the relative competitive ability of pea was lower in 2003 than 2002, while for oat both intra and interspecific competitive stress increased to the same extent and therefore the relative competitive ability stayed constant. The reduction in relative competitive ability of pea led to increased suppression of pea in 2003 in comparison with 2002. A high degree of resource complementarity was detected, with niche differentiation index values from 7 to 20 (NDI; Table 3.4). In both years, NDI had higher values in 2002 than in 2003 $(P=0.0463)$. Maximum yields were always found at highest pea densities. Lower oat densities had to be chosen to achieve maximum yields in 2003 than in 2002, as the suppressing effect of oat towards pea was higher in 2003. This is seen in Figure 3.2, which shows the response surface for the $\mathrm{N}$ yield in the grain. In 2002, when $\mathrm{N}$ yield in grain of pea was not strongly influenced by increasing oat densities (Figure 3.2a) and oat yield was low (Figure 3.2b), more than $50 \%$ of the recommended sole oat density could be used to reach maximum total yields (Figure 3.2c). In 2003, oat behaved more aggressively towards pea, so the pea curve strongly decreased with increasing oat densities (Figure 3.2d). Here, $\mathrm{N}$ yield in grain of oat was already at low densities on a high level (Figure $3.2 \mathrm{e}$ ), so that increasing oat densities only slightly influenced oat yields positively and $17 \%$ of recommended sole oat density led to maximum total $\mathrm{N}$ yields in the grain (Figure 3.2f). Compared to the recommended sole crop densities, optimal intercrop compositions for all the yield parameters were greater than 100\% (2002: 150\%, 2003: 105\%; means of yield parameters). 

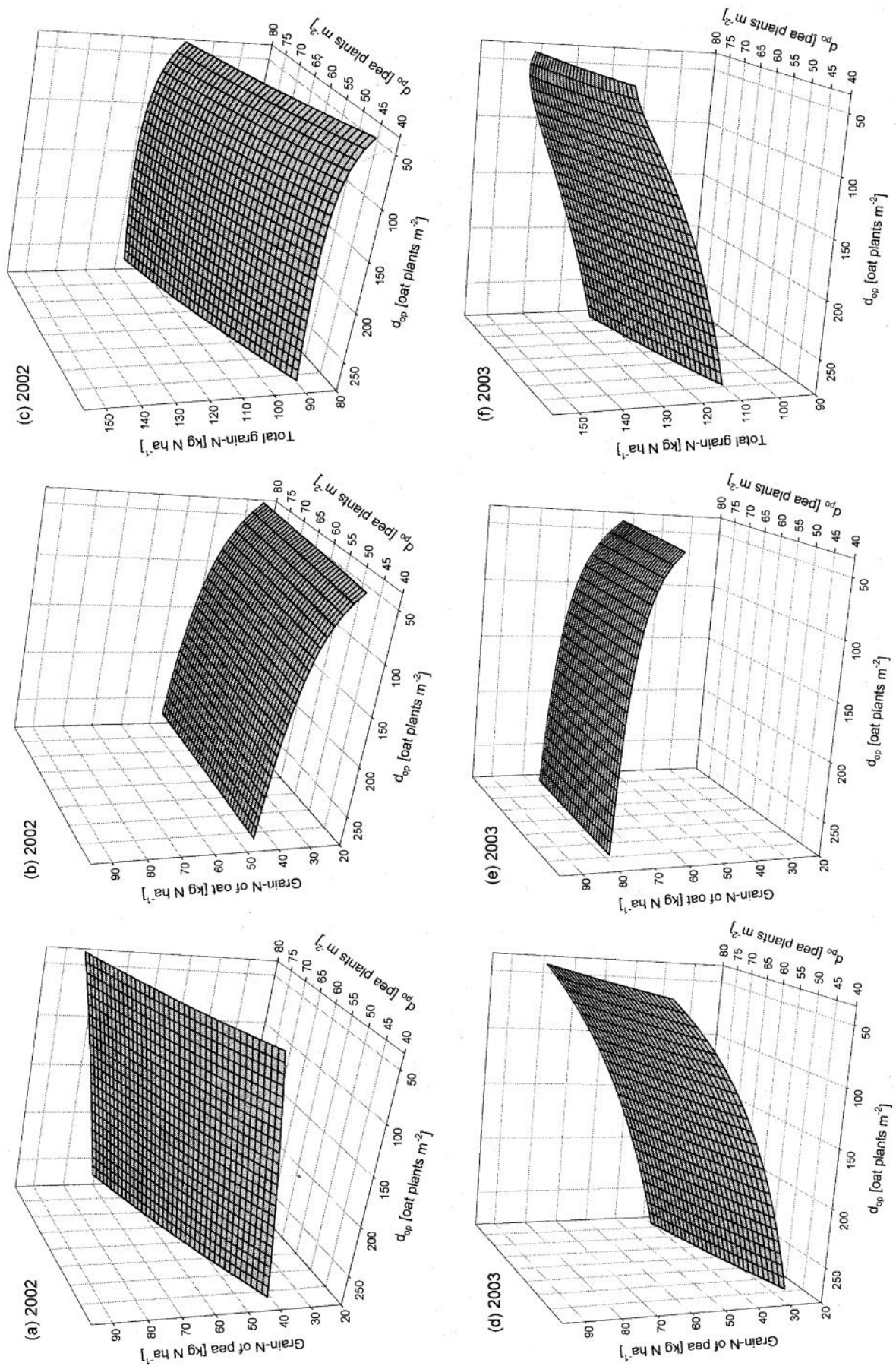

Figure 3.2

Nitrogen accumulated in the grain $\left[\mathrm{kg} \mathrm{N} \mathrm{ha}^{-1}\right]$ of intercropped pea $(\mathrm{a}, \mathrm{d})$, oat $(\mathrm{b}, \mathrm{e})$ and the sum of intercropped pea and oat (c, f) in $2002(a, b, c)$ and $2003(d, e, f)$ calculated with the hyperbolic yield-density equation. 


\subsection{Discussion}

\subsubsection{Competition effects}

Both designs, as well as the field data, came to the same result, that oat was clearly the stronger competitor in the pea-oat intercrop. For the replacement design this was shown by on average 27 times higher competition coefficients of oat $\left(\mathrm{k}_{\mathrm{op}}\right)$ compared to those of pea $\left(\mathrm{k}_{\mathrm{po}}\right)$. This was found for both densities, so that in agreement with Cousens \& O'Neill (1993) we conclude that dominance is hardly influenced by crop density. Rejmanek et al. (1989) found for the replacement series design that with increased density stability of competition indices increased. Nevertheless, only the competitive ability of pea was significantly influenced by density in the present experiment, as $\mathrm{k}_{\mathrm{po}}$ increased with increasing density, while we detected no influence of density on the competitive ability of oat. This agrees with findings by Hauggaard-Nielsen et al. (2006) for pea-barley intercrops, who observed a clear and positive effect of density on the growth of pea, while the effect of density on barley was less straight forward. Due to oat's ability to tiller and thereby compensate for low initial densities, oat is less influenced by a change in planting density than pea.

According to results of the replacement series design, pea was less competitive than oat and therefore suppressed by oat. The response surface design came to the same result, but was able to add the information that the suppression of pea was not primarily caused by the presence of oat but by intraspecific competition. Results from the response surface design indicated for both species that intraspecific competition was stronger than interspecific competition $\left(b_{1}>b_{2}\right.$, $c_{1}>c_{2}$ ) and therefore, that the species used resources complementary. For legume-cereal intercropping, advantages are often presumed to be associated with the complementary use of N sources (Ofori and Stern, 1987; Jensen, 1996). Thereby, intercrop composition influences the complementary resource use. Neumann et al. (2007) showed that the most $\mathrm{N}$ was fixed in the pea dominated intercrops at high cropping densities, while even at low densities intercropped oat completely compensated for the reduced soil-N uptake of intercropped pea.

Competition processes varied depending on growth conditions in the different experimental years. Results from the replacement series design arrived at the conclusion that competitiveness of oat was higher in 2003, when soil-N 
amounts were higher, while at the same time, competitiveness of pea was decreased. The response surface design, however, found that competitiveness of both intercrops increased with higher soil-N content in 2003. This is in accordance with the field data which showed that grain and grain-N yields of both sole crops benefited from the higher soil-N in 2003. However, the rise in competitiveness was higher for intercropped oat than for intercropped pea, so that the relative competitive ability (RC) of intercropped pea decreased. Therefore, yield of intercropped pea was more strongly suppressed by oat at the higher soil-N level. This effect of higher soil-N on competition processes of legumecereal was also observed by Andersen et al. (1983).

\subsubsection{Measurements of resource complementarity}

The two experimental designs show the superiority of intercrops and resource complementarity by values for RYT and NDI larger than 1. Our results show, on average, RYT values of 1.02 (2002) and 1.34 (2003), indicating an advantage of $2 \%$ and $34 \%$ of the intercrops compared to the respective sole crops. The interpretation of the corresponding NDI values of 18.0 (2002) and 10.6 (2003) is more difficult than that of the RYT values, as reference values are hardly available. Helenius and Jokinen (1994) found NDI values of 4.5 for shoot and 4.1 for grain yield of faba bean and oat intercrops. In comparison to these values a higher degree of resource complementarity was measured in the present experiment. In varietal mixtures of rice, Revilla-Monila et al. (2009) measured NDI values of 1.4, which corresponded to a marginal yield advantage. To be able to compare NDI values, more experiments using the hyperbolic yield-density equation and comparisons between different studies are required. The replacement series design and the hyperbolic yield-density equation yield different qualitative conclusions about the influence of years with respect to resource complementarity. While RYT values were higher in 2003 compared to 2002, the opposite effect was found for NDI values. Interpretations of the field data come to the result that the intercrop advantage was higher in $2002 \mathrm{com}$ pared to 2003, which agrees with the results of the response surface design. In 2002, when soil-N content was lower, the pea-oat intercrop could possibly benefit more from complementary resource use, as pea was forced to rely more on $\mathrm{N}_{2}$ fixation, while in 2003, when soil-N content was higher, suppression of 
pea by oat led to reduced $\mathrm{N}_{2}$ fixation and therefore complementary resource use. Other authors (Cowell et al., 1989; Jensen, 1996; Carr et al., 1998; HauggaardNielsen and Jensen, 2001; Schmidtke et al., 2004; Corre-Hellou et al., 2006) have come to the same result, that intercrop advantages of legume-cereal intercrops are reduced at higher soil-N content. Additionally, dry conditions in 2003 could have forced oat to root deeper, so that oat might have been able to benefit from the resources in deeper soil layers. However, the RYT was, due to its dependence on a single total density, incapable of examining this effect. In 2002, when the sole crop densities of pea and oat in the replacement series did not reach constant final yield, intraspecific competition at both densities was obviously not severe enough to let the intercrops benefit from resource complementarity. We assume that intercrop advantages would have been found for the replacement series design if sole crop densities had been increased above the examined densities, as sole crop densities for achieving maximum yields can be increased when intraspecific competition is low (Jokinen, 1991). The inability to show density dependence is a main point of criticism of the RYT (e.g. Connolly, 1986; Inouye, 2001). However, our study confirms that the comparison of different replacement series broadens the knowledge of competition processes achieved by these designs (Firbank and Watkinson, 1985). Additionally, it shows that when planning replacement design studies, it is important that sole crops are sown at high densities, where constant final yield will most certainly be reached. If the density in a replacement series is high enough, the results are likely to be relatively independent of density (Taylor and Aarssen, 1989).

\subsubsection{Optimal intercrop compositions}

It is not surprising that results from the two experimental designs suggest different optimal mixture compositions, as different densities were examined. For the replacement series design, mainly sole crops were responsible for reaching maximum shoot, grain and grain-N yields in 2002, while mixtures with a high amount of pea were optimal in 2003. Therefore, intercrops could only outyield sole crops when sole crop densities reached constant final yield. When constant final yield was reached as in 2003, increased total densities (RS 2) led to higher intercrop advantages. This reinforces the conclusion that densities in mixture 
should be above recommended sole crop densities (Willey, 1979). Especially when a higher $\mathrm{N}$ yield in the grain is desired then the proportion of pea should be high, as pea mainly contributes to the $\mathrm{N}$ yield. This was also shown by the response surface design. Here, optimal densities for reaching maximum yields were always found at the highest pea densities. In combination with the highest pea densities, higher amounts of oat plants in mixture had to be chosen to achieve maximum yields in 2002 compared to 2003. It can therefore be assumed that oat densities for achieving maximum yields should be decreased with increased competitiveness of oat. High competitiveness of oat, e.g. at high densities or high soil-N levels, leads to such a strong suppression of pea that intercrop advantages are reduced. The general conclusion from the present experiment is that the component that shows lowest intraspecific competition can be kept constant at a high density, while that one that is more influenced by intraspecific competition needs to be reduced. This is related to the fact that the partner that shows greater intraspecific interference is also more effective in depressing the yield of the other species (Jolliffe et al., 1984) and therefore has to be reduced. Plant density can compensate for individual plant size (Connolly, 1986) and can therefore be seen as a regulator for specific intercrop objectives (Hauggaard-Nielsen et al., 2006), especially when high $\mathrm{N}$ yields are wanted. However, the results for the optimal intercrop composition depend for both designs on the chosen densities. A good knowledge of the approximate result is therefore essential to be able to choose appropriate densities. The great variation in optimal densities, depending on yield parameters, influence of year and soil-N content, shows that it is not possible to make universally valid predictions from our results.

\subsubsection{Field-use of the experimental designs}

Replacement equations (1a, 1b) provided a good fit for intercropped pea and oat, while the hyperbolic yield density equations ( $3 a, 3 b)$ accounted for less of the variation in the yield of intercropped pea and oat, showing that other factors besides plant density influenced pea and oat per-plant weights, which are not included in the yield-density equation. Estimation of $\mathrm{k}_{\mathrm{op}}$ was less accurate than that of $\mathrm{k}_{\mathrm{po}}$, and $\mathrm{c}_{0}$ was determined less accurate than $\mathrm{b}_{0}$. Both observations may be due to significantly higher plasticity of monocotyledons compared to di- 
cotyledons (Wilson, 1991). Due to oat's ability to tiller, the number of shoots increased strongly when planting density was reduced, leading to a rather density-insensitive yield per area. Wright (1981) reports from mixtures of red clover and Italian ryegrass that $\mathrm{c}_{0}$ could not be significantly determined, especially for the second and third harvest, suggesting that yield per ryegrass plant is close to the asymptote for all densities. However, Wright (1981) found highly significant estimates for $b_{1}$ and $c_{1}$ in agreement with the present experiment. The reaction to intraspecific competition is therefore clearly influential for both intercropped pea and oat per-plant weights. The influence of interspecific competition on single plant weight could be significantly measured for pea, showing the strong influence and high aggressiveness of the non-leguminous partner on the per-plant yields of pea, whereas the influence of pea on oat was less specific. Although the replacement series design is not able to separate intra and interspecific competition (Jolliffe et al., 1984; Inouye, 2001), the present experiment showed that it is advantageous to use more than one mixture within a replacement series, as the resulting replacement diagram enables qualitative interpretations of intraspecific competition processes. When, for example, grain yields of oat do not considerably differ between the densities 12.5, 25 and 50\% in intercrops and are close to grain yields of sole cropped oat (Figure 3.1), strong intraspecific competition for oat can be expected.

All in all, the regressions of equations (3a) and (3b) with field data of intercrops, without the use of monocultures, seem to describe the yield-density relationship reliably and sensibly. This can be seen as beneficial for further field experiments, as the required number of experimental plots is reduced when monocultures can be omitted. The wide range of densities needed for the response surface design was formerly often perceived as prohibitive (Inouye, 2001). Another advantage is that differences in field emergence do not influence the estimates of competition coefficients, as the number of emerged plants instead of the number of targeted plants can be used for the calculation. This reinforces the suitability of the hyperbolic yield-density equation for use in field intercropping experiments, as field experiments carry a high risk of variability in field emergence. Furthermore, the lack of dependence of the response surface design on field emergence makes it extremely suitable for weed-crop studies, where the weed population is hard to influence (Cousens, 1985). However, a high accuracy is needed when counting plants. 
For the experimental design used in this experiment (and various studies of other authors) the dependence of the replacement series design on sole crops very likely led to another inaccuracy. When sole crops are grown with the same row distance as the intercrops sown in alternating rows, fewer plants of the same species are adjacent to each other in one row in sole crops than in intercrops at equal densities. Therefore, sole crops suffered less from intraspecific competition than the intercrops of the same species, even though they were sown at equal densities. Taking the importance of intraspecific competition on the yield of plants into account, sole crop yields would have been lower if row distances had been equal to those in intercrops and consequently higher yield advantages would have been measured. This underlines the importance of considering identical growth conditions for each species when planning replacement series design experiments.

\subsection{Conclusion}

We conclude that varying intercrop compositions can be seen as a regulating mechanism for achieving maximum intercrop yields, especially when intercropping a legume and a non-legume with the aim to increase the grain- $\mathrm{N}$ yield. Both experimental designs, the replacement series and the response surface design, can help finding optimal intercrop compositions, but as resource complementarity in intercrops is responsible for the superiority of the intercrops, examined densities need to be high. Optimal intercrop compositions depend on growing conditions, thus intercropping experiments over a range of different soil and growing conditions as well as varied densities are needed to be able to help farmers and their advisers choosing optimal intercrop compositions. We recommend the use of a response surface design to evaluate field experiments due to its lack of dependence on sole crop densities and total densities. 


\section{Acknowledgements}

This study was supported by the German Research Foundation (Deutsche Forschungsgemeinschaft, DFG). We kindly acknowledge the technical assistance of Christiane Münter, Thomas Seibold and the field staff under the direction of Roland Knöpfel and Helmut Gehrke. Thanks are also due to Irina Bräutigam from Pomor State University Archangelsk for assisting with the conduction of the non-linear regressions and to Mike Wright for proofreading the English text.

\subsection{References}

Andersen, A.J., Haahr, V., Jensen, E.S., Sandfaer, J., 1983. Effect of N-fertilization on yield, protein content and symbiotic N-fixation in Pisum sativum L. grown in pure stand and mixtures with barley. In Perspectives for Peas and Lupins as Protein Crops. Ed. R. Thompson and R. Casey. pp. 205-217. Martinus Nijhoff Publishers, The Hague.

Carr, P.M., Martin, G.B., Caton, J.S., Poland, W.W., 1998. Forage and Nitrogen Yield of BarleyPea and Oat-Pea intercrops. Agron. J. 90, 79-84.

Connolly, J., 1986. On difficulties with replacement-series methodology in mixture experiments. J. Appl. Ecol. 23, 125-137.

Connolly, J., 1987. On the use of response models in mixture experiments. Oecologia, 72, 95-103.

Corre-Hellou, G., Fustec, J., Crozat, Y., 2006. Interspecific competition for soil $\mathrm{N}$ and its interaction with $\mathrm{N}_{2}$ fixation, leaf expansion and crop growth in pea-barley intercrops. Plant Soil 282, 195-208.

Cousens, R., 1985. An empirical model relating crop yield to weed and crop density and a statistical comparison with other models. J. Agric. Sci. Camb. 105, 513-521.

Cousens, R., 1991. Aspects of the Design and Interpretation of Competition (Interference) Experiments. Weed Technology 5, 664-673.

Cousens, R., O’Neill, M., 1993: Density dependence of replacement series experiments. Oikos 66, 347-352.

Cowell, L.E., Bremer, E., Van Kessel, C., 1989. Yield and $\mathrm{N}_{2}$ fixation of pea and lentil as affected by intercropping and $\mathrm{N}$ application. Can. J. Soil Sci. 69, 243-251.

De Wit, C.T., 1960. On competition. Versl. Landbouwk. Onderz. 66.8. Pudoc, Wageningen.

Firbank, L.G., Watkinson, A.R., 1985. On the analysis of competition within two-species mixtures of plants. J. Appl. Ecol. 22, 503-517.

Gliessman, S.R., 2007. Agroecology: the ecology of sustainable food systems. CRC Press, New York, $2^{\text {nd }}$ ed, $205 f f$.

Hauggaard-Nielsen, H., Jensen, E.S., 2001. Evaluating pea and barley cultivars for complementarity in intercropping at different levels of soil $\mathrm{N}$ availability. Field Crops Res. 72, 185-196. 
Hauggaard-Nielsen, H., Andersen, M.K., Jørnsgaard, B., Jensen, E.S., 2006. Density and relative frequency effects on competitive interactions and resource use in pea-barley intercrops. Field Crops Res. 95, 256-267.

Helenius, J., Jokinen, K., 1994. Yield advantage and competition in intercropped oats (Avena sativa L.) and faba bean (Vicia faba L.): Application of the hyperbolic yield-density model. Field Crops Res. 37, 85-94.

Inouye, B.D., 2001. Response surface experimental designs for investigating interspecific competition. Ecol. 82, 2696-2706.

Jensen, E.S., 1996. Grain yield, symbiotic $\mathrm{N}_{2}$ fixation and interspecific competition for inorganic $\mathrm{N}$ in pea-barley intercrops. Plant Soil 182, 25-38.

Jokinen, K., 1991. Assessment of competition and yield advantage in addition series of barley variety mixtures. J. Agric. Sci. Fin. 63, 307-320.

Jolliffe, P.A., Minjas, A.N., Runeckles, V.C., 1984. A Reinterpretation of Yield Relationships in Replacement Series Experiments. J. of Appl. Ecol. 21, 227-243.

Jolliffe, P.A., 2000. The replacement series. J. Ecology 88, 371-385.

Jung, R., 2003. Stickstoff-Fixierleistung von Luzerne (Medicago sativa L.), Rotklee (Trifolium pratense L.) und Persischen Klee (Trifolium resupinatum L.) in Reinsaat und Gemenge mit Poaceen. PhD Thesis, University of Göttingen, Germany.

Law, R., Watkinson, A.R., 1987. Response-surface analysis of two-species competition: An experiment on Phleum arenarium and Vulpia fasciculata. J. Ecology 75, 871-886.

Neumann, A., Schmidtke, K., Rauber, R., 2007. Effects of crop density and tillage system on grain yield and $\mathrm{N}$ uptake from soil and atmosphere of sole and intercropped pea. Field Crops Res. $100,285-293$.

Ofori, F., Stern, W.R., 1987. Cereal-legume intercropping systems. Adv. Agron. 41, 41-90.

Park, S.E., Benjamin, L.R., Watkinson, A.R., 2002. Comparing biological productivity in cropping systems: A competition approach. J. Appl. Ecol. 39, 416-426.

Rejmanek, M., Robinson, G.R., Rejmankova, E., 1989: Weed - crop competition: experimental designs and models for data analysis. Weed Sci. 37, 276-284.

Revilla-Monila, I.M., Bastiaans, L., Van Keulen, H., Kropff, M.J., Hui, F., Castilla, N.P., Mew, T.W., Zhu, Y.Y., Leung, 2009. Does resource complementarity or prevention of lodging contribute to the increased productivity of rice varietal mixtures in Yunnan, China? Field Crops Res. 111, 303-307.

Sackville Hamilton, N.R., 1994. Replacement and additive designs for plant competition studies. J. Appl. Ecol. 31, 599-603.

SAS Institute, Inc., 2000. SAS OnlineDoc, Version 8, Cary, NC: SAS Institute Inc.

Schmidtke, K., Neumann, A., Hof, C., Rauber, R., 2004. Soil and atmospheric nitrogen uptake by lentil (Lens culinaris Medik.) and barley (Hordeum vulgare ssp. nudum L.) as monocrops and intercrops. Field Crops Res. 87, 245-256.

Snaydon, R.W., 1991. Replacement or Additive Designs for Competition Studies? J. Appl. Ecol. 28, 930-946.

Spitters, C.J.T., 1983. An alternative approach to the analysis of mixed cropping experiments. 1.

Estimation of competition effects. Neth. J. agric. Sci. 31, 1-11.

StatSoft, Inc., 2007. Electronic Statistics Textbook. Tulsa, OK: StatSoft. 
Taylor, D.R., Aarssen, L.W., 1989. On the density dependence of replacement-series competition experiments. J. Ecol. 77, 975-988.

Trenbath, B.R., 1978: Models and interpretation of mixture experiments. In: Plant relations in pastures. Ed. J.R.I. Wilson, CSIRO, Melbourne, 145-162.

Van den Bergh, J.P., 1968. Analysis of yields of grasses in mixed and pure stands. Agric. Res. Report 714, Wageningen, 1-71.

Weigelt, A., Jolliffe, P., 2003. Indices of plant competition. J. Ecol. 91, 707-720.

Willey, R.W., 1979. Intercropping - its importance and research needs. Part 1: competition and yield advantages. Field Crop Abstr. 32, 2-10.

Wilson, S.D., 1991. Plasticity, morphology and distribution in twelve lakeshore plants. Oikos 62, 292-298.

Wolfram, S., 2003. The Mathematica Book, 5th ed. Wolfram Media, Cambridge University Press.

Wright, A.J., 1981. The analysis of yield-density relationships in binary mixtures using inverse polynomials. J. Agric. Sci. Camb. 96, 561-567. 



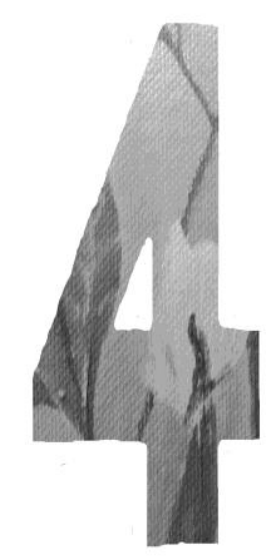

Abschließende Diskussion

\subsection{Aussaatstärke}

Benachbarte Pflanzen beeinflussen sich immer gegenseitig, und zwar unabhängig davon, ob sie zu einer oder verschiedenen Pflanzenarten gehören. Die Konkurrenz innerhalb von Pflanzen einer Art (intraspezifische Konkurrenz) wie auch die zwischen Pflanzen verschiedener Arten (interspezifische Konkurrenz) können sowohl negative als auch positive Auswirkungen auf die Pflanzenentwicklung haben. Die intraspezifische Konkurrenz ist dabei von sehr großer Bedeutung, da die Ansprüche von Pflanzen einer Art in der Regel ähnlich sind und sie um dieselben Ressourcen konkurrieren. Die interspezifische Konkurrenz fällt dagegen oft weniger ins Gewicht als die intraspezifische Konkurrenz, da die Bedürfnisse der Pflanzen hier meist nicht völlig übereinstimmen. Die so entstehende komplementäre Nutzung von Ressourcen kann zu Ertragsvorteilen von Gemengen gegenüber Reinsaaten führen. Insbesondere für Gemenge aus Leguminosen und Getreide werden häufig Ertragsvorteile festgestellt (Willey und Osiru, 1972; Yunusa, 1989; Helenius und Jokinen, 1994; Bulson et al., 1997; Carr et al., 1998), da hier eine komplementäre Nutzung von Stickstoffquellen stattfindet, die auf die Fähigkeit der Leguminose zur atmosphärischen Stickstoff-Fixierung zurückzuführen ist (Tofinga et al., 1993; Jensen, 1996). Die Wahl der Aussaatstärken im Gemenge kann dabei als Stellschraube genutzt 
werden, um eine optimale Nutzung der Ressourcen zu gewährleisten (Hauggaard-Nielsen et al., 2006).

Welche Aussaatstärken in einer Reinsaat zu wählen sind, ohne dass die Einzelpflanzen der untersuchten Art sich untereinander negativ beeinflussen, ist bereits mit hohem Forschungsaufwand und vielfältig untersucht worden (Gliessman, 2007), so dass hier standortangepasste Empfehlungen für alle geläufigen Kulturen existieren. Die Empfehlung optimaler Aussaatstärken von verschiedenen Arten im Gemenge ist dagegen deutlich schwieriger, da hier sowohl intra- als auch interspezifische Konkurrenz beachtet werden müssen. Aufgrund der vielfältigen Variationsmöglichkeiten von zwei oder mehreren Arten ist der Versuchsaufwand im Gemenge gegenüber Reinsaatversuchen ungleich höher. Um den Versuchsaufwand überschaubar zu halten, werden daher in Gemengeversuchen häufig nur die Aussaatstärken eines Gemengepartners variiert oder die Gesamtdichten konstant gehalten. Nur wenige Autoren berichten über Versuche, in denen größere Spektren an Gemengezusammensetzungen untersucht wurden (Yunusa, 1989; Helenius und Jokinen, 1994; Bulson et al., 1997).

\subsubsection{Einfluss der Aussaatstärke auf Ertragsvorteile der Gemenge}

Es ist eine weit verbreitete Vorstellung, dass Ertragsvorteile von Gemengen ausschließlich auf nährstoffarmen Standorten zu erzielen sind (Willey, 1979). Dies kann mit den vorliegenden Ergebnissen aus Feldversuchen mit ErbsenHafer-Gemengen auf einem fruchtbaren Lösslehm-Standort deutlich widerlegt werden. Im Mittel der Aussaatstärken zeigten die untersuchten Gemenge in beiden Untersuchungsjahren bei den Korn- und Sprosserträgen signifikante Ertragsvorteile gegenüber den Erbsen-Reinsaaten sowie bei den Korn-NErträgen gegenüber den Hafer-Reinsaaten. Dabei beeinflusste die Wahl der Aussaatstärke im Gemenge die Höhe der Ertragsvorteile. Höchste Ertragsvorteile bei den Spross- und Kornerträgen erzielten Gemengezusammensetzungen aus hohen Aussaatstärken beider Gemengepartner (70-80 Erbsensamen $\mathrm{m}^{-2}$, 75-300 Haferkörner $\mathrm{m}^{-2}$ ). Die Gesamtdichte der optimalen Gemengezusammensetzungen liegt damit bei über $100 \%$ der empfohlenen Reinsaatdichten. Die Aussaatstärke der Erbse im Gemenge ist dabei sehr hoch, da bei der Erbse im Gemenge bereits ohne Rücknahme der Aussaatstärke ein 
starker Ertragsrückgang gegenüber der Reinsaat zu verzeichnen ist. Die Aussaatstärke des Hafers im Gemenge dagegen kann gegenüber der empfohlenen Reinsaatdichte stärker zurückgenommen werden, da der Hafer aufgrund seiner Fähigkeit zur Bestockung in der Lage ist, geringere Aussaatstärken zu kompensieren. Auch für andere Leguminosen-Getreide-Gemenge wurde beobachtet, dass die Aussaatstärke des Getreides stärker zurückgenommen werden kann als die der Leguminosen, ohne dass es zu hohen Ertragsrückgängen gegenüber den Reinsaaten kommt (Yunusa, 1989; Carr et al., 1998; Hof-Kautz, 2008).

Bei den Korn-N-Erträgen ist die Wahl der Aussaatstärken zum Erreichen hoher Ertragsvorteile wichtiger als bei den Spross- und Kornerträgen. Da die Erbse in erster Linie für den Korn-N-Ertrag im Erntegut des Gemenges verantwortlich ist, ist hier eine deutlich stärkere Reduktion der Haferaussaatstärke (auf 38-75 Haferkörner $\mathrm{m}^{-2}$ ) entscheidend. Dies unterstreicht die Aussage von HauggaardNielsen et al. (2006), dass Aussaatstärken als Regulationsmechanismus für spezifische Ertragsziele, wie z.B. einen hohen N-Ertrag, beim Gemengeanbau dienen können.

Die ermittelten Ertragsvorteile waren im Durchschnitt der Gemenge im Jahr 2002 deutlich höher als im Jahr 2003. Da im Jahr 2002 signifikant geringere

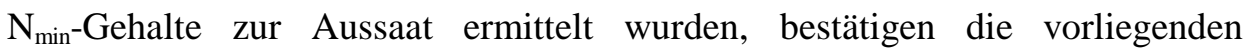
Ergebnisse die Feststellung, dass ein geringeres Boden-N-Angebot die Ertragsvorteile von Leguminosen-Getreide-Gemengen erhöht (Andersen et al., 1983; Ghaley et al., 2005). Dies wird darauf zurückgeführt, dass die Leguminosen bei einem höheren Boden-N-Angebot stärker durch das Getreide unterdrückt werden und somit eine geringere $\mathrm{N}_{2}$-Fixierung aufweisen (Cowell et al., 1989; Jensen, 1996; Hauggaard-Nielsen und Jensen, 2001; Schmidtke et al., 2004; Corre-Hellou et al., 2006). Damit sinkt der Anteil an Leguminosensamen im Erntegut, so dass insbesondere die Korn-N-Erträge der Gemenge von einem höheren Boden-N-Angebot negativ beeinflusst werden (Carr et al., 1998). Die vorliegenden Ergebnisse zeigen jedoch, dass der negative Effekt eines höheren Boden-N-Angebots auf Ertragsvorteile von Erbsen-Hafer-Gemengen durch eine Anpassung der Aussaatstärken abgeschwächt werden kann. Bei höheren $\mathrm{N}_{\text {min }}{ }^{-}$ Gehalten können insgesamt geringere Gesamtdichten gewählt werden. Dabei sollte besonders die Aussaatstärke des konkurrenzkräftigen Hafers stark 
reduziert werden, da die Dominanz des Hafers mit steigendem N-Angebot zunimmt.

Werden die Aussaatstärken im Gemenge in Anlehnung an die Aussaatstärken in Reinsaat gewählt, so unterstellt man, dass Pflanzen sich im Gemenge wie in Reinsaat verhalten (Jolliffe, 2000). Dies ist jedoch nicht der Fall, wie im vorliegenden Versuch daran zu erkennen war, dass die optimalen Pflanzendichten in Reinsaat und Gemenge nicht übereinstimmten, denn optimale Dichten im Gemenge waren immer bei über $100 \%$ der empfohlenen Reinsaatdichten zu finden. Diese Beobachtung zeigt an, dass die beiden Gemengepartner Erbse und Hafer zum Teil auf komplementäre Ressourcen zurückgreifen und vorhandene Ressourcen im Gemenge so besser ausgenutzt werden. Obwohl bereits viele Autoren diese Beobachtung beschrieben haben (z.B. Fisher, 1977; Yunusa, 1989; Bulson et al., 1997; Kübler et al., 2006), ist es in der Gemengeforschung immer noch weit verbreitet, die Gesamtdichte der Gemenge an den Reinsaatstärken zu orientieren (vgl. 4.3).

\subsubsection{Einfluss der Aussaatstärke auf die Qualität des Erntegutes}

Neben den Ertragsvorteilen von Leguminosen-Getreide-Gemengen wird zudem häufig eine Erhöhung der Qualität des Erntegutes festgestellt. So können die Korn-N-Gehalte des Getreides im Gemenge gegenüber der Reinsaat erhöht sein (Jensen, 1986; Tofinga et al., 1993; Bulson et al., 1997; Knudsen et al., 2004; Wichmann et al., 2006; Gooding et al., 2007; Hof-Kautz, 2008; Lauk und Lauk, 2008), und damit die Backqualität des Getreides bzw. die Futterqualität des gesamten Erntegutes verbessert werden.

In der vorliegenden Arbeit konnten ebenfalls erhöhte Korn-N-Gehalte des Hafers festgestellt werden, die auf die reduzierten Kornerträge im Gemenge zurückgeführt werden konnten. Im Gemenge wurde für den Hafer eine negative Korrelation von Kornertrag und Korn-N-Gehalten gefunden. Da diese Korrelation jedoch nicht für die Hafer-Reinsaaten nachgewiesen werden konnte, waren offensichtlich nicht die reduzierten Aussaatstärken, sondern die interspezifische Konkurrenz für den Anstieg der Korn-N-Gehalte im Gemenge mit abnehmenden Kornerträgen verantwortlich. Möglicherweise resultierte dieser Effekt interspezifischer Konkurrenz daraus, dass der Hafer im Gemenge durch 
die Konkurrenz um Boden-N mit der Erbse gezwungen wurde, tiefer zu wurzeln und somit ein höheres N-Angebot als in Reinsaat zur Verfügung hatte. Dass der Hafer im Gemenge auch bei geringen Aussaatstärken in der Lage war, den $\mathrm{N}_{\text {min }}{ }^{-}$ Gehalt des Bodens auch in tieferen Bodenschichten sehr stark abzureichern (vgl. 4.1.4), belegt diese Vermutung. Da die Unterschiede in der Höhe der NAufnahmen von Hafer in Reinsaat und Gemenge jedoch nicht signifikant waren, haben vermutlich weitere Gründe neben der räumlich verschobenen Nutzung von Boden-N zu den erhöhten Korn-N-Gehalten des Hafers im Gemenge geführt. Hof-Kautz (2008) stellte für Gemenge aus Weizen und Wintererbse bzw. Winterackerbohne die These auf, dass neben einer räumlich verschobenen auch eine zeitlich verschobene Nutzung von Boden-N für die erzielte erhöhte Backqualität von Weizen im Gemenge verantwortlich gemacht werden konnte. Aufgrund der interspezifischen Konkurrenz mit Wintererbse bzw. Winterackerbohne stand dem Weizen im Gemenge der Bodenstickstoff möglicherweise erst zu einem späteren Zeitpunkt zur Verfügung, was sich positiv auf die Qualitätsbildung des Weizens auswirkte (Hof-Kautz, 2008). Lauk und Lauk (2008) beobachteten für Erbsen-Hafer-Gemenge eine positive Korrelation von Korn-N-Gehalten des Hafers und Aussaatstärke der Erbse. Dieser Einfluss der Erbsen-Aussaatstärke auf den N-Gehalt des Hafers im Gemenge wurde in der vorliegenden Untersuchung jedoch nicht festgestellt.

Neben erhöhten Korn-N-Gehalten des Hafers im Gemenge zeigten auch die Erbsensamen im Gemenge signifikant höhere N-Gehalte. Diese Beobachtung war auf eine Erhöhung des Stickstoff-Ernteindexes (NHI) von Reinsaat zu Gemenge zurückzuführen. Die Höhe des NHI wurde dabei von der Aussaatstärke des Hafers beeinflusst: je höher die Haferaussaatstärke im Gemenge war, umso stärker stieg der NHI der Erbse an. Dieser Effekt der Haferaussaatstärke auf den NHI der Erbse war im Jahr 2002, in dem die Konkurrenz um Boden-N höher war als im Jahr 2003, am deutlichsten zu beobachten. Eine auf interspezifische Konkurrenz zurückzuführende entsprechend veränderte N-Allokation der Leguminose im Gemengeanbau gegenüber der Reinsaat wurde auch beim Anbau von Linsen im Gemenge mit Nacktgerste festgestellt (Schmidtke et al., 2004). 


\subsubsection{Einfluss der Aussaatstärke auf die $\mathrm{N}_{2}$-Fixierung der Erbse}

Es ist eine typische Beobachtung bei Leguminosen-Getreide-Gemengen, dass die relative $\mathrm{N}_{2}$-Fixierung ( $\mathrm{Ndfa}$ ) der Leguminose von Reinsaat zu Gemenge zwar ansteigt, die absolute Menge an Stickstoff aus der Luft im Spross der Leguminose jedoch sinkt (z.B. Schmidtke et al., 2004; Hauggaard-Nielsen, 2009). Auch die untersuchten Erbsen-Hafer-Gemenge bestätigen diese Beobachtung. Die Aussaatstärken des Hafers im Gemenge beeinflussten die Bedeutung der $\mathrm{N}_{2}$-Fixierung für die Erbse dabei deutlich. Zunehmende Haferaussaatstärken führten zu signifikant ansteigenden Ndfa-Werten, während variierte Erbsenaussaatstärken keinen Einfluss auf die Ndfa-Werte hatten. Erhöhte interspezifische Konkurrenz führte also zu einer Erhöhung des Anteils der $\mathrm{N}_{2^{-}}$ Fixierung an der Stickstoffversorgung der Erbse. Da mit zunehmender interspezifischer Konkurrenz jedoch auch der Sprossertrag der Erbse im Gemenge stark zurückging, nahm hier trotz erhöhter relativer $\mathrm{N}_{2}$-Fixierung die absolute Menge an $\mathrm{N}$ aus der Luft stark ab. Je höher die Aussaatstärken der Erbse und je geringer die Aussaatstärken des Hafers im Gemenge also waren, umso höher waren die absoluten Mengen an N aus der Luft im Spross. Diesen Effekt der Aussaatstärke auf die absolute Menge an fixiertem Stickstoff im LeguminosenGetreide-Gemenge stellten auch Karpenstein-Machan und Stülpnagel (2000) fest. Fan et al. (2006) beobachteten, dass der Sprossertrag der Leguminose einen größeren Einfluss auf die absolute Menge der $\mathrm{N}_{2}$-Fixierung hat als die Höhe der relativen $\mathrm{N}_{2}$-Fixierung, da der Sprossertrag der Leguminose im Gemenge stärker zurückgeht als die relative $\mathrm{N}_{2}$-Fixierung ansteigt. Dies begründet, warum zur Erreichung hoher $\mathrm{N}_{2}$-Fixierleistungen im Gemenge die Erbsenaussaatstärke hoch und die Haferaussaatstärke gering sein sollte, da so höchste Erbsenerträge erzielt werden können.

Die Erbsen im Gemenge aus 80 Erbsensamen $\mathrm{m}^{-2}$ und 38 Haferkörnern $\mathrm{m}^{-2}$ fixierten im Mittel der Jahre und Bodenbearbeitungen mit 79,4 $\mathrm{kg} \mathrm{N}^{-1}$ die höchste Menge an $\mathrm{N}$ aus der Luft. Dies ist gegenüber der entsprechenden Erbsen-Reinsaat ein Rückgang der absoluten Menge an N aus der Luft um 20\%. Bei einer Erhöhung der Haferaussaatstärke auf 150 Körner $\mathrm{m}^{-2}$ stieg dieser Rückgang auf 35\% an. Hauggaard-Nielsen et al. (2009) ermittelten im Mittel über fünf verschiedene europäische Standorte für ein entsprechendes ErbsenGerste-Gemenge aus 100\% Erbse und 50\% Gerste gegenüber der Erbsen- 
Reinsaat nur einen Rückgang um 25\%, was dafür spricht, dass der in der vorliegenden Untersuchung verwendete Hafer (Sorte Alf) ein vergleichsweise hohes interspezifisches Konkurrenzvermögen aufwies. Zur Erhöhung der absoluten Menge an $\mathrm{N}$ aus der Luft im Leguminosen-Getreide-Gemenge ist es also wichtig, das Konkurrenzvermögen des nicht-legumen Gemengepartners bei der Auswahl der Aussaatstärken zu berücksichtigen. Mit steigendem Konkurrenzvermögen des Getreides kann dessen Aussaatstärke im Gemenge stärker reduziert werden.

\subsubsection{Einfluss der Aussaatstärke auf residuale N-Mengen}

Die Verbesserung der Nährstoffeffizienz in der landwirtschaftlichen Produktion ist ein erklärtes Ziel vieler Untersuchungen. Ein Hauptgrund dafür ist, dass unproduktiv genutzte Nährstoffe in der Landwirtschaft zu negativen Beeinträchtigungen von Grund- und Oberflächengewässern führen. Aus Sicht des Umweltschutzes stellt dabei die Auswaschung von Nitrat das größte Problem dar (Blume, 2004). Hierbei stammen 80-90\% des Eintrags aus der Landwirtschaft (Feldwisch und Frede, 1999). Da Nitrat überwiegend während der winterlichen Hauptsickerungsphase ins Grundwasser gelangt, stellt der residuale $\mathrm{N}_{\text {min }}$-Gehalt im Herbst ein wichtiges Kriterium bei der Bewertung von Landnutzungssystemen hinsichtlich ihrer N-Auswaschungsgefährdung dar (Kolbe, 2000).

In der vorliegenden Untersuchung konnten für Erbsen-Hafer-Gemenge residuale $\mathrm{N}_{\text {min }}$-Gehalte in ähnlicher Höhe wie für die Hafer-Reinsaaten festgestellt werden. Damit ist die Gefahr der N-Auswaschung gegenüber der ErbsenReinsaat signifikant reduziert. Aufgrund der schnelleren Jugendentwicklung des Hafers und seines tieferen Wurzelsystems (Hauggaard-Nielsen et al., 2006) könnte abgeleitet werden, dass insbesondere die Aussaatstärke des Hafers einen Einfluss auf die Höhe der $\mathrm{N}_{\min }$-Abreicherung hat. Die vorliegenden Ergebnisse zeigen jedoch, dass auch Gemenge mit hohen Aussaatstärken der Erbse und geringen Aussaatstärken des Hafers ähnlich niedrige residuale $\mathrm{N}_{\text {min }}$-Gehalte wie die Hafer-Reinsaaten aufwiesen. Die Erbse im Gemenge war also in der Lage, geringere Boden-N-Aufnahmen des Hafers in den oberen Bodenschichten zu kompensieren. Der Hafer dagegen wurde im Gemenge möglicherweise gezwungen, tiefer zu wurzeln und konnte so unabhängig von der Aussaatstärke die $\mathrm{N}_{\text {min }}$-Gehalte in den tieferen Bodenschichten abreichern. Somit wurde zusätzlich 
die N-Auswaschungsgefahr aus tieferen Bodenschichten verringert. Dass der Anbau von Gemengen die $\mathrm{N}_{\text {min }}$-Gehalte im Boden und damit die $\mathrm{N}$ Auswaschungsgefahr reduziert, wurde bereits von Zhang und Li (2003) und Whitmore und Schröder (2007) berichtet. Die vorliegende Untersuchung belegt darüber hinaus, dass eine Verringerung der N-Auswaschungsgefahr gegenüber der Erbsen-Reinsaat auch bei einer optimalen Gemengezusammensetzung mit hohen Erbsenaussaatstärken gewährleistet ist.

\subsubsection{Einfluss der Aussaatstärke auf die Konkurrenz um Licht}

Neben der Konkurrenz um Nährstoffe spielt die Konkurrenz um Licht eine entscheidende Rolle in der Entwicklung von Pflanzen (Wilson, 1988). Dementsprechend befasst sich auch die Gemengeforschung mit der Bedeutung der Lichtkonkurrenz für die Vorteile von Gemengen gegenüber Reinsaaten (z.B. Watiki et al., 1993; Lantinga et al., 1999; Berntsen et al., 2004). Es konnte beobachtet werden, dass erhöhte Konkurrenz um Licht im Erbsen-HaferGemenge zu einer geringeren Lichttransmission am Boden und damit zu einer erhöhten Unkrautunterdrückung führen kann (Kimpel-Freund et al., 1998). Die Feststellung einer geringeren Lichttransmission am Boden der Gemenge gegenüber den Reinsaaten führt dabei zu der Vermutung, dass im Gemenge eine effizientere Nutzung der Ressource Licht stattfindet. Diese effizientere Lichtnutzung könnte ebenfalls für Ertragsvorteile des Gemenges verantwortlich sein. Zhang et al. (2008) zeigten für Gemenge aus Weizen und Baumwolle auf, dass die komplementäre Nutzung der Ressource Licht über Zeit und Raum für die hohe Produktivität des Gemenges verantwortlich war.

Die im vorliegenden Versuch durchgeführten Messungen der Lichttransmission am Boden der Reinsaaten und Gemenge (wöchentliche Messungen, Ergebnisse nicht dargestellt) bestätigen die Beobachtung von Kimpel-Freund (1999), dass Erbsen-Hafer-Gemenge ab dem Zeitpunkt der Erbsenblüte geringere Lichttransmissionen aufweisen als beide Reinsaaten. Der Unterschied in der Bodenbeschattung zwischen Hafer-Reinsaat und Gemengen war im vorliegenden Versuch hochsignifikant, so dass eine effizientere Lichtnutzung der Gemenge gegenüber der Hafer-Reinsaat festgestellt werden konnte. Die Aussaatstärke des Hafers hatte dabei weder in Reinsaat noch im Gemenge einen deutlichen Einfluss auf die Lichttransmissionen am Boden, da der Hafer geringe Keim- 
pflanzenzahlen bei geringen Aussaatstärken mit einer stark erhöhten Anzahl von Bestockungstrieben kompensierte. Nur im Jahr 2003, in dem neben höheren $\mathrm{N}_{\text {min }}$-Werten auch deutlich geringere Lichttransmissionen als im Jahr 2002 gemessen wurden, konnten für Reinsaat und Gemenge signifikante Unterschiede zwischen den verschiedenen Haferaussaatstärken festgestellt werden. Die Bodenbeschattung bei höheren Haferaussaatstärken war hier signifikant stärker als bei geringeren Aussaatstärken. Dies bestätigt die Beobachtung von Wilson (1988), dass die Konkurrenz um Licht insbesondere bei hoher Nährstoffverfügbarkeit in den Vordergrund rückt.

Die Aussaatstärken der Erbse hatten in beiden Jahren einen starken Einfluss auf die Lichttransmissionen am Boden der Erbsen-Reinsaaten und Gemenge. Ab dem Zeitpunkt der Erbsenblüte konnte für Reinsaat und Gemenge signifikant stärkere Bodenbeschattungen mit zunehmenden Erbsendichten festgestellt werden. Damit wird die These von Hauggaard-Nielsen et al. (2006) bestätigt, dass das Konkurrenzvermögen der Erbse im späteren Vegetationsverlauf in erster Linie von der Konkurrenz um Licht bestimmt wird. Hauggaard-Nielsen et al. (2006) machen dabei die starke interspezifische Konkurrenz um Licht im späteren Vegetationsverlauf für die in Erbsen-Gerste-Gemenge gefundenen höheren Korn-N-Gehalte der Gerste bei höheren Erbsendichten verantwortlich.

\subsection{Bodenbearbeitung}

Reduzierte Bodenbearbeitung hat zum Ziel, im Vergleich zur konventionellen Bodenbearbeitung mit dem Pflug Zeit und Energie zu sparen, den Boden vor Erosion zu schützen und die Tragfähigkeit des Bodes zu verbessern (Ehlers, 1991; Uri, 1999). Darüber hinaus konnte festgestellt werden, dass der Verzicht auf den Pflug zu einer gesteigerten $\mathrm{N}_{2}$-Fixierung der Erbse führen kann (Matus et al., 1997; Reiter et al., 2002). Dieser Effekt der reduzierten Bodenbearbeitung wird darauf zurückgeführt, dass der Erbse geringere Mengen an Boden-N zur Verfügung stehen, da zum einen insbesondere in den ersten Jahren nach einer Umstellung auf pfluglose Bearbeitung die N-Immobilisierung im Boden überwiegt und zum anderen die N-Mineralisierung zu Vegetationsbeginn häufig verzögert ist (Doran, 1980; Reiter, 2001). Das dadurch verursachte geringere Boden-N-Angebot zwingt die Erbse, stärker auf die $\mathrm{N}_{2}$-Fixierung zurückzu- 
greifen. Außerdem kann reduzierte Bodenbearbeitung die Verfügbarkeit von Bodenwasser erhöhen, was sich ebenfalls positiv auf die $\mathrm{N}_{2}$-Fixierung der Erbse auswirkt (Lafond et al., 1992; Matus et al., 1997). Die $\mathrm{N}_{2}$-Fixierung der Erbse, die eine komplementäre Nutzung von Stickstoffquellen im Erbsen-HaferGemenge ermöglicht, wird als Hauptgrund für die Entstehung von Ertragsvorteilen gegenüber Reinsaaten gesehen. Eine Steigerung der $\mathrm{N}_{2}$-Fixierung der Erbse durch reduzierte Bodenbearbeitung könnte somit mit einer Steigerung der Ertragsvorteile der Gemenge einhergehen.

\subsubsection{Einfluss der Bodenbearbeitung auf Ertragsvorteile der Gemenge}

Die Bodenbearbeitung hatte in der vorliegenden Untersuchung keinen signifikanten Einfluss auf die Kornerträge von Erbse und Hafer in Reinsaat und Gemenge. Festgestellte Unterschiede der Kornerträge von Hafer im Gemenge, nämlich signifikant höhere Kornerträge bei reduzierter Bodenbearbeitung im Jahr 2002, konnten auf einen schlechteren Feldaufgang bei der Pflugvariante zurückgeführt werden, der durch ungünstige Saatablage entstanden war. Durch den lockereren Oberboden der Pflugvariante kam es hier ungeplant zu einer tieferen Ablage der Saat als bei den Varianten der reduzierten Bodenbearbeitung.

Bei den Sprosserträgen der Erbse konnten im Jahr 2002 jedoch Unterschiede zwischen den Bodenbearbeitungen festgestellt werden (Ergebnisse nicht dargestellt). Die Sprosserträge der Erbse im Gemenge waren bei der reduzierten Bodenbearbeitung signifikant geringer als bei der konventionellen Bodenbearbeitung. Dementsprechend waren die Harvestindizes der Erbse im Gemenge bei reduzierter Bodenbearbeitung signifikant erhöht. Für die Erbsen-Reinsaaten war dieser Effekt der Bodenbearbeitung nicht zu beobachten. Die starke interspezifische Konkurrenz durch den Hafer bei reduzierter Bodenbearbeitung bewirkte bei der Erbse offensichtlich eine verstärkte Allokation von Assimilaten ins Korn. 


\subsubsection{Einfluss der Bodenbearbeitung auf die $\mathrm{N}_{2}$-Fixierung der Erbse}

Entgegen den Erwartungen wurde in der vorliegenden Untersuchung die $\mathrm{N}_{2}$-Fixierleistung der Erbse durch reduzierte Bodenbearbeitung nicht gesteigert. Dies ist vermutlich auf ähnlich hohe $\mathrm{N}_{\text {min }}$-Gehalte und N-Mineralisation im Boden bei beiden Bodenbearbeitungsvarianten zurückzuführen. Im Gemenge wies die Erbse sogar in der gepflügt bearbeiteten Variante relativ und absolut höhere $\mathrm{N}_{2}-$ Fixierleistungen auf. Bei ähnlichen Boden-N-Verhältnissen führten also möglicherweise andere Bodeneigenschaften, wie z.B. eine geringere Bodendichte zu verbesserten Konkurrenzbedingungen und $\mathrm{N}_{2}$-Fixierleistungen der Erbse bei konventioneller gegenüber reduzierter Bodenbearbeitung. Die erhöhte Lagerungsdichte bei einer Reduktion der Bodenbearbeitung (Pikul et al., 1993) verursacht erhöhte Eindringungswiderstände, verringertes Porenvolumen und schlechtere Durchlüftung (Khan, 1996). Eine schlechte Durchlüftung des Bodens kann dabei zu einer reduzierten $\mathrm{N}_{2}$-Fixierung führen (Keese et al., 1975). Besonders bei Auftreten extremer Wetterbedingungen, z.B. Trockenheit (Buttery et al., 1998) oder hohe Niederschläge (Lindemann et al., 1982), wie sie in den Versuchsjahren 2002 und 2003 beobachtet wurden, können Verdichtungen die Knöllchenbildung negativ beeinträchtigen. Dadurch könnte die Erbse im Gemenge bei reduzierter Bodenbearbeitung schlechtere Startbedingungen und ein verringertes Konkurrenzvermögen gehabt haben. Diese These kann anhand der vorliegenden Untersuchung jedoch nicht sicher unterlegt werden, da keine Überprüfung der Bodendichte durchgeführt wurde. 


\subsection{Anbaumuster}

In der Gemengeforschung kommen verschiedene Anbaumuster zur Anwendung. Die drei geläufigsten, nämlich das substitutive, additive und „Response Surface"-Anbaumuster sind in Abb. 4.1 schematisch dargestellt. Beim substitutiven Anbaumuster werden im Gemenge gegenüber der Reinsaat nur die Aussaatstärken der einzelnen Gemengepartner variiert, die Gesamtdichte wird jedoch konstant gehalten. Das additive Anbaumuster dagegen hält die Aussaatstärke eines Gemengepartners konstant, während die des anderen und damit die Gesamtdichte variiert wird. Das „Response Surface“-Anbaumuster, welches eine Erweiterung des additiven Anbaumusters darstellt, variiert sowohl die Gesamtdichte als auch die Aussaatstärken beider Gemengepartner unabhängig voneinander, so dass eine große Anzahl unterschiedlicher Gemengezusammensetzungen entsteht, in denen auch die Kombinationen des substitutiven und additiven Anbaumusters enthalten sind.

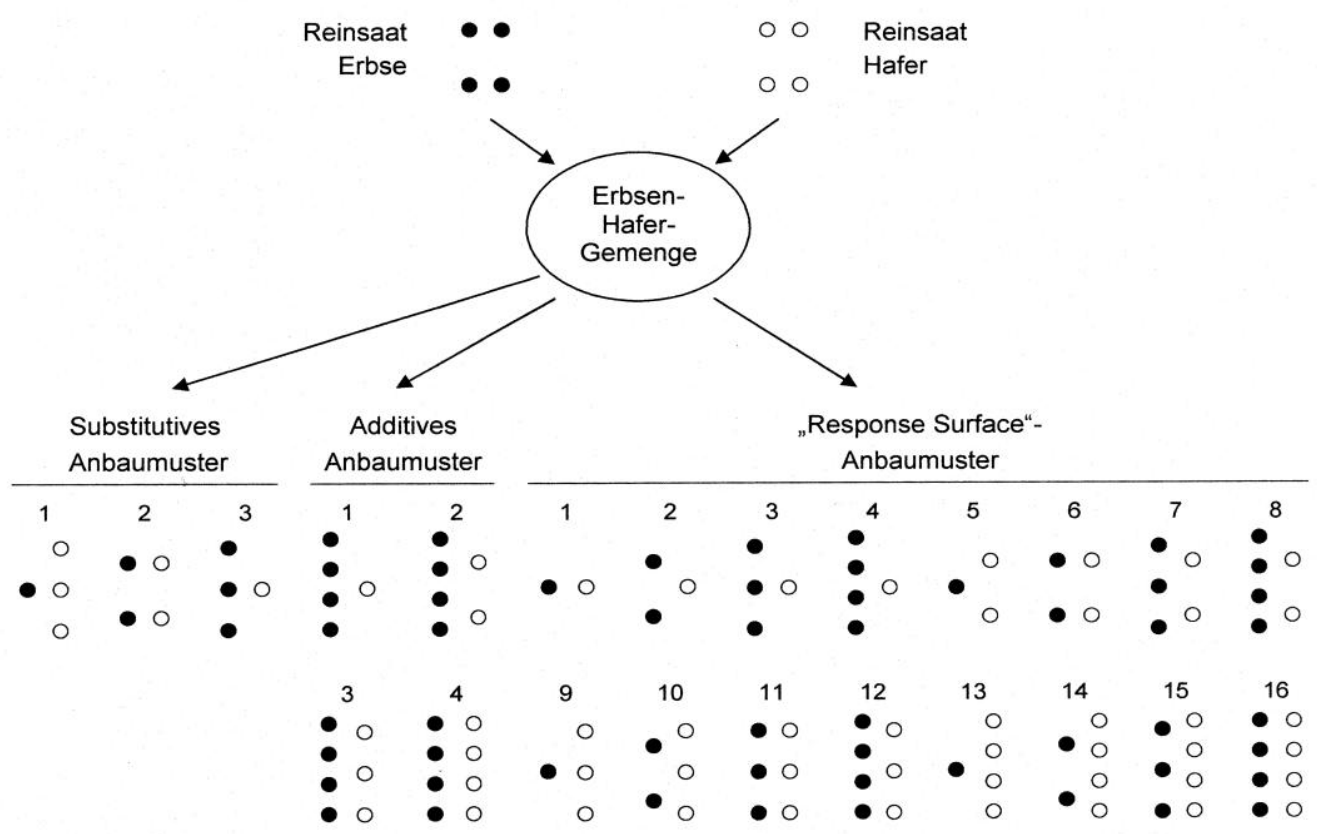

Abb. 4.1

Entstehung der Erbsen-Hafer-Gemenge nach den verschiedenen Anbaumustern ausgehend von den Reinsaaten 
Wie aus Abb. 4.1 deutlich ersichtlich, handelt es sich beim substitutiven Anbaumuster um den geringsten Versuchsaufwand. Zusätzlich wird in der Gemengeforschung aus der in Abb. 4.1 schematisch dargestellten Verdrängungsserie mit drei verschiedenen Gemengezusammensetzungen häufig nur ein einzelnes Gemenge ausgewählt und untersucht, da die Auswertung nach De Wit (1960) auch mit nur einer einzigen Gemengezusammensetzung einer Verdrängungsserie möglich ist. Dabei scheint eine Verallgemeinerung von Ergebnissen zu Konkurrenzverhalten und optimalen Aussaatstärken, die von nur einer einzigen überprüften Gemengezusammensetzung gewonnen wurden, nicht aussagekräftig. Außerdem sind hier die Gemenge immer von den Reinsaatstärken abhängig, so dass es bei unpassender Dichtewahl zu Fehlinterpretationen kommen kann (Law und Watkinson, 1987), da die Untersuchung verschiedener Dichten zu unterschiedlichen Ergebnissen führt (Snaydon, 1991). Aus diesem Grund wurden in der vorliegenden Untersuchung zwei verschiedene Verdrängungsserien, die aus $100 \%$ und $150 \%$ der empfohlenen Reinsaatdichten entstanden, überprüft und miteinander verglichen. Die zahlreichen Kritikpunkte an dem substitutiven Anbaumuster führten zur Erweiterung des additiven Anbaumusters und damit der Etablierung des „Response Surface“-Anbaumusters (Bulson et al., 1997; Park et al., 2002). Wie aus Abb. 4.1 erkennbar handelt es sich beim „Response Surface“-Anbaumuster jedoch um einen im Vergleich zu den beiden anderen Anbaumustern deutlich höheren Versuchsaufwand.

\subsubsection{Ermittlung von Ertragsvorteilen der Gemenge mithilfe der Anbau- muster}

Ertragsvorteile werden beim substitutiven Anbaumuster mit dem „Relative Yield Total“ (RYT) und beim „Response Surface“-Anbaumuster mit dem „Niche Differentiation Index“ (NDI) ermittelt. Liegen die RYT- bzw. NDIWerte $>1$, so liegt ein Ertragsvorteil gegenüber den Reinsaaten vor.

Die in dieser Arbeit ermittelten RYT-Werte unterschieden sich deutlich zwischen den beiden Anbaujahren. Die durchschnittlichen RYT-Werte von 1,02 (2002) und 1,34 (2003) führen zu der Schlussfolgerung, dass der Ertragsvorteil der Gemenge gegenüber den Reinsaaten im Jahr 2003 deutlich höher war als im 
Jahr 2002. Dieser Jahreseffekt wurde durch die im Feldversuch ermittelten Ertragsdaten jedoch nicht bestätigt (vgl. 4.1.1, S. 63), so dass hier eine Missinterpretation des RYT aufgedeckt werden konnte. Da im Jahr 2002 die Erträge der Reinsaaten von Erbse und Hafer von der empfohlenen zur erhöhten Dichte anstiegen, hatte die Ertragsfunktion bei der empfohlenen Aussaatstärke offensichtlich noch kein Maximum erreicht. Damit war die intraspezifische Konkurrenz zu gering, um im Gemenge Ressourcenkomplementarität und damit deutlich sichtbare Ertragsvorteile zu erreichen. Es ist zu vermuten, dass die überprüften Dichten im Jahr 2002 zu gering waren und bei erhöhten Reinsaatdichten stärkere Ertragsvorteile zu finden gewesen wären. Dies wird durch Aussagen von Jokinen (1991) bestätigt, nach denen insbesondere dann höhere Dichten gewählt werden können, wenn die intraspezifische Konkurrenz gering ist. Insgesamt kann aus den vorliegenden Ergebnissen empfohlen werden, bei der Verwendung von Verdrängungsserien Dichten oberhalb der empfohlenen Reinsaatdichten zu wählen. Auch im Jahr 2003 zeigten die Gemenge der dichteren Verdrängungsserie höhere relative Ertragsvorteile als die, die sich an die empfohlene Aussaatstärke anlehnten. RYT-Werte anderer Autoren bestätigen, dass hohe Reinsaatdichten zu höheren Ertragsvorteilen von Gemenge führen (Connolly, 1986; Rejmanek et al., 1989; Taylor und Aarssen, 1989). Dass RYT-Werte aber im höchsten Maße anfällig für Missinterpretationen sind, wie die vorliegende Untersuchung zeigt und bereits von Mead (1979) festgestellt wurde, sollte bei einem Vergleich von RYT-Werten immer im Auge behalten werden.

Die in dieser Arbeit ermittelten durchschnittlichen NDI-Werte von 18,0 (2002) und 10,6 (2003) waren deutlich schwieriger zu interpretieren als die RYTWerte, da es sich hier um einen absoluten Wert und nicht um eine relative Maßzahl handelt. Deshalb ist man auf Vergleichswerte angewiesen, die aber in der Literatur nur vereinzelt zu finden sind (Helenius und Jokinen, 1994; Revilla-Monila et al., 2009). Der qualitative Vergleich der NDI-Werte zwischen den Jahren ermöglicht jedoch im Gegensatz zu den RYT-Werten die mit den Felddaten übereinstimmende Aussage, dass die Ertragsvorteile im Jahr 2002 höher waren als im Jahr 2003. 


\subsubsection{Aussagen über das Konkurrenzgeschehen mithilfe der Anbau- muster}

Die in dieser Arbeit ermittelten Koeffizienten beider Anbaumuster ermöglichten Rückschlüsse auf das Konkurrenzgeschehen in den überprüften Erbsen-HaferGemengen. Der Hafer erwies sich als der deutlich konkurrenzkräftigere Gemengepartner. Das substitutive Anbaumuster zeigte dies mit einem zur Endernte durchschnittlich 27-mal höheren Verdrängungskoeffizienten des Hafers $\left(\mathrm{k}_{\mathrm{op}}\right)$ im Vergleich $\mathrm{zu}$ dem der Erbse $\left(\mathrm{k}_{\mathrm{po}}\right)$. Dies bestätigte sich auch über die beiden Verdrängungsserien, so dass eine von der Dichte unabhängige Dominanz des Hafers festgestellt werden konnte.

Beim „Response Surface“-Anbaumuster wurde für Hafer zur Endernte eine durchschnittlich 10-mal höhere intraspezifische Konkurrenz als für die Erbse ermittelt, was das starke Konkurrenzvermögen des Hafers bestätigt. Die konkurrenzschwächere Erbse litt dabei im Gegensatz zum Hafer weniger unter interspezifischer Konkurrenz, besonders bei den geringeren Boden-N-Gehalten im Jahr 2002, da sie hier zur N-Versorgung auf die $\mathrm{N}_{2}$-Fixierung zurückgreifen konnte, so dass das relative Konkurrenzvermögen der Erbse im Gemenge nur im Jahr 2003 geringer war als das des Hafers. Dass das „Response Surface“Anbaumuster die quantitative Ermittlung intra- und interspezifischer Konkurrenz ermöglicht, ist als großer Vorteil gegenüber dem substitutiven Anbaumuster zu sehen, da so Erkenntnisse über die komplementäre Ressourcennutzung und das Konkurrenzgeschehen gewonnen werden können. So konnte in der vorliegenden Arbeit ermittelt werden, dass durch die erhöhten Boden-N-Gehalte im Jahr 2003 nicht nur das Konkurrenzvermögen des Hafers, sondern auch das der Erbse anstieg. Daraus lässt sich schlussfolgern, dass zur optimalen Ausnutzung der Ressourcen bei hohen Boden-N-Gehalten nicht nur die Aussaatstärke des Hafers, sondern auch die der Erbse reduziert werden kann.

Werden in einer Verdrängungsserie des substitutiven Anbaumusters mehrere Gemengezusammensetzungen überprüft, so lassen sich auch hier qualitative Aussagen über intra- und interspezifische Konkurrenz treffen. Unterscheiden sich z.B. wie in der vorliegenden Untersuchung die ermittelten Kornerträge des Hafers im Gemenge zwischen den Haferaussaatdichten 12,5, 25 und 50\% nicht signifikant und sind auch ähnlich hoch wie die Hafer-Reinsaaterträge bei $100 \%$ Aussaatstärke, so kann die Schlussfolgerung gezogen werden, dass der Hafer 
durch die eigene Art sehr viel stärker beeinflusst wird als durch die benachbarte, die intraspezifische Konkurrenz also hoch ist. Diese Beobachtung führt daher zu der unbedingten Empfehlung, bei der Verwendung des substitutiven Anbaumusters nicht nur eine, sondern mehrere Gemengezusammensetzungen innerhalb einer Verdrängungsserie zu untersuchen.

\subsubsection{Ermittlung optimaler Aussaatstärken im Gemenge mithilfe der Anbaumuster}

Beim substitutiven Anbaumuster ist die Ermittlung des Ertragsmaximums unkompliziert und, da es sich um eine eindimensionale Ertragskurve handelt, sowohl rechnerisch als auch grafisch möglich. Hierbei ist jedoch kritisch zu sehen, dass die Gesamtdichte des maximalen Gemenges systembedingt konstant ist und schon vorher feststeht. Die für eine Untersuchung gewählten Reinsaatdichten sind somit entscheidend für das Ergebnis. Die Optimierung der dreidimensionalen Ertragskurve des „Response Surface“-Anbaumusters, die von der hyperbolischen 3-Parameter-Gleichung nach Wright (1981) beschrieben wird, ist deutlich schwieriger. Sie kommt zu dem Ergebnis, dass hier ein lokales Maximum nicht innerhalb der Fläche der Kurve zu finden ist, sondern auf den Außenkanten des überprüften Dichtebereichs. Damit genügt es, vier eindimensionale Gleichungen zu optimieren, denn die optimale Gemengezusammensetzung kann sich nur bei der höchsten oder niedrigsten Erbsen- bzw. der höchsten oder niedrigsten Haferaussaatstärke befinden. Hier gilt also die entsprechende Kritik wie beim substitutiven Anbaumuster, dass das Ergebnis sehr stark von der Wahl der untersuchten Aussaatstärken abhängig ist. Eine Möglichkeit, diese Kritik zu umgehen, wäre eine manuelle Verschiebung der Außenbereiche innerhalb des überprüften Dichtebereichs, was jedoch ein aufwendiges Verfahren darstellt, da die drei Parameter der Gleichung für jeden veränderten Dichtebereich neu berechnet werden müssten. Für beide Anbaumuster lässt sich deshalb sagen, dass die Kenntnis der ungefähren Größenordnung der optimalen Aussaatstärken im Gemenge bei der Versuchsplanung von Vorteil ist. 


\subsubsection{Anwendung der Anbaumuster in Feldversuchen}

Feldversuche unterliegen im Allgemeinen schwer kontrollierbaren Außeneinflüssen und sind daher störungsanfälliger als Gewächshausversuche. Wright (1981) hat die Entwicklung der hyperbolischen 3-Parameter-Gleichung zunächst mithilfe von Gewächshausversuchen vorgenommen. Die Überprüfung der Eignung für Feldversuche ist jedoch unbedingt notwendig, da eine Übertragung von Ergebnissen aus Gewächshausversuchen auf Feldbedingungen nicht empfehlenswert ist (Ofori et al., 1987). Das substitutive Anbaumuster wurde bereits in zahlreichen Feldversuchen verwendet, jedoch nur wenig hinsichtlich seiner Stärken und Schwächen in Bezug auf variable Bedingungen überprüft.

Im vorliegenden Versuch erreichte der Feldaufgang aufgrund von Mäuse- und Schneckenfraß in keinem Anbaujahr 100\%. Da die Berechnungen im Rahmen des substitutiven Anbaumusters aber auf konstanten Dichten basieren, sind hier die angestrebten anstelle der tatsächlichen Pflanzenzahlen eingeflossen. Die Koeffizienten konnten zwar trotzdem mit großer Genauigkeit bestimmt werden, die Höhe der Koeffizienten ist so aber sicherlich mit Ungenauigkeiten belegt. Beim „Response Surface“-Anbaumuster gingen dagegen die tatsächlichen Pflanzenzahlen in die Berechnungen ein, was für die Verwendung in Feldversuchen positiv zu bewerten ist. Dabei ist jedoch eine hohe Genauigkeit bei der Zählung der Pflanzen erforderlich, deren Aufwand nicht zu unterschätzen ist.

Beide Anbaumuster, das substitutive und das „Response Surface“-Anbaumuster, bestimmten die jeweiligen Konkurrenzkoeffizienten für die Erbse mit höherer Genauigkeit als die für den Hafer. Durch seine hohe Variabilität, die durch die Fähigkeit zur Bestockung verursacht wird, lässt der Hafer sich durch beide Anbaumuster, die auf einer ursprünglichen Körner- bzw. Pflanzenzahl basieren, schwer beschreiben. Wie an der unsicheren Ermittlung des Koeffizienten $c_{2}$ des „Response Surface“-Anbaumusters zu erkennen ist, der den Einfluss interspezifischer Konkurrenz auf den Hafer beschreibt, wurde die Sprossmasse des Hafers im Gemenge nicht nur von der Sprossmasse der Erbse, sondern auch noch von anderen Faktoren beeinflusst. Weigelt et al. (2007) stellten fest, dass die Sprossmasse des Nachbarn zwar einen wichtigen Einfluss auf die Sprossmasse einer Kultur hat, ein großer unerklärter Teil jedoch auf die Wurzelkonkurrenz zurückzuführen ist. 
Die untersuchten Gemenge wurden in alternierenden Reihen angebaut. Da der Reihenabstand sowohl in Reinsaat als auch im Gemenge $12 \mathrm{~cm}$ betrug, bedeutete dies, dass der Reihenabstand zwischen Pflanzen der gleichen Spezies im Gemenge bei $24 \mathrm{~cm}$ lag. Bei gleicher Aussaatstärke einer Spezies befanden sich somit im Gemenge doppelt so viele Pflanzen in einer Reihe wie in Reinsaat. Auch andere Autoren legten bereits auf diese Weise ihre Feldversuche nach dem substitutiven Anbaumuster an (z.B. Izzaurralde et al., 1990; Hauggaard-Nielsen et al., 2009). Abb. 4.1 berücksichtigt diesen Effekt und zeigt anschaulich, dass bei gleicher Aussaatstärke die intraspezifische Konkurrenz im Gemenge so deutlich höher ist als in Reinsaat. Insbesondere beim Hafer führte dieser Effekt im vorliegenden Versuch zu einer deutlich geringeren Bestockung und damit geringeren Einzelpflanzenerträgen im Gemenge gegenüber der Reinsaat. Darum liegt die Vermutung nahe, dass die Reinsaaterträge bei gleichem Ausmaß intraspezifischer Konkurrenz wie im Gemenge geringer ausgefallen wären. Für das substitutive Anbaumuster bedeutet dies, dass höhere RYT-Werte ermittelt worden wären. Bei der Planung von Versuchen, die auf dem Vergleich von Reinsaaten und Gemengen basieren, ist daher von entscheidender Bedeutung, die Standraumverteilung der Einzelpflanzen in Reinsaat und Gemenge gleich zu halten. Das „Response Surface“-Anbaumuster war von diesem Planungsfehler nicht betroffen, da es den Vorteil aufweist, ohne Reinsaaten auszukommen.

Der experimentelle Aufwand von Feldversuchen wird oft als Entscheidungskriterium für oder gegen ein Anbaumuster genannt. Die hohe Anzahl an Versuchsgliedern beim „Response Surface“-Anbaumuster wird dabei immer wieder als abschreckend bezeichnet (Inouye, 2001). Berücksichtigt man jedoch, dass das „Response Surface“-Anbaumuster keine Reinsaaten benötigt und beim substitutiven Anbaumuster mehrere Gemengezusammensetzungen innerhalb einer Verdrängungsserie sowie die Überprüfung verschiedener Verdrängungsserien für optimale Versuchsergebnisse wünschenswert wären, kommt man bei beiden Anbaumustern auf eine ähnlich hohe Anzahl Versuchsglieder. Die Erkenntnisse aus dieser Arbeit unterstützen die Forderung mehrerer Autoren nach größeren Versuchen für aussagekräftige Gemengeforschung (Antonovics und Fowler, 1985; Firbank und Watkinson, 1985; Firbank und Watkinson, 1986; Connolly, 1986; Law und Watkinson, 1987; Finney, 1990). Entscheidend für die Effektivität von Feldversuchen nach beiden Anbaumustern ist dabei, 
dass bereits vor der Versuchsplanung die ungefähre Größenordnung der optimalen Aussaatstärken im Gemenge bekannt ist, da die Ergebnisse beider Anbaumuster stark von der Wahl der überprüften Pflanzendichten beeinflusst werden (vgl. 4.3.3). Da die optimalen Pflanzendichten sehr standortabhängig sind, sind Vorversuche grundsätzlich ratsam.

\subsection{Ausblick}

Die landwirtschaftliche Forschung zielt meistens auf die Verbesserung bestehender Systeme, und dabei insbesondere auf die Erhöhung von Erträgen ab. In der Regel wird hierbei nach einem Maximum innerhalb eines bestehenden Systems gesucht und dabei außer Acht gelassen, dass ein eventuell höheres Maximum in einem ganz anderen System zu finden sein könnte. Diese konservative Sichtweise ist sicherlich ein Grund dafür, dass der Gemengeanbau trotz seiner immer wieder festgestellten, nicht nur auf Ertragsvorteile beschränkten Überlegenheit gegenüber Reinsaaten ein Nischendasein führt.

Die Gemengeforschung steht dabei vor der wichtigen Aufgabe, die vielfältigen Vorteile des Gemengeanbaus stärker hervorzuheben (Anil et al., 1998) sowie vorhandene Gemengesysteme zu verbessern und neue, praxistaugliche und standortangepasste Systeme zu entwickeln. Die Verwendung von Versuchsanlagen, die eine größtmögliche Variation der Gemenge zulassen, ist dabei von großer Wichtigkeit. Das „Response Surface“-Anbaumuster ist dabei von allen in der Gemengeforschung verwendeten Anbaumustern das mit den wenigsten Restriktionen bezüglich der Aussaatstärken und sollte daher stärkere Verwendung finden.

Das substitutive Anbaumuster ist nicht völlig abzulehnen, seine Anwendung und dabei insbesondere die Interpretation des „Relative Yield Total“ sollten jedoch bedacht erfolgen. Die Wahl von Dichten oberhalb der Reinsaatdichten, die Untersuchung mehrerer Gemenge innerhalb einer Verdrängungsserie sowie der Vergleich verschiedener Verdrängungsserien konnten in der vorliegenden Untersuchung die Ergebnisse des substitutiven Anbaumusters stark verbessern. Darüber hinaus setzt die Verwendung des substitutiven Anbaumusters eine sorgfältige Versuchsplanung hinsichtlich identischer Wachstumsbedingungen der Pflanzen in Reinsaat und Gemenge voraus. 
Die untersuchten Erbsen-Hafer-Gemenge zeigten eine sehr starke Konkurrenzfähigkeit des Hafers an. Die Hafersorte Alf neigte zu starker Bestockung, so dass Veränderungen in der Aussaatstärke kaum zu veränderten Erträgen führten. Um die Aussaatstärken im Leguminosen-Getreide-Gemenge als Stellschraube für spezifische Ertragsziele einsetzen zu können, wäre die Nutzung von Getreidearten und -sorten mit geringerer Bestockungsneigung sinnvoll. Insgesamt ist es nicht als vorteilhaft anzusehen, dass die in Gemengen verwendeten Sorten in der Regel hinsichtlich ihrer Leistungen und Eigenschaften in Reinsaat ausgewählt werden, da die Ertragsfähigkeit, die für hohe Reinsaaterträge notwendig ist, in der Regel nicht mit der Ertrags- und Konkurrenzfähigkeit im Gemenge identisch ist (Hill, 1996; Santalla et al., 2001). Die Züchtung von Sorten hinsichtlich einer erhöhten Gemengeeignung, z.B. bezüglich morphologischer Eigenschaften wie Höhe des Hülsenansatzes der Erbse (Bugdahl und Rauber, 2007), wäre hier ein wertvoller Beitrag zur Verbesserung von Gemengesystemen.

Nicht nur die Auswaschung von residualem $\mathrm{N}$ aus der Landwirtschaft stellt ein Gefährdungspotential für die Umwelt dar. Auch wenn der Austrag von Phosphor in Grund- und Oberflächengewässer aus landwirtschaftlich genutzten Böden aufgrund der starken sorptiven Bindung von $\mathrm{P}$ an Boden- und Humuskomplexe mengenmäßig erheblich geringer ausfällt als der von $\mathrm{N}$, ist die Verminderung von P-Verlusten aus der landwirtschaftlich genutzten Böden zunehmend Gegenstand wissenschaftlicher Untersuchungen (Delgado und Scalenghe, 2008), da Phosphor in hohem Maße für die Entstehung eutrophierter Gewässer verantwortlich ist (Correll, 1998). Hauggaard-Nielsen et al. (2009) stellten fest, dass das substitutive Gemenge aus 50\% Erbsen und 50\% Sommergerste gegenüber den jeweiligen Reinsaaten einen um 20\% erhöhten P-Ertrag aufwies (RYT für den P-Ertrag = 1,20). Diese Beobachtung führt zu der Annahme, dass der Gemengeanbau möglicherweise eine pflanzenbauliche Strategie darstellen könnte, die P-Effizienz zu erhöhen und damit P-Verluste auf austragungsgefährdeten Standorten zu reduzieren. Dieser Aspekt verdient durchaus weitere Untersuchung.

Die EU importierte im Jahr 2008 70\% ihres Bedarfs an pflanzlichen Proteinen (Deutscher Bauernverband, 2008). Hauptproteinquelle ist dabei Soja aus den USA und Lateinamerika, und hierbei in zunehmendem Maße gentechnisch 
veränderte Sojasorten. Da ein großer Teil der europäischen Konsumenten Gentechnik ablehnt, steigt die Nachfrage nach europäischen Körnerleguminosen kontinuierlich an. Trotzdem sinkt die Anbaufläche seit 2001 stetig (Ollier und Utz, 2008). Die Gründe, warum europäische Landwirte vor dem Anbau von Körnerleguminosen zurückschrecken sind geringe Preise, niedrige EU-Prämien und starke Ertragsschwankungen. Die Höhe der Ertragsschwankungen kann über den Anbau von Gemengen reduziert werden. Erhöhte Ertragsstabilität wurde bei Umfragen als ein Hauptbeweggrund europäischer Landwirte für den Anbau von Körnerleguminosen im Gemenge genannt (von Fragstein und Niemsdorff et al., 2006). Es muss daher Ziel der Gemengeforschung sein, diesen Vorteil von Leguminosen-Getreide-Gemengen stärker hervorzuheben, da eine Erhöhung des europäischen Körnerleguminosenanbaus hinsichtlich einer nachhaltigen und klimaschonenden Eiweißproduktion sehr zu begrüßen wäre. Die am 29.04.2009 vom Planungsausschuss für Agrar- und Küstenschutz (PLANAK) beschlossene Agrarumweltmaßnahme „Klimaschonender Anbau von Körnerleguminosen" mit einer Förderung von bis zu $220 € /$ ha ist diesbezüglich ein positives politisches Signal und es wäre wünschenswert, wenn die Ausgestaltung der Prämie in den Bundesländern auch den leguminosenbetonten Gemengeanbau vorsehen würde. 


\subsection{Literatur}

Andersen, A.J., Haahr, V., Jensen, E.S., Sandfaer, J., 1983. Effect of N-fertilization on yield, protein content and symbiotic $\mathrm{N}$-fixation in Pisum sativum $\mathrm{L}$. grown in pure stand and mixtures with barley. In: Thompson, R., Casey, R. (Hrsg.): Perspectives for Peas and Lupins as Protein Crops. Nijhoff Publishers, 205-271.

Anil, L., Park, J., Phipps, R.H., Miller, F.A., 1998. Temperate intercropping of cereals for forage: a review of the potential for growth and utilization with particular reference to the UK. Grass Forage Sci. 53, 301-317.

Antonovics, J., Fowler, N.L., 1985. Analysis of frequency and density effects on growth in mixtures of Salvia splendens and Linum grandiflora using hexagonal fan designs. J. Ecol. 73, 219-234.

Berntsen, J., Hauggaard-Nielsen, H., Olesen, J.E., Petersen, B.M., Jensen, E.S., Thomsen, A., 2004. Modelling dry matter production and resource use in intercrops of pea and barley. Field Crops Res. 88, 59-73.

Blume, H.-P., 2004. Handbuch des Bodenschutzes. Verlag ecomed, Landsberg, 3. Auflage, S. 271.

Bugdahl, B., Rauber, R., 2007. Es muss der richtige Partner sein. Land \& Forst 50, 22-24.

Bulson, H.A.J., Snaydon, R.W., Stopes, C.E., 1997. Effects of plant density on intercropped wheat and field beans in an organic farming system. J. Agric. Sci. Camb., 128, 59-71.

Buttery, B.R., Tan, C.S., Drury, C.F., Park, S.J., Armstrong, R.J., Park, K.Y., 1998. The effects of soil compaction, soil moisture and soil type on growth and nodulation of soybean and common bean. Can. J. Plant Sci. 78: 571-576.

Carr, P.M., Martin, G.B., Caton, J.S., Poland, W.W., 1998. Forage and nitrogen yield of barleypea and oat-pea intercrops. Agron. J. 90, 79-84.

Connolly, J., 1986. On difficulties with replacement-series methodology in mixture experiments. J. Appl. Ecol. 23, 125-137.

Corre-Hellou, G., Fustec, J., Crozat, Y., 2006. Interspecific competition for soil $\mathrm{N}$ and its interaction with $\mathrm{N}_{2}$ fixation, leaf expansion and crop growth in pea-barley intercrops. Plant Soil 282, 195-208.

Correll, D.L., 1998. The role of phosphorus in the eutrophication of receiving waters: A review. J. Environ. Qual. 27, 261-266.

Cowell, L.E., Bremer, E., Van Kessel, C., 1989. Yield and $\mathrm{N}_{2}$ fixation of pea and lentil as affected by intercropping and N application. Can. J. Soil Sci. 9, 243-251.

Deutscher Bauernverband, 2008. Europäische Bauernverbände wollen Eiweißpflanzenanbau erhalten - Steigerung der Produktion als echte Herausforderung für Europa. Pressemitteilung vom 27. März 2008.

Delgado, A., Scalenghe, R., 2008. Aspects of phosphorus transfer from soils in Europe. J. Plant Nutr. Soil Sci. 171, 552-575.

De Wit, C.T., 1960. On competition. Versl. Landbouwk. Onderz. 66.8. Pudoc, Wageningen.

Doran, J.W., 1980. Soil microbial and biochemical changes associated with reduced tillage. Soil Sci. Soc. Am. J. 44, 765-771.

Ehlers, W., 1991. Wirkung von Bearbeitungssystemen auf gefügeabhängige Eigenschaften verschiedener Böden. Berichte über die Landwirtschaft, SH 2004, 118-137. 
Fan, F., Zhang, F., Song, Y., Sun, J., Bao, X., Guo, T., Li, L., 2006. Nitrogen fixation of faba bean (Vicia faba L.) interacting with a non-legume in two contrasting intercropping systems. Plant Soil 283, 275-286.

Feldwisch, N., Frede, H.-G., 1999. Stoffeinträge in Gewässer aus der Landwirtschaft. In: Frede, H.-G., Dabbert, S. (Hrsg.). Handbuch zum Gewässerschutz in der Landwirtschaft. Verlag ecomed, Landsberg, 2. Auflage, 4-21.

Finney, D.J., 1990. Intercropping Experiments, Statistical Analysis, and Agricultural Practice. Expl. Agric. 26, 73-81.

Firbank, L.G., Watkinson, A.R., 1985. On the analysis of competition within two-species mixtures of plants. J. Appl. Ecol. 22, 503-517.

Firbank, L.G., Watkinson, A.R., 1986. Modelling the population dynamics of an arable weed and its effects upon crop yield. J. Appl. Ecol. 23, 147-159.

Fisher, N.M., 1977. Studies in mixed cropping. II. Population pressures in maize-bean mixtures. Expl. Agric. 13, 185-191.

Fragstein und Niemsdorff, P. von, Dahlmann, C., Jensen, E.S., Trydemann-Knudsen, M., Crozat, Y., Dibet, A., Monti, M., Pristeri, A., Gooding, M., Ruske, R.E., 2006. Survey in five European countries about intercropping in the farming community. Joint Organic Congress, Odense, Denmark. www.intercrop.dk

Ghaley, B.B., Hauggaard-Nielsen, H., Høgh-Jensen, H., Jensen, E.S., 2005. Intercropping of wheat and pea as influenced by nitrogen fertilization. Nutr. Cycl. Agroecosyst. 73, 201-212.

Gliessman, S.R., 2007. Agroecology: the ecology of sustainable food systems. CRC Press, Boca Raton, 2. Auflage, S. 149.

Gooding, M.J., Kasyanova, E., Ruske, R., Hauggaard-Nielsen, H., Jensen, E.S., Dahlmann, C., von Fragstein, P., Dibet, A., Corre-Hellou, G., Crozat, Y., Pristeri, A., Romeo, M., Monti, M., Launay, M., 2007. Intercropping with pulses to concentrate nitrogen and sulphur in wheat. J. Agric. Sci. 145, 469-479.

Hauggaard-Nielsen, H., Jensen, E.S., 2001. Evaluating pea and barley cultivars for complementarity in intercropping at different levels of soil $\mathrm{N}$ availability. Field Crops Res. 72, 185-196.

Hauggaard-Nielsen, H., Andersen, M.K., Jørnsgaard, B., Jensen, E.S., 2006. Density and relative frequency effects on competitive interactions and resource use in pea-barley intercrops. Field Crops Res. 95, 256-267.

Hauggaard-Nielsen, H., Gooding, M., Ambus, P., Corre-Hellou, G. Crozat, Y., Dahlmann, C., Dibet, A., von Fragstein, P., Pristeri, A., Monti, M., Jensen, E.S., 2009. Pea-barley intercropping for efficient symbiotic $\mathrm{N}_{2}$-fixation, soil $\mathrm{N}$ acquisition and use of other nutrients in European organic cropping systems. Field Crops Res. 113, 64-71.

Helenius, J., Jokinen, K., 1994. Yield advantage and competition in intercropped oats (Avena sativa L.) and faba bean (Vicia faba L.): Application of the hyperbolic yield-density model. Field Crops Res. 37, 85-94.

Hill, J., 1996. Breeding components for mixture performance. Euphytica 92, 135-138.

Hof-Kautz, C., 2008. Ursachen höherer Backqualität von Winterweizen (Triticum aestivum L.) im Gemenge mit Winterackerbohne (Vicia faba L.) oder Wintererbse (Pisum sativum L.).

Dissertation, Georg-August-Universität Göttingen. 
Inouye, B.D., 2001. Response surface experimental designs for investigating interspecific competition. Ecol. 82, 2696-2706.

Izzaurralde, R.C., Juma, N.G., McGill, W.B., 1990. Plant and nitrogen yield of barley-field pea intercrop in cryoboreal-subhumid Central Alberta. Agron. J. 82, 295-301.

Jensen, E.S., 1986. Symbiotic $\mathrm{N}_{2}$ fixation in pea and field bean estimated by ${ }^{15} \mathrm{~N}$ fertilizer dilution in field experiments with barley as reference crop. Plant Soil 92, 3-13.

Jensen, E.S., 1996. Grain yield, symbiotic $\mathrm{N}_{2}$ fixation and interspecific competition for inorganic $\mathrm{N}$ in pea-barley intercrops. Plant Soil 182, 25-38.

Jokinen, K., 1991. Assessment of competition and yield advantage in addition series of barley variety mixtures. J. Agric. Sci. Finl. 63, 307-320.

Jolliffe, P.A., 2000. The replacement series. J. Ecol. 88, 371-385.

Karpenstein-Machan, M., Stülpnagel, R., 2000. Biomass yield and nitrogen fixation of legumes monocropped and intercropped with rye and rotation effects on subsequent maize crop. Plant Soil 218, 215-232.

Keese, C.W., Denton, J.S., Hiller, E.A., Newman, J.S., 1975. Irrigation practices in peanut production in Texas. The Texas Agril. Exp. Sta., U.S.D.A. 9, 42-47.

Khan, A.R., 1996. Influence of tillage on soil aeration. J. Agron. Crop Sci. 177, 253-259.

Kimpel-Freund, H., 1999. Konkurrenz und Unkrautunterdrückung der Erbse (Pisum sativum L.) in Reinsaat und im Gemenge mit Hafer (Avena sativa L.). Dissertation, Georg-AugustUniversität Göttingen.

Kimpel-Freund, H., Schmidtke, K., Rauber, R., 1998. Einfluss von Erbsen (Pisum sativum L.) mit unterschiedlichen morphologischen Merkmalen in Reinsaat und Gemenge mit Hafer (Avena sativa L.) auf die Konkurrenz gegenüber Unkräutern. Pflanzenbauwissenschaften 2, 25-36.

Knudsen, M.T., Hauggaard-Nielsen, H., Jørnsgård, B, Jensen, E.S., 2004. Comparison of interspecific competition and $\mathrm{N}$ use in pea-barley, faba bean-barley and lupin-barley intercrops grown at two temperate locations. J. Agric. Sci. Camb. 142, 617-627.

Kolbe, H., 2000. Landnutzung und Wasserschutz: der Einfluss von Stickstoff-Bilanzierung, $\mathrm{N}_{\text {min }^{-}}$ Untersuchung und Nitratauswaschung sowie Rückschlüsse für die Bewirtschaftung von Wasserschutzgebieten in Deutschland. WLV, Leipzig, 1. Auflage, S. 15.

Kübler, E., Aufhammer, W., Piepho, H.-P., 2006. Mischungseffekte in GetreideKörnerleguminosen-Beständen auf den Kornertrag in Abhängigkeit vom Mischungsverhältnis. Die Bodenkultur 57, 121-130.

Lafond, G.P., Loeppky, H., Derksen, D.A., 1992: The effects of tillage systems and crop rotations on soil water conservation, seedling establishment and crop yield. Can. J. Plant Sci. 72, 103115.

Lantinga, E.A., Nassiri, M., Kropff, M.J., 1999. Modelling and measuring vertical light absorption within grass-clover mixtures. Agric. For. Meteorol. 96, 71-83.

Lauk, R., Lauk, E., 2008. Pea-oat intercrops are superior to pea-wheat and pea-barley intercrops. Acta Agriculturae Scandinavica Section B - Soil and Plant Science 58, 139-144.

Law, R., Watkinson, A.R., 1987. Response-surface analysis of two-species competition: An experiment on Phleum arenarium and Vulpia fasciculata. J. Ecol. 75, 871-886.

Lindemann, W.C., Ham, G.E., Randall, G.W., 1982. Soil compaction effects on soybean nodulation, $\mathrm{N}_{2}\left(\mathrm{C}_{2} \mathrm{H}_{4}\right)$ fixation and seed yield. Agron. J. 74, 307-311. 
Matus A., Derksen, D.A., Walley, F.L., Loeppky, H., Van Kessel, C., 1997. The influence of tillage and crop rotation on nitrogen fixation in lentil and pea. Can. J. Plant Sci. 77, 197-200. Mead, R.,1979. Competition Experiments. Biometrics 35, 41-45.

Ofori, F., J.S. Pate \& W.R. Stern, 1987. Evaluation of $\mathrm{N}_{2}$-Fixation and nitrogen economy of a maize/cowpea intercrop system using ${ }^{15} \mathrm{~N}$ dilution methods. Plant Soil 102, 149-160.

Ollier, C., Utz, H., 2008. Large changes in main crop areas in the EU in 2008. Statistics in Focus, eurostat 59, Luxemburg.

Park, S.E., Benjamin, L.R., Watkinson, A.R., 2002. Comparing biological productivity in cropping systems: A competition approach. J. Appl. Ecol. 39, 416-426.

Pikul, J.L., Ramig, R.E., Wilkins, D.E., 1993. Soil properties and crop yield among four tillage systems in a wheat-pea rotation. Soil Tillage Res. 26, 151-162.

Reiter, K., 2001. Einfluss langjährig differenzierter Bodenbearbeitung auf die $\mathrm{N}_{2}$ Fixierungsleistung von Erbse und Rotklee, ermittelt mit Hilfe einer großflächigen ${ }^{15} \mathrm{~N}$ Spurenanreicherung. Dissertation, Georg-August-Universität Göttingen.

Reiter, K., Schmidtke, K., Rauber, R., 2002. The influence of long-term tillage systems on symbiotic $\mathrm{N}_{2}$ fixation of pea (Pisum sativum L.) and red clover (Trifolium pratense L.). Plant Soil 238, 41-55.

Rejmanek, M., Robinson, G.R., Rejmankova, E., 1989. Weed - crop competition: experimental designs and models for data analysis. Weed Sci. 37, 276-284.

Revilla-Monila, I.M., Bastiaans, L., Van Keulen, H., Kropff, M.J., Hui, F., Castilla, N.P., Mew, T.W., Zhu, Y.Y., Leung, 2009. Does resource complementarity or prevention of lodging contribute to the increased productivity of rice varietal mixtures in Yunnan, China? Field Crops Res. 111, 303-307.

Santalla, M., Rodino, A.P., Casquero, P.A., de Ron, A.M., 2001. Interactions of bush bean intercropped with field and sweet maize. Europ. J. Agron. 15, 185-196.

Schmidtke, K., Neumann, A., Hof, C., Rauber, R., 2004. Soil and atmospheric nitrogen uptake by lentil (Lens culinaris Medik.) and barley (Hordeum vulgare ssp. nudum L.) as monocrops and intercrops. Field Crops Res. 87, 245-256.

Snaydon, R.W., 1991. Replacement or Additive Designs for Competition Studies? J. Appl. Ecol. 28, 930-946.

Taylor, D.R., Aarssen, L.W., 1989. On the density dependence of replacement-series competition experiments. J. Ecol. 77, 975-988.

Tofinga, M.P., Paolini, R., Snaydon, R.W., 1993. A study of root and shoot interactions between cereals and peas in mixture. J. Agric. Sci. 120, 13-24.

Uri, N.D., 1999. Conservation tillage in U.S. agriculture. Environmental, economic, and policy issues. Food Products Press, New York.

Watiki, J.M., Fukai, S., Banda, J.A., Keating, B.A., 1993. Radiation interception and growth of maize/cowpea intercrop as affected by maize plant density and cowpea cultivar. Field Crops Res. 35, 123-133.

Weigelt, A., Schumacher, J., Walther, T., Bartelheimer, M., Steinlein, T., Beyschlag, W., 2007: On the hyperbolic competition model: reply. J. Ecol. 95, 601-602.

Whitmore, A.P., Schröder, J.J., 2007. Intercropping reduces nitrate leaching from under field crops without loss of yield: A modelling study. Europ. J. Agron. 27, 81-88. 
Wichmann, S., Loges, R., Taube, F., 2006. Kornerträge, $\mathrm{N}_{2}$-Fixierleistung und N-Flächenbilanz von Erbsen, Ackerbohnen und Schmalblättrigen Lupinen in Reinsaat und im Gemenge mit Getreide. Pflanzenbauwissenschaften 10, 2-15.

Willey, R.W., 1979. Intercropping - Its importance and research needs. Part 1. Competition and yield advantages. Field Crop Abstr. 32, 2-10.

Willey, R.W., Osiru, D.S.O., 1972. Studies on mixtures of maize and beans (Phaseolus vulgaris) with particular reference to plant population. J. Agric. Sci., Camb., 79, 517-529.

Wilson, J.B., 1988. Shoot and root competition. J. Appl. Ecol. 25, 279-296.

Wright, A.J., 1981. The analysis of yield-density relationships in binary mixtures using inverse polynomials. J. Agric. Sci. Camb. 96, 561-567.

Yunusa, I.A.M., 1989. Effects of planting density and plant arrangement pattern on growth and yields of maize (Zea mays L.) and soya bean (Glycine $\max (\mathrm{L}$.) Merr.) grown in mixtures. J. Agric. Sci. Camb. 112, 1-8.

Zhang, F., Li, L., 2003. Using competitive and facilitative interactions in intercropping systems enhances crop productivity and nutrient-use efficiency. Plant Soil 248, 305-312.

Zhang, L., van der Werft, W., Bastiaans, L., Zhang, S., Li, B., Spiertz, J.H.J., 2008. Light interception and utilization in relay intercrops of wheat and cotton. Field Crops Res. 107, 2942 . 


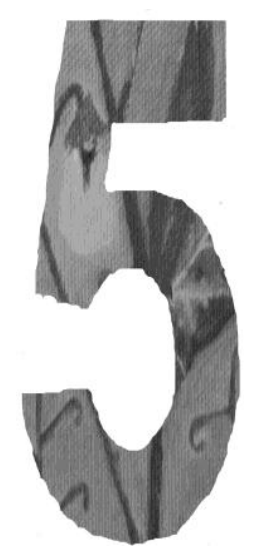

\section{Zusammenfassung / Summary}

\subsection{Zusammenfassung}

In einem zweijährigen Feldversuch (2002/2003) auf einem Auenlehm bei Göttingen wurden verschiedene Aussaatstärken von Erbse und Hafer in Reinsaat und Gemenge auf gepflügten und reduziert bearbeiteten Flächen untersucht. Innerhalb der 16 unterschiedlichen Gemengezusammensetzungen waren zwei verschiedene Verdrängungsserien des substitutiven Anbaumusters enthalten, während alle untersuchten Gemenge dem „Response Surface“-Anbaumuster zugeordnet werden konnten.

\subsubsection{Aussaatstärke}

In beiden Versuchsjahren konnten Ertragsvorteile der Gemenge gegenüber den Reinsaaten festgestellt werden. Dabei zeigte sich deutlich, dass Gemenge mit Aussaatstärken oberhalb der empfohlenen Reinsaatdichten die größten Ertragsvorteile aufwiesen. Dies bedeutet, dass Erbse und Hafer nicht um dieselben Ressourcen konkurrierten und im Gemenge die vorhandenen Ressourcen daher besser ausgenutzt werden konnten als in den Reinsaaten. Die Aussaatstärke der Erbse im Gemenge zur Erreichung maximaler Kornerträge lag bei 87,5-100\% der empfohlenen Reinsaatstärke (70-80 Samen $\mathrm{m}^{-2}$ ). Für Hafer variierte die 
optimale Aussaatstärke im Gemenge je nach $\mathrm{N}_{\min }$-Angebot im Boden: bei niedrigeren $\mathrm{N}_{\min }$-Gehalten konnte der Hafer in höheren Dichten (150-300 Körner $\mathrm{m}^{-2}$ ) als bei höheren $\mathrm{N}_{\min }$-Gehalten (75-150 Körner $\mathrm{m}^{-2}$ ) ausgesät werden. Da für den Korn-N-Ertrag im Erntegut des Gemenges in erster Linie die Erbse verantwortlich ist, konnte zur Erreichung maximaler Korn-N-Erträge die Haferaussaatstärke sogar noch weiter zurückgenommen werden (38-75 Körner $\mathrm{m}^{-2}$ ), während die optimale Aussaatstärke der Erbse hier weiterhin bei $100 \%$ der empfohlenen Reinsaatstärke zu finden war. Je höher die Aussaatstärke der Erbse im Gemenge, umso höher war auch die absolute $\mathrm{N}_{2}$-Fixierleistung. Trotzdem hinterließen die Gemenge mit hohen Erbsenaussaatstärken vergleichbar geringe residuale $\mathrm{N}_{\min }$-Mengen im Boden wie die Hafer-Reinsaaten, so dass durch den Gemengeanbau auch bei hohen Erbsenaussaatstärken die Gefahr der N-Auswaschung gegenüber den Erbsen-Reinsaaten signifikant gesenkt werden konnte. Die Erbse im Gemenge war in der Lage, die reduzierte N-Aufnahme des Hafers bei geringen Haferaussaatstärken in den oberen Bodenschichten zu kompensieren, während der Hafer im Gemenge sehr wahrscheinlich verstärkt die unteren Bodenschichten abreicherte und so zusätzlich die NAuswaschungsgefahr verringerte. Die ertragreichsten Gemenge können somit auch unter Berücksichtigung der Gefahr von N-Auswaschungen im Herbst empfohlen werden.

\subsubsection{Bodenbearbeitung}

Die Bodenbearbeitung hatte kaum Einfluss auf die Erträge und das Konkurrenzgeschehen in den Erbsen-Hafer-Gemengen. Entgegen den Erwartungen wurde auch die $\mathrm{N}_{2}$-Fixierung der Erbse durch die reduzierte Bodenbearbeitung nicht gesteigert. Dies ist auf ähnlich hohe $\mathrm{N}_{\min }$-Gehalte und N-Mineralisation im Boden bei den beiden Bodenbearbeitungsvarianten zurückzuführen. Im Gemenge wies die Erbse in der Pflugvariante sogar höhere $\mathrm{N}_{2}$-Fixierleistungen als in der reduziert bearbeiteten Variante auf. Nicht untersuchte Bodeneigenschaften, wie z.B. eine geringere Bodendichte, könnten hier zu verbesserten Konkurrenzbedingungen und $\mathrm{N}_{2}$-Fixierleistungen der Pflugvariante gegenüber der reduziert bearbeiteten Variante geführt haben. 


\subsubsection{Anbaumuster}

Beide Anbaumuster zeigten gute Anwendbarkeit in Feldversuchen und ließen Rückschlüsse hinsichtlich Konkurrenzgeschehen, Ressourcenkomplementarität und optimaler Aussaatstärken im Gemenge zu. Das „Response Surface“-Anbaumuster zeigte gegenüber dem substitutiven Anbaumuster jedoch den Vorteil, dass es eine Trennung von intra- und interspezifischer Konkurrenz und somit wertvolle Einblicke in das Konkurrenzgeschehen im Erbsen-Hafer-Gemenge ermöglichte. Außerdem ist das „Response Surface“-Anbaumuster unabhängig von Reinsaaten und Gesamtdichten im Gemenge, so dass die tatsächliche Anzahl Pflanzen pro $\mathrm{m}^{2}$ anstatt von angestrebten Pflanzen pro $\mathrm{m}^{2}$ in die Berechnungen einfließen konnte und der unbefriedigende Feldaufgang so nicht zu einer Beeinträchtigung der Ergebnisse führte. Die für das substitutive Anbaumuster ermittelten RYT-Werte zeigten sich nur bedingt aussagekräftig, da sie dichteabhängig sind und somit niedrige Werte z.B. durch zu niedrig gewählte Gesamtdichten entstehen können. Die für das „Response Surface“-Anbaumuster ermittelten NDI-Werte konnten aufgrund kaum vorhandener Vergleichswerte in der Literatur schwer eingeordnet werden. Für beide Anbaumuster können optimale Gemengezusammensetzungen nur innerhalb des überprüften Dichtebereichs festgestellt werden. Darum ist für die Auswahl der zu überprüfenden Aussaatstärken bei der Planung von Feldversuchen nach beiden Anbaumustern die Kenntnis der ungefähren Höhe der optimalen Aussaatstärken im Gemenge von großer Bedeutung. Die vorliegende Untersuchung zeigt, dass der erhöhte Versuchsaufwand bei dem „Response Surface“-Anbaumuster durch den Verzicht auf Reinsaaten reduziert werden kann. Beim substitutiven Anbaumuster dagegen ist eine Erhöhung des Versuchsaufwands, nämlich eine Überprüfung mehrerer Gesamtdichten sowie verschiedener Gemengezusammensetzungen innerhalb einer Verdrängungsserie empfehlenswert. Zusätzlich sollte hier auf identische Wachstumsbedingungen der Kulturen in Reinsaat und Gemenge geachtet werden. 


\subsection{Summary}

In a two-year field experiment (2002/2003) on a loess soil near Göttingen, pea and oat were grown as sole and intercrops at a range of densities. The trial was carried out under conventional and reduced tillage system. Within the 16 examined pea-oat intercrops which followed the response surface design, two different replacement series arose.

\subsubsection{Crop density}

In both years, advantages of the intercrops over sole crops could be measured. Thereby, highest yield advantages were found for intercrops with densities above the recommended sole crop densities. This shows that pea and oat were not competing for exactly the same resources and that intercrops used resources more efficiently than sole crops. To reach maximal grain yields, optimal seed density was $87.5-100 \%$ of recommended sole crop density (70-80 pea seeds $\mathrm{m}^{-2}$ ). Optimal seed density of oat varied depending on soil-N content: at low $\mathrm{N}_{\min }$ values oat could be sown with higher densities (150-300 seeds $\mathrm{m}^{-2}$ ) than at high $\mathrm{N}_{\text {min }}$ values (75-150 seeds $\mathrm{m}^{-2}$ ). As pea is responsible for reaching high grain-N yields in intercrops in the first place, optimal oat density for high grain$\mathrm{N}$ yields could be reduced even further (38-75 seeds $\mathrm{m}^{-2}$ ), while optimal pea density was still $100 \%$ of recommended sole crop density. The higher the pea density in the intercrops, the higher was the amount of $\mathrm{N}$ fixed from atmosphere. However, intercrops with high pea densities showed similar low residual $\mathrm{N}_{\min }$ values as sole cropped oat, so that intercropping significantly reduced the risk of $\mathrm{N}$ losses after harvest compared to sole cropped pea. Intercropped pea at high densities fully compensated for the lower $\mathrm{N}_{\min }$ uptake of oat at lower oat densities. Intercropped oat was possibly forced to take up more soil $\mathrm{N}$ from deeper soil layers and therefore additionally reduced the risk of soil $\mathrm{N}$ losses through leaching from deeper soil layers. So even when taking the risk of soil $\mathrm{N}$ losses into account, highest yielding intercrops could be recommended. 


\subsubsection{Tillage system}

Tillage systems hardly influenced yields and competition processes in pea-oat intercrops. Contrary to expectations, $\mathrm{N}$ uptake from atmosphere by pea was not increased in the reduced tillage system. This can be traced back to similar $\mathrm{N}_{\min }$ values and $\mathrm{N}$ mineralization in the soil under both tillage systems. Intercropped pea under reduced tillage showed even higher $\mathrm{N}_{2}$ fixation compared with conventional tillage. Soil parameters such as e.g. bulk density could have led to a higher competitive ability and $\mathrm{N}_{2}$ fixation of intercropped pea under conventional tillage.

\subsubsection{Experimental design}

Both experimental designs were suited for the use in field experiments and enabled statements about competition processes, resource complementarity and optimal intercropping densities. The response surface design showed the advantage of being able to separate intra and interspecific competition and therefore enabled valuable insights in the competition processes of pea-oat intercrops. Additionally, the response surface design was unaffected by insufficient field emergences, as due to its lack of dependence on sole crops and total densities numbers of plants $\mathrm{m}^{-2}$ instead of seeds $\mathrm{m}^{-2}$ can be used for the evaluation. Due to their density dependence, the determined RYT values had to be interpreted with caution. Low RYT values e.g. emerged from low total densities. Interpretations of the NDI values for the response surface design were difficult as reference values are hardly available. Both experimental designs were only able to find optimal densities within the examined range of densities. Therefore for both experimental designs, knowledge about the approximate scale of the optimal densities of the intercrops is of high importance when planning field experiments. The present experiment was able to show that experimental effort for the response surface design could be reduced, as sole crops could be omitted. However, when using the replacement series design, an investigation of different replacement series as well as different densities within a replacement series can be recommended. It is also very important to consider identical growth conditions for the species in sole and intercrops. 

Lebenslauf

\begin{tabular}{|c|c|}
\hline Personalien & $\begin{array}{l}\text { Angelika Neumann } \\
\text { geboren am 04.02.1974 in Meschede }\end{array}$ \\
\hline \multicolumn{2}{|l|}{ Tätigkeiten } \\
\hline seit 2010 & $\begin{array}{l}\text { Postdoktor, Institut für Boden- und Umweltwissenschaften, } \\
\text { Schwedische Landbauuniversität (SLU), Uppsala/Schweden }\end{array}$ \\
\hline $2007-2009$ & $\begin{array}{l}\text { Lehrkraft für Pflanzenproduktion und Fachenglisch, } \\
\text { Berufliche Schule Rendsburg GTL, Abteilung Landwirtschaft }\end{array}$ \\
\hline $2002-2004$ & $\begin{array}{l}\text { Wissenschaftliche Mitarbeit, } \\
\text { Institut für Pflanzenbau und Pflanzenzüchtung, } \\
\text { Georg-August-Universität Göttingen }\end{array}$ \\
\hline 2001 & $\begin{array}{l}\text { Beratung für ökologischen Landbau, } \\
\text { Naturland-Verband Nord-West, Lippetal-Lippborg }\end{array}$ \\
\hline 2001 & $\begin{array}{l}\text { Beratung für ökologische Produkte, } \\
\text { Ekocentrum, Stockholm/Schweden }\end{array}$ \\
\hline \multicolumn{2}{|l|}{ Ausbildung } \\
\hline $2005-2007$ & $\begin{array}{l}\text { Referendariat für das Lehramt der Sekundarstufe II, } \\
\text { Berufliche Schule Rendsburg GTL, } \\
\text { Abschluss: Zweite Staatsprüfung }\end{array}$ \\
\hline $1997-2001$ & $\begin{array}{l}\text { Hauptstudium der Agrarwissenschaften, } \\
\text { Fachrichtung Pflanzenproduktion, } \\
\text { Georg-August-Universität Göttingen, } \\
\text { Abschluss: Dipl.-Ing. agr. }\end{array}$ \\
\hline $1996-1997$ & $\begin{array}{l}\text { Erasmus-Studium, } \\
\text { Fakultät für Agrar- und Ernährungswissenschaften, } \\
\text { Universität Nottingham/England }\end{array}$ \\
\hline $1994-1996$ & $\begin{array}{l}\text { Grundstudium der Agrarwissenschaften, } \\
\text { Georg-August-Universität Göttingen }\end{array}$ \\
\hline $1993-1994$ & $\begin{array}{l}\text { Landwirtschaftliches Praktikum, } \\
\text { Milchviehtrieb Neitemeier, Meschede-Stesse, } \\
\text { Abschluss: Praktikantenprüfung }\end{array}$ \\
\hline $1984-1993$ & $\begin{array}{l}\text { Städt. Gymnasium Meschede, } \\
\text { Abschluss: Abitur }\end{array}$ \\
\hline $1980-1984$ & Mariengrundschule Meschede \\
\hline
\end{tabular}

